Fish and Fisheries

December 2005; 6(4) : 307-349

http://dx.doi.org/10.1111/j.1467-2979.2005.00199.x

(c) Blackwell Publishing, Inc.
Archimer, archive institutionnelle de l'Ifremer http://www.ifremer.fr/docelec/

The definitive version is available at www.blackwell-synergy.com

\title{
Spatially explicit fisheries simulation models for policy evaluation
}

\author{
Dominique Pelletier* and Stéphanie Mahévas
}

IFREMER BP 21105, 44311 Nantes Cedex 3, France

*: Corresponding author : E-mail: Tel.: (33) 240374164 Fax: (33) 240374075 dominique.pelletier@ifremer.fr

\begin{abstract}
: his paper deals with the design of modelling tools suitable for investigating the consequences of alternative policies on the dynamics of resources and fisheries, such as the evaluation of marine protected areas (MPA). We first review the numerous models that have been developed for this purpose, and compare them from several standpoints: population modelling, exploitation modelling and management measure modelling. We then present a generic fisheries simulation model, Integration of Spatial Information for FISHeries simulation (ISIS-Fish). This spatially explicit model allows quantitative policy screening for fisheries with mixed-species harvests. It may be used to investigate the effects of combined management scenarios including a variety of policies: total allowable catch (TAC), licenses, gear restrictions, MPA, etc. Fisher's response to management may be accounted for by means of decision rules conditioned on population and exploitation parameters. An application to a simple example illustrates the relevance of this kind of tool for policy screening, particularly in the case of mixed fisheries. Finally, the reviewed models and ISIS-Fish are discussed and confronted in the light of the underlying assumptions and model objectives. In the light of this discussion, we identify desirable features for fisheries simulation models aimed at policy evaluation, and particularly MPA evaluation.
\end{abstract}

Keywords: fisher's behaviour, fisheries dynamics, management measures, marine protected areas, mixed fishery, simulation tool, spatially and seasonally explicit model 


\section{Table of contents}

\section{Introduction}

\section{Review of existing models and simulation tools}

2.1. Population and ecosystem modelling

Non spatial models and the efficacy of no-take zones.

Metapopulation models.

Spatially-explicit demographic models.

Multispecific and ecosystem approaches

2.2. Modelling exploitation and management policies

Dynamics of the spatial allocation of fishing effort.

Mixed fisheries

Bioeconomic modelling

Policy modelling and fishers' response to management.

\section{A generic simulation tool for policy evaluation}

3.1. Spatial and seasonal scales in the model

3.2. Population dynamics

3.3. Exploitation

3.4. Relationship between fishing effort and fishing mortality

3.5. Policy modelling and fishers' response to management measures

\section{An illustrative example}

4.1. Fishery parameterization

4.2. Results

\section{Discussion}

5.1. Which ecological model for MPA evaluation?

5.2. Exploitation and management modelling

5.3. What kind of tool is needed for policy screening? 


\section{Introduction}

Quantitative assessment of the consequences of policy options on resources and exploitation is necessary for stock assessment and fisheries management. This is indispensable to obtain diagnostics about current exploitation and management schemes, and to assess the impact of alternative policies on performance of a fishery.

This is generally achieved by modelling the dynamics of fisheries, including resources and exploitation. Many models have concentrated on resource modelling, and the adoption of the Ecosystem Approach to Fisheries favoured the development of models focused on trophic interactions between species. Conversely, models describing the interactions between resources, fleets and management have been given much less attention. Yet, these interactions are also regarded as key issues for understanding fisheries dynamics (Salas and Gaertner 2004), and for overcoming many fisheries management failures (Hilborn 2004).

Whatever the focus of the model, most fisheries models, including those used in stock assessments, are too complex to be analysed using existing mathematical techniques. For instance, beyond dimension two (e.g. two groups in a stage-structured model), mathematical techniques are either too complex or not yet developed, and analytical results are scarce (Doubleday 1975; Goh 1977; Levin and Goodyear 1980; Verdoit-Jarraya 2003). Thus fisheries dynamics are in general studied through simulation models.

In fisheries models, complexity first arises from age or length structures, which have been included in models for a long time (Beverton and Holt 1957; Jones 1961). A more recent step toward complexity lies in spatially-explicit models. Spatial heterogeneities in population and exploitation dynamics, and even more the dependence between these two processes, makes this type of model almost indispensable to get an accurate picture of fisheries dynamics. The failure to account for such patterns has been a suspected cause of certain biases in stock assessment, e.g. illustrated by retrospective patterns (see e.g. the case of western Channel sole in Anonymous (1991). For instance, Pelletier et al. (unpublished findings ${ }^{1}$ ) evaluated biases in CPUE-based abundance indices resulting from the preferential allocation of fishing

\footnotetext{
${ }^{1}$ Pelletier, D., Parma, A.M., and Sullivan, P.J. (1993) Combining different sources of information in estimating abundance maps for exploited fish populations. Session on "Recent developments in the quantitative analysis of fisheries data". Symposium of the American Fisheries Society, Portland, August 1993.
} 
Accepted for publication in Fish and Fisheries

effort in high abundance areas. In addition to a better appraisal of fisheries dynamics, spatially-explicit models are more appropriate for exploring spatial management measures like Marine Protected Areas (MPA). In the last decade, MPA have more and more been advocated as a promising management measure for restoring resources and protecting ecosystems (Agardy 1994; Sumaila et al. 2000). In parallel, a growing body of literature has been devoted to the question and many research projects are undertaken. The term MPA is here taken in the wider sense of any restriction to fishing that is limited in space (and possibly in time), which is close to the official IUCN definition (Kelleher and Kenchington 1992) of "any area of intertidal or subtidal terrain, together with its overlying water and associated flora, fauna, historical and cultural features, which has been reserved by law or other effective means to protect part or all of the enclosed environment". This definition is more general than the widely-used term « marine reserve » which often designates an area where fishing is totally and permanently prohibited (also called no-take zone). In the following, reserve means no-take zone.

Beside age (or length) and spatial structure, additional complexity in fisheries models may arise from seasonal structure. The vast majority of models ignores seasonal variations, which are nevertheless necesssary to depict large-scale spatial distributions linked with the life cycle of exploited populations (see examples in Ogden and Quinn (1984) and Rowley (1994)). Seasonal variations in resource distribution result in seasonal patterns in fishing effort allocation (Ogden and Quinn 1984; Whitmarsh 1985; Vignaux 1996b; Hall et al. 1988 ; Poulard and Léauté 2002).

A last and important reason for complexity in fisheries models lies in multispecies multifleet aspects in mixed fisheries. Mixed fisheries exploit a number of species (multispecies) either simultaneously or sequentially using distinct gears and carrying out different types of fishing activity (multifleets), depending on the time of the year. This results in so-called technical interactions (Laurec et al. 1991) that make it difficult to evaluate the dynamics of both resources and fishing activities. The diversities of fishing activities, associated catch levels and catch compositions, arise from the variety of fishing grounds exploited, the species targetted and the gears used, but also from other factors like fishers' behaviour, economic considerations or environmental conditions. Mixed fisheries form the majority of demersal and benthic fisheries over the world. Mixed fisheries models must include additional details to capture the diversity of fishing activities and exploited resources. 
Accepted for publication in Fish and Fisheries

In this paper, we first review simulation models developed for investigating fisheries dynamics. We focus on models aimed at policy evaluation. Models are compared in terms of underlying hypotheses and results. In particular, we compare their respective suitabilities to evaluating the impact of MPAs on fisheries dynamics. Unlike review papers on MPA modelling (Guénette et al. 1998; Sumaila et al. 2000; Gerber et al. 2003), we address modelling issues in both population and exploitation components, and we deal with MPA in general, not only no-take zones. In a second step, we present a simulation model we developed for mixed fisheries, and we show how it can address some of the issues raised in the review. We finally discuss the abilities of existing models to evaluate policies, and point out desirable features for such policy-screening tools.

Because we focus on MPA and mixed fisheries, the review concentrates on models of demersal and benthic populations, pelagic fisheries being in general described at other spatial scales and using distinct modelling approaches.

\section{Review of existing models and simulation tools}

In this section, we review the ingredients of simulation models aimed at exploring the impact of policies on fisheries dynamics, and particularly MPA. We successively examine population and ecosystem modelling, and exploitation modelling.

\subsection{Population and ecosystem modelling}

Many different models have been developed for fisheries simulation. For each kind of model, we relate the assumptions and model features to the MPA designs that can be investigated, and to the results obtained from the models. Models are presented according to increasing complexity. 
Accepted for publication in Fish and Fisheries

Non spatial models and the efficacy of no-take zones. The simplest population models used to evaluate the impact of MPA were not spatially explicit (Table 1). They were aimed at testing no-take zones and were mainly used to investigate the impact of reserve size on biological reference points, like Maximum Sustainable Yield (MSY) or the ratio of current biomass to virgin biomass (see e.g. Mace 1994). Most often, no regulation of fishing was considered aside from the no-take zone. Consequently, the reserve size required to ensure population sustainability is high and reallocation of fishing effort in the open area may induce undesirable effects (Table 2). But population equilibrium may be reached for an infinity of combinations of exploitation rates and reserve size, which shows that both regulations should be considered jointly (Mangel 1998). When the exploitation rate is stochastic, optimal reserve size may be calculated for a given risk to the population (Mangel 2000a).

Metapopulation models. Models derived from metapopulation theory (Hanski and Gilpin 1997) have also been used to evaluate the impact of no-take zones on the dynamics of exploited populations. Patch occupancy models (Levins 1970) depict the dynamics of a large number of habitat patches connected via migration, and population size is described through the proportion of patches occupied by fish, rather than by biomass or abundance. Mortality is included in the extinction rate of patches. Using this kind of model, Man et al. (1995) showed that a no-take zone allows maximization of both catch and stock size if the exploitation rate is high. Depending on the exploitation rate, the proportion of no-take zone that simultaneously achieves maximum catch and stock size ranges between 0 and 0.5 . This type of model assumes all patches are identical, and ignores the spatial arrangement of patches and populations, as well as the local dynamics of populations; which limits their interest for evaluation of MPA and other policies. Reserve impact was more often studied through source-sink and metapopulation models (Table 1), which allows exploring the consequences of alternative reserve locations. All papers emphasize the importance of establishing reserves in source patches (Table 2). Sanchirico and Wilen (2001b) mathematically demonstrated that in this case, both biomass and yield increased if dispersal rates were moderate and if the source patch was productive. Conversely, placing a reserve in sink patches may induce negative effects. Upon reserve establishment, fishing effort must be reduced to prevent harmful consequences of effort displacement toward open patches. 
Accepted for publication in Fish and Fisheries

Metapopulation models including a larval pool (e.g. appropriate for benthic invertebrates and reef fish with pelagic larvae (Carr and Reed 1992)) yield similar results, showing that persistence requires protection of source populations from excessive fishing pressure (Tuck and Possingham 1994, 2000; Supriatna and Possingham 1998). The allocation of fishing effort that permits population persistence may then be determined as a function of local reproduction success and subpopulation connectivity. An appropriate reserve location is all the more crucial when fishing pressure is high, reserve is small, and habitat is not fully suitable for populations. For several hypotheses about dispersal processes (Sanchirico and Wilen (1999, 2001a and b), Table 1), creation of a reserve from the initial equilibrium situation always increases total biomass. Harvest may increase provided certain conditions are met, if reserve is established in a source, or under the assumption of density-dependent dispersal. These conditions include low initial biomasses (i.e. overexploitation) and an intermediate dispersal rate.

Compared to non spatial models, metapopulations models allow the exploration of a wider range of questions related to evaluation of reserve impact, in particular, reserve location and the issue of Single Large Or Several Small (SLOSS) reserves (Simberloff 1988). For instance, Hastings and Botsford (2003) showed that conservation and maximisation of fisheries yields were attained for different reserve designs in terms of overall size of reserve network and reserve number. Conversely, metapopulation models were rarely used to investigate reserve size (but see Crowder et al. 2000). Although they provide useful general results with regard to reserve impact and spatial allocation of fishing effort, such approaches may not be fully suitable for evaluating the consequences of MPA on resources whose spatial distributions, movements, and exploitation features are stage-specific. For this purpose, it is necessary to account for demographic processes and population structures.

Spatially-explicit demographic models. Many authors have resorted to spatially-explicit versions of models commonly used in fisheries science to demonstrate the impact of MPA, and more generally to investigate the consequences of different allocations of fishing effort over space and/or time.

The equilibrium yield per recruit model proposed by Beverton and Holt (1957, pp. 136-148) was used and modified by several authors (Table 3) to explore the impact of a permanent no-take zone as a function of fishing 
Accepted for publication in Fish and Fisheries

mortality, reserve size and transfer rates between the reserve and the exploited area (Table 4). In such models, implementing a reserve leads to increased yield per recruit and additional spawning biomasses only when fishing mortality is high. Gain in yield is moderate, because of fishing effort reallocation, but spawning biomass substantially increases, even for small reserve sizes. The equilibrium assumption prevents these models from tackling potentially positive effects of reserves (or more generally of fishing effort reallocation) on reproduction and recruitment. They only allow investigation of growth overfishing such as consequences of changes in exploitation patterns and global fishing mortality upon abundance, biomass and catch.

Models including stock-recruitment relationships have been used to study the ability of MPA to address recruitment overfishing via effects on reproduction and recruitment (Table 3). Such models allow dealing with exportation (also termed spillover) of pre-recruited stages from the MPA. When age- or lengthstructured, these models account for increases in mean fecundity per adult due to a higher mean length in the population after reserve establishment (Guénette et al. 2000). Inclusion of a stock-recruitment relationship together with population structure thus leads to a more positive impact of reserves (Attwood and Bennett 1995; Guénette and Pitcher 1999). In this case, yield increases and the population may endure a higher fishing pressure, because the reserve acts as a source of spawners and recruitment.

These spatially-explicit models make it possible to explore the consequences of movements or transport of pre- and post-recruited population stages. Spillover of post-recruited stages may only occur for nonsedentary species, while eggs and larvae may potentially be dispersed in the case of many species with various dispersal schemes (see e.g. Carr and Reed 1992 for examples). The kind of benefits that can be expected from MPA establishment appears largely determined by movement patterns (Attwood and Bennett 1995), but also by movement modelling. For instance, models based on transfer rates (Polacheck 1990; DeMartini 1993) imply that net movement depends on reserve size, reserve shape and population size in each patch. In the case of initial homogeneous abundance distributions and zero net tranfer between patches, these models are close to a random dispersion model (see Beverton and Holt (1957) for a discussion). Several models consider dispersion-like movements and age-independent dispersal coefficients (Table 3). These assumptions may not be apppropriate for populations that undergo oriented ontogenic migrations (see discussion in subsection 5.1). In these models, reserve impact is mostly 
Accepted for publication in Fish and Fisheries

assessed with regard to reserve size and spacing. Consequences of reserve location cannot be addressed unless a large number of patches is considered in the model (see e.g. Maury and Gascuel 1999). As underlined by Guénette and Pitcher (1999), more realistic descriptions of migration and aggregation patterns than simple dispersive movements are needed for improving the analysis of marine reserve impact. This also holds for MPA in the wider sense.

Ontogenic migrations often display seasonal patterns. Other modelling assumptions, and if relevant, an appropriate time scale are needed to describe this kind of spatial dynamics, and to investigate a wider range of policies, including seasonal ones. A number of models were developed in this respect (Table 3). Patch definition relies on the description of population dynamics, i.e. patches correspond to habitats occupied by specific population stages at particular times of the year, e.g. reproduction areas or nurseries. Population movement is simulated so as to mimic observed migration patterns (Walters et al. 1993; Guénette et al. 2000) or to fit existing knowledge (Pelletier and Magal 1996).

Fishing effort allocation is known to be highly dependent upon spatio-temporal patterns of resources, and there are many cases where periodic concentrations of some population stages cause intensive local exploitations (Whitmarsh and Young 1985; Rowley 1994; Vignaux 1996a; Poulard and Léauté 2002, and others). Models depicting spatio-temporal features of resource distribution are needed to explicitly account for such patterns of fishing effort allocation.

Most papers consulted for this review were interested at comparing different management measures, and sometimes they also evaluated the effects of combined management measures (Guénette et al. 2000). Such models make is possible to explore a wider range of MPA designs, varying both size, location and timing of the MPA. For instance, Guénette et al. (2000) considered seasonal closures, and reserves located in migration corridors or on the continental slope, plus combinations of these measures. Dramatically different exploitation rates could be obtained by changing the spatial and seasonal allocation of fishing effort while keeping total effort constant (Pelletier and Magal 1996 ; Verdoit-Jarraya 2003 ; Verdoit-Jarraya et al., unpublished findings ${ }^{2}$ ). More often than not, reserves or seasonal closures appear to be unable on their own to protect stocks from overexploitation (Walters et al. 1993), or even from 
Accepted for publication in Fish and Fisheries

collapse (Guénette et al. 2000). However in Walters et al. (1993), none of the management measures considered (minimal landing size and direct effort limitations) was able to restore the stock, due to the high commercial value of immatures. Pelletier and Magal (1996) and Apostolaki et al. (2002) showed that, unlike reductions in fishing mortality through TACs or overall effort controls, MPA implementation does not necessarily induce short-term losses in yield.

Using these models, MPA appear particularly relevant i) in the case of heavy exploitation; ii) for species with spatial segregation of life stages; and iii) when essential habitats have to be protected e.g. spawning grounds or nurseries (Apostolaki et al. 2002); points ii) and iii) require particularly careful designs to ensure MPA efficiency. MPA design is also critical when it comes to relationships between hydrodynamic conditions and larval dispersion. In the case of Caribbean spiny lobster, Stockhausen et al. (2000) showed that a large number of reserve configurations improved both catch level and larval production. But reserve impact depended in a complex manner on reserve location, reserve size, hydrodynamic scenarios and larval dispersion schemes.

Multispecific and ecosystem approaches. Establishment of MPA or MPA projects are often envisaged in the context of ecosystem-based management (Agardy 1994). However, few ecosystem models have been developed or used to evaluate MPA impact, in comparison to the number of population models quoted above. McClanahan (1995) developed a non spatial ecosystem model to assess indirect consequences of fishing intensity and selectivity. The model was applied to a coral reef ecosystem and adapted to a Mediterranean case by McClanahan and Sala (1997) (Table 5). Boncoeur et al. (2002) considered a predator-prey model with a fish prey and a predator seal species.

The ECOPATH approach (Polovina 1984; Christensen and Pauly 1992) depicts trophic interactions between functional groups, based on biomass flows and mass-balance equations. ECOPATH is not spatially-explicit, but has been used to compare trophic structures in protected and unprotected areas (Arias-Gonzáles 1998, Table 5).

\footnotetext{
${ }^{2}$ Verdoit-Jarraya, M., Pelletier, D. and Gouzé, J.-L. (2004) Modelling the spatial and seasonal dynamics of the whiting population in the Celtic Sea. ICES CM 2004/Y 13.
} 
Accepted for publication in Fish and Fisheries

Derived from ECOPATH (Walters et al. 1997), ECOSIM allows investigating the dynamics of an ecosystem under alternative parameter settings. Walters et al. (1997) proposed it as a tool for building hypotheses about possible effects of management changes such as e.g. changes in fishing pressure and establishment of MPA. Watson et al. (2000) modified ECOSIM by partitioning biomasses into two components corresponding respectively to a protected and an unprotected area, and used it to investigate MPA effects (Table 5). These authors stressed that spatially-explicit models would be more appropriate for evaluating MPA policies. ECOSPACE is a spatially-explicit version of ECOPATH/ECOSIM (Walters et al. 1999). The dynamic model is solved for a two-dimensional grid of cells linked by dispersal and migration processes, which enables one to assess MPA policies while considering trophic linkages. ECOSPACE has been used in several instances to investigate ecosystem effects of MPA, in particular trophic cascading (Table 5). Several studies have shown that these effects could be strongly altered by fishing effort reallocation, and by movement, dispersion scheme and habitat preferences, particularly in the case of mobile species. The ability of ECOSPACE to evaluate MPA is limited by the poor description of movement patterns (ontogenic or seasonal migrations) and of population dynamics (Beattie et al. 2002 ; Martell et al. 2005). Indeed, models based on biomass pools cannot encompass ontogenic migrations that depend on species and stage. As a consequence, relationships between essential fish habitats such as nurseries and spawning areas, and MPA designs cannot be investigated through this kind of models. In addition, spatial patterns due to larval transport and settlement cannot be accounted for (Walters et al. 1999).

Finally, the OSMOSE model of Shin and Cury (2001) was developed to evaluate the dynamics of fish communities. It is individual-based, and depicts trophic interactions between fish schools characterized by their mean size and age. In this model, species can occupy different trophic levels depending on their size. Migrations and seasonal effects are not considered (Table 5). The model was used to explore community-level effects due to reserve implementation (Shin 2001).

\subsection{Modelling exploitation and management policies}


Accepted for publication in Fish and Fisheries

Exploitation is a key component of fisheries dynamics, that conditions both the fishing mortality endured by the resource and the evolution of the fishery. In this section, we present exploitation models according to three aspects : i) spatial allocation of fishing effort; ii) mixed fisheries; and iii) bioeconomic modelling. We then examine policy modelling and fishers' response to management. These four issues obviously interact, but each of them leads to different modelling approaches, which is the focus of this paper.

Dynamics of the spatial allocation of fishing effort. It is not our purpose in this paper to deal comprehensively with the subject of fishing effort allocation, but rather to list models that have been used in fisheries simulation models. Following Hilborn (1985), fishing effort allocation here includes "when to fish, where to fish, and what to fish". Yet, we may distinguish several scales at which the fisherman may decide upon how to allocate fishing effort : i) yearly and longer term scales for deciding whether or not to enter a fishery; ii) seasonal scales for choosing fishing activities that are consistent with the seasonal distribution of resources; iii) before each fishing operation (or trip) for selecting a fishing zone and a fishing activity; and iv) during a fishing operation for fine positioning of gears within the zone. Here, we were mainly concerned with points ii) and iii). Point i) is highly dependent on fleet dynamics and economic strategies, which falls outside the scope of this paper, whereas point iv) does not pertain to management measures. A variety of factors may influence spatial allocation of fishing effort through the perception of expected benefit (see also Salas and Gaertner 2004). The most obvious is knowledge about resource location, for instance measured by past catches or catch rates (Hilborn and Ledbetter 1979; Vignaux, 1996a; Campbell and Hand 1999; Holland and Sutinen 1999; Holland 2000), possibly reweighted by species price (Holland and Sutinen 1999) and harvesting costs, e.g. cost of travelling to fishing grounds. Uncertainty about resource location and communication of information between fishermen are likely to alter fishermen perception of expected benefits (Allen and McGlade 1986). Finally, weather conditions (Campbell and Hand 1999) and fishing habits (Hilborn and Ledbetter 1985; Pelletier and Ferraris 2000; Mahévas and Trenkel 2002; Salthaug and Aanes 2003) also determine to some extent fishing effort allocation. In spite of the number of factors explaining fishing effort allocation, fisheries simulation models generally rely on simplistic descriptions of fishing effort dynamics. Effort may be static, corresponding to a fixed effort distribution between model patches or fishing grounds throughout a given simulation (Sparre and Willmann 
1993 ; Pelletier and Magal 1996). Alternatively, effort may be dynamic, varying at each time step according to some predetermined equation or algorithm. Such models often rely on the assumption that fishermen preferentially allocate fishing effort to areas with highest expected benefit. Hilborn and Walters (1987) sequentially allocated effort between fishing grounds by dedicating a fraction of effort to exploratory fishing, and allocating remaining effort to areas with highest catch rates. Tanaka et al. (1991) used this algorithm for simulating resource dynamics under several management scenarios for a crab fishery. Many models refer to the so-called gravity model of Caddy (1975) which can be written as the general form :

$$
p_{i}=\frac{a_{i}}{\sum_{j} a_{j}}
$$

where $p_{i}$ is the probability of selecting fishing ground $i$, and $a_{i}$ is the attractivity of fishing ground $i$. Attractivity is generally directly linked to expected catch rate or expected revenue, which are often assessed from past CPUE. Because effort appears to be more concentrated in space than expected from the gravity equation, Caddy (1975) reweighted CPUE using historical allocation of fishing effort, implicitly accounting for factors such as traditions, distance to port, interactions between fishers, etc. Several authors have used this gravity equation to describe spatial allocation of effort as a function of expected catch or revenue. For instance, along the same lines as Caddy (1975), Walters et al. (1993) introduced a concentration parameter to augment the attractivity of grounds with high abundances, and they explicitly accounted for distance to port. For high values of the concentration parameter, their model approximates the sequential model of Hilborn and Walters (1987) quoted hereabove. Walters and Bonfil (1999) used a gravity model, which did not consider distance to port, nor traveling costs, but species prices. Seijo et al. (1993) and Seijo and Defeo (1994) accounted for all these factors simultaneously. Allen and McGlade (1986) parameterized in addition information exchanges between fleets and fishers behaviour with respect to risk. ECOSPACE (Walters et al. 1999) also relies on a gravity model for effort reallocation. Walters and Bonfil (1999) demonstrated that the gravity model approximates an Ideal Free Distribution (IFD) of fishing effort (Fretwell and Lucas 1970), which amounts to level off the profitabilities of fishing grounds. Although the gravity model has not been tested from real data, Gillis et al. (1993) showed that the IFD was a good candidate for explaining the spatial allocation of fishing effort 
Accepted for publication in Fish and Fisheries

in the case of the Hecate Strait trawl fishery. Rijnsdorp et al. (2000a and b; 2001) used the IFD assumption to model allocation of fishing effort for the Dutch beam trawl fishery in the North Sea.

Another approach to spatial allocation of fishing effort consists in modelling the probabilities of choosing alternative fishing grounds as a function of explanatory factors. These models are termed multiple choice models or Random Utility Models (RUM) (Eales and Wilen 1986; Wilen et al. 2002; see Hutton et al. 2004 for more details and references) and are fitted to data such as interviews and catch and effort data per trip and per vessel. Results may be used to predict spatial and temporal allocation of fishing effort. Holland and Sutinen (1999) and Hutton et al. (2004) applied multinomial logit choice models to estimate the probabilities of alternative fishers' decisions regarding spatial allocation of effort. Fitted models were then used to simulate effort allocation in fisheries dynamics models (Holland 2000; Hutton et al. 2004). In Holland and Sutinen's (1999) model, the choice of a fishing ground relied on its expected profitability, which depended on the average revenue rate of vessels that fished in that area in the past, and on travel costs. The fact that the vessel already fished there in the past was also taken into account. Hutton et al. (2004) modelled the probability of a vessel selecting a fishing ground as a function of average trip duration, number of trips made to that area and value per unit effort in the past. Spatial allocation of fishing effort has also been modelled from generalized linear or additive models fitted to data aggregated at the fleet level (Vignaux 1996a, Dorn 2001, Punt et al. 2002).

Unlike models based on catch or profit maximization, Fahrig's model (1993) is a two-patch model in which effort in a patch is reallocated to the other when biomass falls below a threshold; that is deemed to reflect fleet mobility. This model differs from previous ones, because effort allocation is seen as resulting from the decision of leaving a fishing ground where catch or CPUE value is not high enough, rather than from an optimal behaviour. This point of view is close to the model of Charnov (1976) used in optimal foraging theory.

Mixed fisheries. As mentioned in the Introduction, description of fishing effort in mixed fisheries is complex due to the diversity of fishing activities characterized by target species, fishing gears and fishing grounds (termed métiers by Biseau and Gondeau (1988)). Métiers reflect the decision made by fishers 
Accepted for publication in Fish and Fisheries

before each fishing operation or fishing trip, and are sometimes called fishing tactics, directed fisheries or fishery management units (see Pelletier and Ferraris (2000) for references). Fishing vessel characteristics are also diverse and vessels may practice several métiers during the year. Fishing activity may be characterized at the scale of the fishing operation, i.e. a few hours or a day, and at the vessel scale, i.e. one or several years (Lewy and Vinther 1994; Hilborn 1985). This complexity and associated technical interactions make it difficult to evaluate fishing mortalities endured by resources. Several models aimed at evaluating technical interactions in mixed fisheries through a realistic description of fishing effort have been developed. The earliest published models were not spatially explicit; they attempted to partition fishing mortalities according to métiers (sometimes called fishery units). Some of these models were diagnostic models for assessing medium-term consequences of static allocations of fishing effort per métier (Murawski 1984; Pikitch 1987 ; Mesnil and Shepherd 1990). Mesnil and Shepherd (1990) proposed an age- and length-structured model to evaluate the consequences changes in mesh size, effort level and allocation between métiers, and minimum commercial size. Yield per recruit computations were carried out by Pikitch (1987) for a set of species exploited by a single fishing activity, and by Murawski (1984) for several fishing activities. These authors evaluated the consequences of mesh size regulations and global effort limitations. Holland and Maguire (2003) analysed catch and revenues arising from alternative effort controls. Murawski and Finn (1986) and Marchal and Horwood (1996) developed optimization models aimed at finding the allocation of fishing effort between métiers or gears that ensures sustainable exploitation. In these models, fishing effort is static and its allocation between métiers or gears is fixed. In contrast, fishing activity is more complex and fishing effort becomes dynamic in Laurec et al. (1991), Laloë and Samba (1991) and Laloë et al. (1998). Fishing vessels were grouped into strategies, i.e. groups of vessels that resorted to the same set of métiers throughout the year. In Laurec et al. (1991)'s model, fishing effort was allocated from year to year between métiers based on a trade-off between rent maximization (selection of the métier with maximum expected benefit) and inertia (tendency to continue using the same métier). The weights of the trade-off were specific to each strategy. In Laloë and Samba (1991)'s model, the proportion of vessels changing métier at a given month was the average of the net expected benefits respectively associated to this métier and to the initial métier, 
Accepted for publication in Fish and Fisheries

weighted by a flexibility coefficient. Expected benefit was calculated as the average of the revenue obtained in the previous month and the revenue obtained the year before in the same month. More recently, Ulrich et al. (2002) presented a bioeconomic model of the North Sea flatfish fishery to compare the biological and economic performances of management by Total Allowable Effort (TAE) versus Total Allowable Catch (TAC). In this model, fishing activity was structured by fleets according to vessel size and gear. Fleets differed through catchability and exploitation costs. Catchability changed over years because of trends in fishing power, in relation with skipper skills (technical efficiciency), vessel characteristics and equipment (represented by the level of investment) and annual time spent fishing (see also Ulrich et al. 1999).

The above models are not spatially-explicit, so that they ignore differences between fishing grounds, and cannot address the question of effort allocation between métiers that exploit distinct areas, depending e.g. on target species distribution and travel costs. In this case, spatially-explicit models are needed to properly explore the dynamics of the fisheries, in particular under MPA management. There are few such models for mixed fisheries.

Allen and McGlade (1986) modelled the dynamics of the groundfish fishery of Nova Scotia to investigate the consequences of fishers' behaviour upon fishery's dynamics, but did not consider management measures. Tanaka et al. (1991) modelled a flatfish trawl fishery in the Japan Sea to explore resource dynamics as a function of spatial allocation of fishing effort. The bioeconomic model BEAM4 (Sparre and Willman 1993) is generic, consisting of a biological and technical submodel to compute the relationship between fishing effort and yield, and an economic submodel to compute various measures of economic performance. Outputs of the bio-technical submodel form the inputs to the economic submodel. Given an initial allocation of fishing effort among fleets, the model computes equilibrium projections. Effort-based management measures may be tested by modifying fleet size, fleet selectivity or the spatial allocation of fishing effort of fleets. More recently, Walters and Bonfil (1999) presented a multispecies spatial stock assessment model for the groundfish fishery of British Columbia to test management measures like global TACs, global effort limitation, and permanent closures of fishing grounds. Differences in fishing activity are described by a set of fishing grounds with distinct species 
Accepted for publication in Fish and Fisheries

compositions. Exploitation is conducted by a single fleet. Holland (2000) modelled the Georges Bank groundfish fishery for investigating the consequences of management by permanent no-take reserves (termed sanctuaries in his paper). Again, fishing activity is determined by selection of a fishing ground corresponding to a particular species, and vessels are assumed identical. Travel time to fishing grounds is accounted for in effort computation. In the case of Australia's South East mixed fishery, Punt et al. (2002) proposed a set of operating models that account for technical interactions and spatial aspects. They were used for evaluating TAC and restrictions on total effort, but not MPA. The TEMAS toolbox (Sparre 2003) contains a spatially-explicit fisheries simulation model intended to assess mixed fisheries and management options including catch quotas and technical measures like closed areas, but no results have yet been published. These two models account for discarding.

To summarize, there exist few spatially-explicit models that include multispecies and multifleet aspects for the purpose of testing the effectiveness of MPA designs. In these models, fishing activities are defined by fishing grounds. The explored MPA designs are mostly permanent no-take zones.

Bioeconomic modelling. By bioeconomic modelling, we mean fisheries models that incorporate economic parameters or variables, either as forcing variables or endogeneous variables (i.e. variables with their own dynamics in the model). Several models quoted in the subsection on spatial allocation of fishing effort include a behavioural component of effort allocation in response to spatio-temporal variations in economic variables. At this stage, we concentrate on models that evaluate economic consequences of MPA at the scale of the fishery, and we only describe the economic component of bioeconomic models since biological components were already dealt with in subsection 2.1.

BEAM4 (Sparre and Willman 1993) is the first bioeconomic model for evaluating consequences of alternative spatio-temporal allocations of fishing effort (even if it was not presented in this perspective). In this static model, the economic performance of the fishery is calculated from fixed costs and fixed prices.

Sanchirico and Wilen (1999, 2001a and b) proposed dynamic models where the rent function depends on the management of the fishery at stake. Recall that, in an open-access fishery, rent is dissipated at 
Accepted for publication in Fish and Fisheries

equilibrium (Gordon 1954), so that net rent in each patch tends to zero. Sanchirico and Wilen (2001b)'s model includes global costs (opportunity cost tied to vessel capital and ex-vessel price) and patch-specific costs per unit effort (sometimes termed proportional costs). The Schaefer production function is also specific to each patch. In this model, the equilibrium is only affected by biological parameters, while economic response rates influence the convergence rate to the equilibrium. In particular, these authors look for conditions that guarantee a double payoff, i.e. an increase in both yield and biomass (Tables 2 and 6). The model was adapted by Sanchirico and Wilen (2001a) to depict a limited-entry fishery managed through vessel licenses. The rent then comprises in addition the opportunity cost tied to license price. The impact of reserve creation is studied for a three-patch system with different biological connectivities between patches (closed populations, adjacent populations linked, all populations linked) (Table 2).

Boncoeur et al. (2002) considered not only fisheries objectives, but the ecotouristic value of a seal population that is a predator of an exploited fish population (Table 6). Ecotouristic rent is modelled through a Cobb-Douglas production function. In the ECOSEED model developed from ECOSPACE by Beattie et al. (2002), each fishing ground (i.e. each grid cell) is assigned an economic value that encompasses revenues per fleet and per biomass pool and existence values of species pools, as well as fixed costs and operating costs. ECOSEED aims at finding the MPA design which maximizes economic rent and/or existence value under several policies. Existence value refers to conservation objectives. These authors considered a no-take zone and a trawl-exclusion MPA in the North Sea (Tables 5 and 6). Sumaila (2002) searched for optimal reserve size in a cod-like fishery with a coastal fleet and a trawler fleet, considering separate or joint management.

To the exception of Beattie et al. (2002) who considered a trawl-exclusion scenario, published bioeconomic models only addressed no-take zones, and not MPAs in the form of spatial restrictions of targetted fishing activities.

Policy modelling and fishers' response to management. In the papers listed above, the establishment of an MPA was modelled as a fraction of the region closed or a constraint on effort allocation. Most papers focused on 
Accepted for publication in Fish and Fisheries

no-take zones, and MPA were rarely compared with other management measures (Tables 2, 4, 5 and 6). Along

the same line of thought, few models were able to investigate the performance of combined management policies (Tables 4 and 6). However, such investigations are necessary because the ability of MPA to ensure resource conservation and reduce overexploitation is much improved when additional management measures are simultaneously implemented.

As noted by many authors, MPA impact will largely depends upon the way fishing effort is reallocated after implementation. Many of the models quoted above assume more or less implicitly that effort uniformly redistributes over the remaining fisheries area. In bioeconomic models, fisher's response is generally made endogeneous through optimization behaviours that are mostly theoretical models. Beattie et al. (2002) and Sumaila (2002) consider responses based on game theory: fleets may either cooperate, i.e. seek to maximize joint benefit to the fishery, or not, i.e. seek to maximize their own benefit.

Many models are unsuitable to investigate fisher's response either because authors assume a static distribution of effort and compare alternative fishing effort allocation schemes, or because fishing effort dynamics is not directly affected by policies. Another reason for the lack of account for fisher's response pertains to the lack of empirical studies aimed at analyzing this response, e.g. from interviews (but see Rijnsdorp et al. 2001). A conspicuous example of fishers response to policy options is provided by discarding or highgrading behaviours that may result from TAC regulations. For instance, Ulrich et al. (2002) considered in their model that fishers caught species with the largest TAC, and discarded the others.

\section{A generic simulation tool for policy evaluation}

Several points raised in the review are addressed in ISIS-Fish (Integration of Spatial Information and Simulation of FISHeries management), a simulation tool based on a spatially-explicit model of fisheries 
Accepted for publication in Fish and Fisheries

dynamics, and aimed at evaluating the impact of a variety of policies on the dynamics of a mixed fishery.

As it is generic, ISIS-Fish may be applied to any fishery that can be described by the modelling framework.

A preliminary version of the conceptual model was presented in Pelletier et al. (2001). Model implementation and the description of the version 1.0 of the software may be found in Mahévas and Pelletier (2004). In the present paper, we focus on fisheries modelling and evaluation of management measures. In particular, we present modelling choices made in ISIS-Fish, and discuss them in the light of the previous review. The presentation refers to version 1.5 that contains several changes in the model compared to version 1.0. The software may be downloaded from http://isis-fish.labs.libre-entreprise.org/. The most complex version of the model is presented; however the model may be applied to simpler fisheries, e.g. with only one species, a single fishing activity and non-spatialised dynamics.

The model consists of three submodels : a population model, an exploitation model, and a management model. The population and exploitation models interact through the relationship between fishing effort and fishing mortality. The exploitation model depends on the management model, because fishing effort is made dependent on management constraints and fishers' response to these constraints.

\subsection{Spatial and seasonal scales in the model}

The dynamics of the fishery is represented over a grid encompassing the region where the fishery takes place. Grid resolution is chosen by the user according to the questions addressed and according to the detail of knowledge available about the fishery. Population zones, fishing zones (called métier zones, see subsection 3.3) and management zones are defined independently and are specific to each population and each fishing activity (Figure 1). A monthly time scale makes it possible to describe seasonal patterns. Seasonal patterns and biological processes are assumed to remain unchanged across years. For each population (resp. métier), the spatial distribution of abundance (resp. fishing effort) is assumed to be fixed during a population (resp. métier) season. It is uniform within corresponding population or métier zone. 
Accepted for publication in Fish and Fisheries

For each population and each fishing activity, the relationship between fishing effort and fishing mortality is directly linked to the extent and duration of the spatial overlap between the fishing zone and the population zone (see discussion). Similarly, the impact of a policy on a given fishing activity depends on the overlap between the management zone and the fishing zone. The dynamics of populations and fishing activities are thus superimposed. The number of entities (population, fishing activities) that may be specified in a fishery is therefore only limited by computational considerations.

\subsection{Population dynamics}

Given a hierarchical conceptual model of the fishery (Pelletier et al. 2001), several populations may be defined for a given species. A species is characterized by its scientific name, and by the fact that the population is either stage-, length- or age-structured. Predator-prey relationships between species are not considered in the model.

The model aims at depicting seasonal and spatial variations in population abundance, which are tied to large-scale ontogenic migrations such as migrations of spawners for reproduction, and migrations linked to habitat preferences such as nurseries or feeding areas. Population seasons are thus defined according to the timing of biological processes such as migrations, growth, reproduction and recruitment. Subdivided population models based on patches and migration between patches were deemed appropriate for describing this kind of dynamics (Lebreton 1996).

For a given population, class- and zone-specific abundances at the beginning of time step $t$ are denoted :

$$
{ }^{\mathrm{t}} \mathrm{N}(t)=\left(N\left(t, z_{1}\right), \ldots, N\left(t, z_{j}\right), \ldots N\left(t, z_{n}\right)\right)
$$

where ${ }^{t} \mathrm{~N}(t)$ is the transpose of $\mathrm{N}(t), N(t, z)$ is the row vector $(N(t, c, z), c=1, \ldots, N b C l a s s)$, and $c, z$, NbClass and $n$ respectively denote a population class, a population zone, the number of classes and the number of zones of the population.

Migrations, spawning, recruitment, and change of class are assumed to occur instantaneously at the beginning of the time step following the chronology in Figure 2. However, all processes do not 
Accepted for publication in Fish and Fisheries

necessarily occur at all time steps. Corresponding equations are given in Appendix 1. Assumptions about migrations are discussed in subsection 5.1.

Unlike other demographic processes, natural and fishing mortalities affect population abundance throughout each time step (Figure 2). Survival rates follow the classical exponential decay model widely used in fisheries models, so that the survival rate of class $c$ at time $t$ in population zone $z$ is :

$$
\operatorname{sr}(c, z, t)=\exp (-(F(c, z, t)+M(c)))
$$

where $F(c, z, t)$ and $M(c)$ respectively denote the instantaneous fishing mortality rate of class $c$ in zone $z$ at time $t$, and the instantaneous natural mortality rate of class $c$. In this formulation, mortalities are both expressed in month ${ }^{-1}$. Natural mortality is assumed to be identical in all zones and all months. Fishing mortality is computed from fishing effort as described in subsection 3.4. Survival rates are arranged into a diagonal matrix SR(t).

From the chronology of processes (Fig. 2), the evolution of population abundance between $t$ and $t+1$ is written as :

$$
\mathbf{N}(\mathbf{t}+\mathbf{1})=\mathbf{S R}(\mathbf{t})\left(\mathbf{R}(\mathbf{t})+\mathbf{D}_{\text {season }}^{\mathrm{mig}} \mathbf{C C}_{\text {season }} \mathbf{N}(\mathbf{t})+\mathbf{N}_{\text {season }}^{\text {immig }}\right)
$$

where $\mathbf{R}(\mathbf{t})$ is the recruitment vector, $\mathbf{D}_{\text {season }}^{\text {mig }}$ is the migration matrix, $\mathbf{N}_{\text {season }}^{\text {immig }}$ is the immigration vector, and $\mathbf{C C}_{\text {season }}$ is the matrix depicting change of class due to aging in the case of an age-structured model, and to individual growth in the case of a stage-structured model (see Appendix 1 for details on matrix construction and on change of class). Equation (3) is simplified if not all demographic processes occur at time $t$.

\subsection{Exploitation}

In mixed fisheries, vessels generally differ by their size and as a consequence by their travelling capabilities. This was modelled through so-called fleets that comprise vessels making trips of the same duration (Table 8). Trip duration may be a day, a week, a fortnight or a month, and it determines the 
Accepted for publication in Fish and Fisheries

maximum time spent fishing and travelling to fishing grounds each month. Considering several fleets is particularly interesting in coastal fisheries, where fishers' response to management measure may depend on their geographical activity range. For instance, it may happen that large vessels make short fishing trips in coastal areas, whereas they usually exploit more remote grounds. Excluding these vessels from coastal grounds is a potentially relevant policy option.

Fishing activity at the trip scale is defined through métiers, unambiguously described by the combination of one or several target species, one fishing gear, and one fishing ground (see subsection 2.2. under "Mixed fisheries") (Table 8). Fishing follows seasonal variations in population abundance, and métiers are generally practised during specific periods of the year. In a mixed fishery, the variety of target species results in several groups of vessels resorting to the same sequence of métiers throughout the year. From now on, we use the term "fishing unit" (i.e. a vessel plus a crew) rather than "vessel" to emphasize that the fishing strategy is tied to skipper choice, not only to vessel type. In ISIS-Fish, these groups of fishing units were termed strategies (Table 8). They may comprise fishing units from several fleets.

Fishing effort per métier is calculated at the month scale for a given métier, as a function of métier and gear-related parameters (Table 8). Consistently with previous definitions, fishing effort at month $t$ is calculated in several steps (see parameter notations in Table 8).

For each métier, an average travel time $\bar{T}_{\text {travel }}(m, t)$ is computed over métier zones at $t$, differences in speed between fleets being ignored in the model. Under these assumptions, fishing time per fishing unit of fleet $f$ practising métier $m$ is :

$$
\operatorname{Time}_{\text {fishing }}^{F U}(m, f, t)=\text { MaxTime }_{\text {month }}^{\text {sea }}(f)-\operatorname{NbTrips}_{\text {month }}(f) \bar{T}_{\text {travel }}(m, t)
$$

Fishing time is converted to standardized fishing effort, accounting for both the gear used by the métier and the number of fishing operations per day which is métier-specific. Standardised fishing effort per fishing unit per fleet and per métier gives :

$$
E^{F U}(m, f, t)=\rho_{\text {std }}(g) N b O p_{\text {day }}(m) \operatorname{Time}_{\text {fishing }}^{F U}(m, f, t)
$$


Accepted for publication in Fish and Fisheries

Fishing effort per fishing unit then serves to compute total fishing effort per strategy and per fleet, accounting for both the number of fishing units and the allocation of effort between métiers:

$$
E(m, s t r, f, t)=N b F U(s t r, f) \operatorname{PropStr}(s t r, m, t) E^{F U}(m, f, t)
$$

Total standardized fishing effort of métier $m$ at time $t$ is obtained by summing over strategies and fleets in equ. (6) :

$$
E(m, t)=\sum_{s t r} \sum_{f} E(m, s t r, f, t)
$$

In a last step, fishing effort of métier $m$ is allocated between métier zones of $m$ at time $t$, assuming a uniform distribution of effort over the cells of each métier zone (see discussion). Fishing effort in métier zone $z$ is then :

$$
E(m, z, t)=\frac{E(m, t)}{\sum_{z \in Z} N b \operatorname{Cells}(z)} \operatorname{NbCells}(z)
$$

where $Z$ is the set of métier zones of $m$ at $t$, and $N b C e l l s(z)$ is the number of cells of the métier zone $z$.

\subsection{Relationship between fishing effort and fishing mortality}

Population and exploitation models are coupled via the relationship between fishing effort and fishing mortality, the latter serves to calculate population survival rates.

Each month, fishing effort of métier $m$ is allocated to population zones in proportion to the intersection between the population zone and the métier zone, assuming a uniform distribution of effort within the métier zone. If the métier has several métier zones at $t$, fishing effort per population zone is obtained by adding efforts from all métier zones that intersect the population zone. Hence,

$$
E(m, z p, t)=\sum_{z m \in Z} \frac{E(m, t)}{\sum_{z m \in Z} N b \operatorname{Cells}(z m)} N b \operatorname{Cells}(z p \cap z m),
$$

where $N b C e l l s(z)$ is the number of cells of zone $z$. 
Fishing mortality is then obtained considering gear selectivity, population catchability and métier target factor :

$$
F(c, z, m, t)=\sigma_{p o p}(m, t) \operatorname{Sel}_{p o p}(\bar{l}(c), g) q(c, z, t) E(m, z, t)
$$

where $q(c, z, t)$ is the catchability coefficient of class $c$ in zone $z$ at $t$. This equation relies on the assumption that fish instantaneously redistribute within their population zone during month $t$.

The target factor $\sigma_{p o p}(m, t)$ is necessary to distinguish the impacts of a métier on its target species and on bycatch species. Also, two métiers fishing in the same zone at $t$ will induce distinct fishing mortalities on a population, depending on the target factor. These differences are tied to species attractivity, and they include the savoir-faire of the fishers resulting in fine tuning of gears, e.g. rigging, precise positioning of gears, which are not captured by gear parameters, nor by the spatial resolution of the model. For a given métier and population, $\sigma_{\text {pop }}(m, t)$ depends upon season because of métier seasonality, but it is assumed constant over population stages for simplication. Selectivity of gear $g$, denoted $S_{\text {pop }}(\bar{l}(c), g)$, is a function of the average fish length in population class $c$. It also depends on the value of the gear parameter.

Note that in this model catchability is the probability that a fish present in the exploitation zone be caught by a standard unit of effort made from a non selective gear, consistently with Seber (1989)'s definition, and sometimes termed fish availability or fish accessibility. This parameterization enables us to distinguish gear-dependent selectivity effects from gear-independent catchability. Catchability may change during the year due to particular behaviour, e.g. the burrowing of egg-bearing female Norway lobster (Nephrops norvegicus, L. 1758) (De Figueiredo and Thomas 1967), or due to seasonal concentrations of particular population stages, like spawning (Hall et al. 1988; Rowley 1994) or wintering areas (Whitmarsh and Young 1985; Anonymous 1997, 1999). These preferential habitats are in general small compared to the distribution area of the population, resulting in concentration effects and increased 
Accepted for publication in Fish and Fisheries

fishing mortalities. The catchability model in ISIS-Fish is such that changes in catchability due to these concentration effects are consistent between stages, zones and seasons (see Appendix 2).

Finally, fishing mortality is summed over métiers to compute the survival rates of equation (2) at time $t$ :

$$
F(c, z, t)=\sum_{m} F(c, z, m, t)
$$

Given the chronology of processes in the model, fishing mortality applies to $\mathrm{N}(t+\varepsilon)$ and not to $\mathrm{N}(t)$

(Fig. 2), and the number of fish caught in zone $z$ between $t$ and $t+1$ is computed using the classical catch equation :

$$
C(c, z, t)=\frac{F(c, z, t)}{F(c, z, t)+M(c)}(N(c, z, t+\varepsilon)-N(c, z, t+1)), c=1, \cdots \text { NbClass, }
$$

where :

$$
N(c, z, t+1)=N(c, z, t+\varepsilon) \exp (-(F(c, z, t)+M(c))), \quad c=1, \cdots N b C l a s s
$$

Catches per métier are calculated as :

$$
C(c, z, m, t)=\frac{F(c, z, m, t)}{F(c, z, t)} C(c, z, t), c=1, \cdots \text { NbClass }
$$

\subsection{Policy modelling and fishers' response to management measures}

The primary goal of ISIS-Fish is to evaluate and compare the consequences of policies on the dynamics of a mixed fishery. Particular attention was paid to policy parameterization, so that a wide range of policies may be considered, from conventional options like catch quotas (Total Allowable Catch (TAC)), direct effort control (licences, trip limitations) and gear restrictions, to MPA. As mentioned in the introduction, MPA is here taken in the wider sense of any policy that restricts exploitation in space and 
Accepted for publication in Fish and Fisheries

possibly in time. Because our model is spatially explicit with a monthly time step, the policies considered may apply either during some months or throughout the year, and may either apply on the whole fishery region or within a particular zone. In addition, fishing was parameterized to accommodate for policies that target particular gears, métiers, fleets or strategies, and through several effort parameters (see Table 8). Thus, a variety of MPA designs and other policies may be explored from ISIS-Fish.

Each policy is defined by a zone, a season (starting and ending months), and the years of application. Additional parameters may be specified depending on the policy, e.g. populations subject to TAC and TAC level for each of them, or métiers targetted by the policy, etc. For each policy, the model describes the conditions under which the policy becomes effective, e.g. starting month. For instance, in the case of a TAC, the condition is that cumulated landings since the beginning of the year exceed the TAC value for the species. Implementation of policy results in constraints on exploitation, that lead fishing units to modify fishing effort in some respect. These changes are termed « fishers' response to management measure » in the following. As mentioned earlier, accounting for these responses permits a more realistic assessment of the impact of a policy on both resources and fishing activities. Compliance to management measure may also be accounted for in fisher's response.

When a management measure becomes effective, it impacts any métier whose fishing zone intersects the management zone. Fishers' response depends on their fishing habits reflected by the strategy and the métier practised during the management season. Given the parameterization of effort (Table 8), the response may i) affect a métier parameter, for instance the value of the controllable parameter of the gear, the target factors, or the métier zone ; ii) induce changes in métiers by reallocating effort to other métiers, either in the same strategy or in other strategies; or iii) change the number of fishing units per fleet and/or strategy, for instance in the case of a license system. For instance, when a TAC is reached, fishers' response must describe how the effort of every métier catching the species is reallocated to other métiers.

In practice, policies and fishers' response are coded through an interpreted script language that does not require recompiling the software after changes (Mahévas and Pelletier 2004). For each policy, the script describes the conditions under which the policy is applied and the way effort parameters are affected by policy implementation and associated fishers' response (see Pelletier et al. (2001) for examples of policies). 
Accepted for publication in Fish and Fisheries

The model may consider any policy which can be structured as defined above. Several measures can be combined into a management scenario using a script that contains the conditions of application and the consequences of the measures to be tested. Similarly, any fishers' response that can be written as a decision rule depending on model parameters or variables may be implemented. Note also that policyindependent fishers' behaviours may also be modelled by specifying a policy that is not constraining exploitation.

\section{An illustrative example}

\subsection{Fishery parameterization}

A simple example of mixed fishery was considered to illustrate the suitability of ISIS-Fish for policy evaluation.

The fishery takes place in a region of 20 cells with a spatial resolution of $1^{\circ}$ in latitude and longitude (Figure 3, top left) and exploits two age-structured populations (Table 9) whose seasonal and spatial dynamics mimic demersal North-East Atlantic fish populations that reproduce in the first quarter and exhibit early maturity (Figure 3). Reproduction is a linear function of spawner numbers and fecundity rates; it is distributed over 3 months, from January to March for population 1 and from February to April for population 2. Recruitment starts in May for population 1 and in September for population 2. Distribution of reproduction and recruitment over their respective seasons exhibit a peak (Table 9).

Exploitation is carried out by two métiers. Métier 1 target population $1(\sigma=4)$ and incidentally catches juveniles from population $2(\sigma=1)$ from May to December. It uses gear 1 with selectivities-at-age of $(0,1,1)$ for population 1 and $(0.5,1,1,1)$ for population 2 . Gear 1 is the standard gear $\left(\rho_{\text {std }}=1\right)$. Because it targets population 1, métier 1 fishes exclusively in métier zone zm1 throughout the year, thus overlapping the area of distribution of the matures of population $1(\mathrm{zp} 2)$ and intersecting zp3 where immatures of population 1 are present part of the year (Fig. 3). Métier 2 targets population $2(\sigma=4)$. It uses gear 2, which is $50 \%$ more efficient than gear $1\left(\rho_{\text {std }}=1.5\right)$, but also more selective with selectivities-at-age of $(0,0,1)$ for population 1 and $(0,0,1$, 
Accepted for publication in Fish and Fisheries

1) for population 2. The distribution of effort for métier 2 follows the distribution of the matures of population 2 ,

i.e. zm2 from May to January, and zm3 from February to April. Métier 2 does not generate incidental catch of population 1 (although $\sigma=1$ ) because it uses a selective gear. Note that in this simplified example target factors are independent of seasons. Métiers 1 and 2 are defined so that simulations illustrate the issue of incidental catch and selectivity for mixed fisheries. In the absence of management policy, the above allocation of fishing effort remains unchanged from year to year for both métiers.

There are two fleets making trips of duration 5 days $\left(f_{1}\right)$ and 14 days $\left(f_{2}\right)$, respectively. Corresponding fishing units are distributed between two strategies : strategy 1 uses only métier 1 throughout the year and comprises 50 fishing units from fleet $f_{1}$ and 20 fishing units from fleet $f_{2}$, while strategy 2 comprises 10 fishing units from fleet $f_{1}$ and 30 fishing units from fleet $f_{2}$. From January to April, half of the fishing units of strategy 2 practise métier 1 , the other ones using métier 2, and from May to December, all of them practise métier 2.

Given these population and exploitation parameters, both population are overexploited, i.e. biomass and catch exhibit declining trends over time in the absence of management (Figure 4). In order to restore them, we investigated management scenarios involving MPA and TAC policies (Table 10). First, we considered two MPA scenarios aimed at protecting spawner concentrations of population 1 by closing 3 cells zg3 (Fig. 3, bottom), i) from January to April , and ii) permanently (Table 10). The sensitivity of fisheries dynamics to MPA size was investigated through additional scenarios involving the seasonal closure of zg3, namely: i) closing only two cells of zg3; ii) closing four cells of zg3; and iii) closing five cells of zg3 (Fig. 3, bottom). We then considered a seasonal closure of reproduction zone for population 2 (zg2), and a seasonal closure of zone zg1 where incidental catch of population 2 juveniles take place during recruitment season. A TAC policy aimed at decreasing the fishing pressure endured by population 2 was also tested. Preliminary simulations showed that a TAC level of $210 \mathrm{kt}$ was needed to restore population 2. Note that by definition, discards are not taken into account in the computation of TAC consumption. The last scenario considered was a combination of TAC (210 kt for population 2) and MPA (Table 10).

Fisher's response to TAC implementation is as follows : as soon the TAC of a species is reached, the métiers for which the species is an important target reallocate effort to other métiers according to priorities depending on gear and strategy. Other métiers simply discard species catch altogether. In the case of an MPA, the métiers 
Accepted for publication in Fish and Fisheries

directly affected by the MPA are those whose métier zone intersects partially or totally with the management zone. When the intersection is partial, effort is reallocated to the rest of the métier zone; when the métier zone is enclosed in the management zone, fishers remain at port. This latter choice was made for simplification; alternatively, fishers may have switched to the other métier. These decision rules led to the effort reallocations indicated in Table 10.

\subsection{Results}

As mentioned in subsection 4.1, the current parameterization of the model was such that both populations were overexploited when no policy is regulating exploitation (Fig. 4). Seasonal variations of population and exploitation dynamics were illustrated by biomass and catch trajectories. A seasonal MPA located in zg3 (Fig. 3, Table 10) was efficient at reversing overexploitation for population 1, but not for population

2 (Fig. 4). In the case of population 1, note that seasonal patterns in biomass and catch were modified by implementation of an MPA; in particular, catch was more evenly distributed throughout the year. This MPA design barely affected population 2 .

Scenarios were compared for biomass and catch ratios computed as follows : population biomass in the last time step of the final year simulation (December, year 10) was divided by population biomass in December of the second year. For catch, cumulated catch in year 10 was divided by cumulated catch in year 2. We used values in year 2 rather than in year 1, since they were less sensitive to initial conditions. These two ratios, respectively denoted $\mathrm{F} / \mathrm{I}$ biomass ratio and $\mathrm{F} / \mathrm{I}$ catch ratio, illustrate the restoration of population and subsequent catches throughout the simulation. To facilitate comparison across scenarios, we also computed ratios relative to the final year with and without policy. For a given scenario and population, we thus divided i) population biomass in December of year 10 under that scenario by population biomass in December of year 10 in the absence of policy, denoted w/wo biomass ratio; and ii) cumulated catch in year 10 under that scenario by cumulated catch in the absence of policy, denoted w/wo catch ratio. 
Accepted for publication in Fish and Fisheries

We first investigated the influence of zg3 size upon biomass and catch of population 1 (Figure 5). An MPA smaller than 4 cells appeared inefficient at restoring the biomass of population 1 (Fig. 5a). Furthermore, final catch was larger than initial catch only for MPA sizes larger than 4 cells (Fig. 5b). The seasonal closure of zg3 induced a decline in catch in the first year (Fig. 4). In contrast, biomass increased as soon as the MPA was implemented. Ratios of final biomass (or catch) under the MPA to final biomass (or catch) without fishing regulation (Figs 5c-d), showed that, whatever the size of $\mathrm{zg} 3$, the status of population 1 would have been worse in the absence of policy, and that final catch was in any case larger with a seasonal closure of $\mathrm{zg} 3$ than without regulation, e.g. 9\% larger in the case of a small-sized MPA and $47 \%$ larger in the case of a medium-sized MPA (3 cells). Note that a 4 cells closure amounts to closing $57 \%$ of the métier zone for métier 1 during 4 months. In the same series of simulations, we considered a permanent closure of zg3 (3 cells) (point in Figs. 5a-d). Results showed that extending the January-April closure to the entire year did not provide any additional benefit neither to population 1 nor to catch, although individuals of age 2 are located in the area closed from May to December (Fig. 3).

We then compared a TAC policy and several MPA designs (Table 10), including the MPA-zg3 mentioned above. Biomass and catch ratio based on initial and final values showed that few policies were able to restore populations (Fig. 6a) given initial population sizes. The TAC on population 2 improved catch and biomass ratio for this population (Fig. 6a), but was moderately harmful for population 1 due to effort reallocation once the TAC was reached (Table 10). We further explored other TAC values to better appraise their consequences on catch and biomass (Figures 7a-d). Only TAC values lower than $240 \mathrm{kt}$ would be able to increase the biomass of population 2 with respect to the initial situation (Fig. 7a-b). Note that several values of TAC may lead to similar biomass and catch ratios because the TAC is reached during the same month (Fig. 7), a result that cannot be anticipated from stock assessment projection models based on a yearly time step, and that can be explained by the monthly time step of our model. For the range of TAC values explored, catches would increase from ca. $25 \%$ with respect to the first year. Any of the TAC values considered improves biomass and catch compared to a scenario without policy (Fig. 7c-d). However, under a TAC policy, a fraction of the catch was not landed but discarded. Here, population 2 was discarded by métier 1 that did not target this population. When the TAC value was 210 
Accepted for publication in Fish and Fisheries

$\mathrm{kt}$, discards increased at the same pace as landings throughout the simulation (Figure 8). They formed a large fraction of the catch, which is undesirable.

The MPA aimed at protecting population 2 during reproduction (MPA-ZG2) was ineffective (same ratios as without policy, Fig. 6b). The MPA aimed at protecting population 1 (MPA-ZG3 with 4cells) was effective for population 1 (Figs. 6a-b, see also Fig. 5), but moderately harmful to population 2 due to effort reallocation (Table 10, Fig. 6b). Among the scenarios considered, this one was the most beneficial to population 1, biomass (resp. catch) being multiplied by 3 (resp. 2) at the end of the simulation, compared a scenario with no policy (Fig. 6b). All these measures aimed at a single population had negative impacts on the other one. We thus combined a TAC for population 2 and the MPA-ZG3 with 4cells (aimed at restoring population 1). This scenario improves biomasses and catches for both populations (Fig. 6a), although MPA benefits for population 1 were mitigated by effort reallocation linked with TAC implementation. In contrast, this combined scenario increased population 2 biomass and catch more than the TAC on its own, whereas the MPA alone does not improve the status of population 2. Hence, combined measures may be more efficient than individual ones, and a population may benefit from an additional measure, even if it is not targetted by the measure. Therefore, it is important that models are able to consider scenarios involving several measures, and to evaluate their consequences on several populations and métiers.

Finally, as expected, the small MPA aimed at reducing technical interactions (MPA-ZG1) moderately increased biomass and catch for population 2, whereas population 1 was barely affected. These results illustrated the fact that a small and temporary MPA may entail non negligible benefits to a fishery if properly sited with respect to both population and exploitation features. Population 2 being initially overexploited, implementation of MPA-ZG1 results in catch increase because the overall exploitation pattern of the population is improved.

These results showed that policy consequences may be difficult to anticipate, even in a simple case. Some of our results may be due to the zoning and timing chosen for populations and métiers, and they should not be taken as evidence for the relative performance of TAC versus MPA in general. We believe policy 
Accepted for publication in Fish and Fisheries

performances are highly dependent on the fishery of interest. In addition, we did not carry out a full sensitivity analysis for parameters and initial population sizes. The example was only for illustrating the use of ISIS-Fish for policy screening. Other studies including sensitivity analyses and comprehensive simulation designs, are being undertaken to investigate these issues in the case of real fisheries (e.g. Drouineau et al. (unpublished findings $\left.{ }^{3}\right)$ ).

\section{Discussion}

In this section, we discuss the results of the review in the light of section 4, first for ecological models, i.e. population and trophic models, and then for exploitation and management models. In the last subsection, we propose desirable features for policy-screening tools.

\subsection{Which ecological models for MPA evaluation ?}

Many different models have been proposed for exploring the impact of MPAs on the dynamics of exploited populations. Simple models are mainly heuristic and suited to address general questions, whereas more sophisticated models are more useful for issues of MPA design and quantitative evaluation of MPA impact. This dichotomy was also pointed out by Gerber et al. (2003) under the terms of strategic versus tactical models (following Levins 1966). Despite this typology, both kinds of models are often used to make recommendations about the MPA designs required for achieving conservation and sustainable exploitation goals.

Our review points out the discrepancies and sometimes the contradictions between results obtained from different models. Although model objectives may not be the same, it is necessary to put these discrepancies in perspective. For this purpose, the different model types were considered in light of their ability to address and assess the effects that can be expected from MPA establishment. Ecological and fisheries-related effects were listed from review papers about MPA (see Pelletier et al. (2005) for a list of effects). Based on our literature review, we rated each model type with respect to its ability to address a given effect (Table 7). Although subjective, this rating illustrates the need to resort to spatially-explicit models to evaluate MPA-related effects. It also highlights that there is presently no modelling tool to investigate the full range of effects expected from 
Accepted for publication in Fish and Fisheries

MPA. This is not surprising since effects pertain to different processes involving different scales in time and space.

In terms of resource conservation goals, the papers reviewed generally conclude that MPA may be useful to maintain or restore populations. Most of the papers listed only consider no-take reserves. Recommendations about the appropriate MPA design required to achieve conservation are diverse. In non spatial models, unrealistically large reserves are found to be necessary, particularly in the absence of other policies (Table 2). Note however, that in overexploited situations, the fishing effort reduction required to restore resources may be as unrealistic as the MPA size needed to meet the same objective (Pelletier and Magal 1996). When it comes to spatially-explicit models, reserve location is an additional parameter to be considered for MPA design, and an appropriate location with respect to population and exploitation dynamics has been shown to be as important as reserve size (Table 4, Stockhausen et al. 2000; Meester et al. 2001; Morgan and Botsford 2001; Apostolaki et al. 2002). Die and Watson (1992) and Crowder et al. (2000) predict that reserves may even have negative effects if badly located or designed. In addition, a large but poorly located MPA may provide a false sense of security (Stockhausen et al. 2000). In the case of seasonal patterns, the adequate timing of the closure or management measure is an additional important factor for MPA efficiency (Pelletier and Magal 1996; Guénette et al. 2000). Population movements and mobility appear critical for MPA efficiency; the way movements are modeled determines the kind of movements investigated. Many models assume dispersal rates corresponding to nonoriented diffusion-like movements. Such models are particularly appropriate for pelagic species. Under this assumption, the degree of mobility might mitigate positive effects within and outside the reserve (Table 4). But, even for mobile species, a reserve is a way to increase population resilience, particularly if the reserve encompasses a reproduction zone. Other models depict movements occurring at particular times and quantified by migration rates (or transfer rates, Table 4). These are relevant for depicting movements that are predictable, oriented, and possibly restricted in range. These models are not appropriate to study MPA efficiency as a function of fish mobility because fish mobility is limited in range and timing. Conversely, they give more insight into issues of MPA location, size and timing. They do not account for dispersion effects that tend to smooth spatial distributions of fish; in contrast, they are needed to depict spatial concentrations of fish due e.g. to ontogenic migrations and stage-specific habitat preferences, which are inherent to many fish populations. These 
Accepted for publication in Fish and Fisheries

processes induce spatial segregations of stages and seasonal concentrations of abundances resulting in increased vulnerability to fishing. In that case, accounting for seasonal patterns is important, but rarely taken into account in the models reviewed, so that designs linked with timing of closures may not be investigated. The ISIS-Fish population model was indeed designed to address these issues. Like many spatially-explicit models quoted in the review, it is a subdivided population model (Lebreton 1996), i.e. an age or stage-structured model where the population is distributed in a limited number of zones. Its main features are the exponential decay model, growth and reproduction functions, and discrete migrations based on transfer rates (see subsection 3.2). There are still some limitations in the population model. Hence, in the case of sedentary species, it is necessary to define a population zone for each cell comprised in the area of distribution, to limit dispersion-like effects linked to the assumption of homogeneity within a population zone. Also, the assumption of instantaneous redistribution of abundance (resp. effort) within each population (resp. effort) zone facilitates calculating fishing mortality, but results in underestimating the protection provided by an MPA that does not comprise the entire population zone. Models assuming instantaneous discrete migrations are not fully appropriate for depicting gradual ontogenic movements of fish, such as migration toward deeper waters as fish get older; though they can used for this purpose in first approximation. A model describing at the same time small-scale dispersion and large-scale migrations would be more satisfying in this respect (see e.g. Holland 2000).

There are few examples of subdivided population models that explicitly depict spatial and seasonal aspects linked to ontogenic processes (Walters et al. 1993; Pelletier et al. 1996; Holland 2000; ISIS-Fish). Under the objective of sustainable exploitation, the MPA size required to ensure conservation is generally found to be smaller when using these models than the one predicted from simpler models. In the example of section 4 , a closure of four months in a zone covering $57 \%$ of the fishing ground of one métier (the reproduction zone of population 1) was sufficient on its own to restore the targeted population. Closing areas where fish aggregate seasonally results in sharp reductions of fishing mortality (Apostolaki et al. 2002; Pelletier and Magal 1996; Holland 2000; see also section 4.2), because MPA contributes not only to decreasing overall fishing pressure, but also to improve exploitation patterns. For instance, an MPA aimed at juvenile protection will decrease corresponding fishing mortality. 
Accepted for publication in Fish and Fisheries

In a spatially and seasonally explicit model, the distinction between reproduction and recruitment (in terms of areas and timing) is necessary for a realistic evaluation of fishing impact, because spawning areas and nurseries are generally located in segregated areas corresponding to different habitat requirements. Such a distinction is particularly relevant for assessing technical interactions such as those leading to discards of juvenile fish. In parallel, it permits considering a wider range of MPA designs to protect populations, e.g. designs aimed at protecting seasonally vulnerable population stages (Walters et al. 1993; Pelletier et al. 1996; ISIS-Fish). In this respect, a seasonal closure during recruitment may be as efficient at protecting the population as a permanent closure (see subsection 4.2).

The difficulty of estimating migration coefficients together with the sensitivity of population dynamics to these parameters is often put forward as an argument against developing spatially-explicit models. With regard to ontogenic migrations, this argument might hold less. Nurseries and spawning sites, as well as reproduction and recruitment times are relatively well identified for many fish populations. In addition, spawner migration and recruitment are often "en masse" movements, and the issue of precisely estimating corresponding migration coefficients is not so crucial as for coefficients linked to redistribution of stages in several areas.

In the light of our review and our experience with ISIS-Fish, it appears that population models for evaluating MPA impact and exploring design issues should accurately describe i) the relationship between spawning and recruitment including possible larval dispersion schemes; and ii) the spatial patterns of populations that influence fishing effort allocation, in particular at intermediate scales where population dynamics, effort dynamics and management are most likely to interfere with one another.

Accounting for the environmental influence of larval dispersion schemes in population dynamics models, remains an open and important issue (see Botsford et al. 1994; Stockhausen et al. 2000; Morgan and Botsford 2001). It is technically complex, because it requires coupling population dynamic models and hydrodynamic models that involve different scales and processes, and thus different modelling approaches.

Our discussion focused so far on population modelling, but several effects expected from MPA pertain to communities or ecosystems like biodiversity protection and changes in assemblage structure (Table 7). These changes generally occur at longer time-scales than effects such as restoration of targeted species and fisheries 
Accepted for publication in Fish and Fisheries

changes (see e.g. trophic cascades in Pinnegar et al. (2000) and Shears and Babcock (2003)). Reviewed population models (Table 4) as well as the ISIS-Fish model do not consider predator-prey interactions, and therefore cannot be used to evaluate shifts in community structure that could follow MPA implementation. Multispecies and ecosystem models (Table 5) are necessary for addressing these questions. But modelling trophic relationships is complex, and existing models cannot encompass demographic structures and ontogenic migrations at the population level (see section 2.1 for details). Therefore, they are poorly suited for exploring fisheries-related effects and MPA designs.

We believe that not all MPA effects may be investigated through a single tool, because of modelling limitations. We recommend that three kinds of models be used for MPA evaluation. First, population models focused on larval dispersion in relation to hydrodynamics are needed to identify critical timing or areas for the population to be restored or protected, and to evaluate MPA designs with respect to larval dispersion and settlement schemes. They may describe demographic structure (see Stockhausen et al. 2000), but they cannot detail exploitation features. Second, stage-structured spatially and seasonally explicit population models (whenever available information permits) are particularly suited for evaluating a variety of MPA designs, and comparing them with other management measures. They are easily coupled with exploitation models. They could also integrate results and hypotheses obtained from the first kind of model. Therefore, they may be used to address conservation issues at the species level and fisheries-related issues (including mixed fisheries issues), but not for long-term predictions because they assume that a number of biological parameters and processes remain unchanged throughout the simulation. In the end, they may provide a list of MPA designs and management scenarios that are desirable for sustainable exploitation and for protecting a number of species. Third, multispecies and ecosystem models should be used for investigating changes in community following the implementation of the MPA designs identified from the second kind of model. It is likely that some designs may be more easily investigated than others. For instance, seasonal closures or closures targeting certain activities may be difficult to parameterize in these models. However, permanent no-take zones which are preferred options when biodiversity protection is the primary goal can be tested. 


\subsection{Exploitation and management modelling}

We now focus on fisheries models that explicitly describe exploitation. The range of models proposed to capture exploitation and management dynamics is far more reduced than for populations, and spatiallyexplicit models for mixed fisheries are few (Sparre and Willman 1993; Walters and Bonfil 1999; Holland 2000; Punt et al. 2002; Sparre 2003; ISIS-Fish). Several bioeconomic models have been developed; they are mostly theoretical heuristic models where effort either has its own dynamics (endogeneous effort) following for instance a rent dissipation model, or it is estimated through the model under the assumption that economic rent is maximized.

A few general consequences resulting from MPA establishment may be listed. First, MPA appear as a desirable option only in overexploitation situations, i.e. if fishing mortality is initially high enough. Although often quoted in the papers, this should not be surprising since MPA are always designed to decrease fishing pressure. Thus, considering MPA for fisheries management purposes is only relevant in overexploited situations. In contrast, other policies can be designed to either increase or decrease fishing pressure. Moreover, because MPAs act as spawner and recruit reservoirs when properly designed, they may appear more efficient at addressing recruitment overfishing than growth overfishing.

Although benefits for resource conservation are quite general (see subsection 5.1), benefits for catch and even more so economic benefits to the fishery appear more questionable. Results largely differ among models, in terms of both optimal reserve size for sustainable rent and catch levels.

In addition, the literature review indicates that several important issues linked to exploitation and management are not presently fully addressed. First, existing models do not permit investigating a wide range of MPA designs. They mostly focus on no-take zones. Spatial restrictions of fishing for certain gears or fishing activities are rarely investigated (but see e.g. ECOSPACE and Martell et al. (2000)). Second, MPAs are seldomly compared to other policies. Likewise, combinations of MPAs with other management measures are almost never considered. Yet, its is acknowledged that MPA establishment must be accompanied by a reduction in fishing capacity (e.g. Guénette et al. (2000)), otherwise the necessary reserve size may be unrealistically large (e.g. Sladek Nowlis and Roberts 1999). Third, the behavioural response of fisher to policy implementation is almost 
Accepted for publication in Fish and Fisheries

never taken into account in policy evaluation, although it is known as an important factor for MPA performance, and for policy performance in general.

The exploitation model in ISIS-Fish is more detailed than in existing models of mixed fisheries, which rarely explicit fishing activities (see subsection 2.2). In ISIS-Fish, fishing activities are described by métiers at the month level, and by strategies at the year level. This description may be parameterized by the kind of data usually collected in documented fisheries (see subsection 5.3). The parameterization of métiers and strategies determines the allocation of fishing effort which may in turn change during a simulation through fishers' behaviour and particularly through their response to policy. An alternative to data-based parameterization of fishing effort is to encapsulate effort dynamics, e.g. to make effort endogeneous through a relationship, e.g. based on the assumption of optimal allocation. In this case, parameterization from real data is difficult, and we preferred a static effort allocation (in the absence of fisher's response) that may be estimated from data. Note also that encapsulating dynamics restricts the screening ability of a model.

A key issue in fisheries models is the relationship between fishing effort and fishing mortality. In ISIS-Fish, this relationship depends on the extent and duration of the spatial overlap between the fishing zone and the population zone, and fishing mortality is computed from fishing effort by assuming uniform distributions of abundance and effort over their respective zones. This relationship is central to ISIS-Fish, as it enables considering any number of population and fishing activities, with only computational constraints and it makes it possible to compute mortalities for all populations and all métiers, including incidental mortalities. Consequences of technical interactions inherent to mixed fisheries may then be investigated (see subsection 4.2). Finally, it makes it possible to have relatively a parsimonious number of zones for each population and each fishing activity. However, it requires that zones be carefully sized and delineated from fisheries data. In particular, the métier zone must be consistent with the zoning of the primary target populations, otherwise it would be unrealistic to assume a uniform distribution of effort over the métier zone.

With respect to management, policy options may be diverse and are explicitely modelled and parameterized in ISIS-Fish using a script language. This way, they may also be combined in a consistent manner. Fishers' response is modelled in the form of decision rules which are believed to be more appropriate to reflect possible 
Accepted for publication in Fish and Fisheries

behaviours arising from a set of conditions on the resources, on fishing alternatives and on policies. Note that in ISIS-Fish, decision rules may also be used to modify fishing effort allocation even in the absence of policy. Decision rules may for instance be constructed and parameterized from discrete choice random utility models such as those developed by Holland and Sutinen (1999) and Hutton et al. (2004). Spatial and seasonal representations of exploitation and management enable one to consider reallocation of fishing effort to other zones, métiers and strategies, and fishers' response may indeed affect most exploitation parameters. Thus, consequences of policies may be explored in a rather realistic way, and particularly those related to technical interactions and more generally to multispecies multifleet aspects.

\subsection{What kind of tool is needed for policy-screening ?}

To be helpful for fisheries management, a policy-screening tool should display several qualities, some of them pertaining to the underlying model, and the others to the tool itself.

As to the underlying model, it should be sufficiently detailed to capture the essence of fisheries dynamics with respect to the scenarios investigated. We should not "go to too much detailed models without stopping to ask whether the extra is necessary" (Walters et al. 1997). In the case of MPA assessment, spatially-explicit models are definitely required for both population and exploitation components (see subsections 5.1 and 5.2). Policy consequences in mixed fisheries are difficult to understand if spatial issues are not taken into account. Seasonal features should also be explicitly modelled when relevant to the fishery at hand, i.e. in many cases. In mixed fisheries, the exploitation model should contain the main components of fishing effort. Effort is the resultant of gear, time spent fishing and fishers' behaviour at both trip scale and year scale. Failing to account for these components restricts the range of policy options and associated fishers' responses that can be investigated. In addition, considering components of fishing effort is needed to account for costs that are specific to e.g. gears, fuel or crew salaries, and thus to build bioeconomic models for policy evaluation. Regarding management modelling, as acknowledged in the literature, fishers' response should be modelled as well and testing of combined policies should be made possible. 
Accepted for publication in Fish and Fisheries

Second, the model should be based on real data. Model construction should derive not only from expert knowledge but also from data analyses. Hence, population zones may be delineated from multivariate analyses (see e.g. Pelletier and Magal 1996; Verdoit et al. 2003) as well as fishing grounds (Pelletier and Ferraris 2000). Parameter estimation within spatial models is generally problematic because of the lack of detailed information with respect to model complexity. There have been some attempts to develop estimation procedures for population models (Maunder 2001; Begley and Howell 2004; Stefansson and Taylor 2004), but such approaches are not feasible for fisheries models, particularly for mixed fisheries models. One way to circumvent this issue to some extent is to ensure that parameters may be estimated by statistical analyses independently of the model and in a consistent way with respect to model equations. This approach is not fully rigourous from a statistical standpoint, but it is pragmatic. This is particularly appropriate for exploitation-related parameters in mixed fisheries. In ISIS-Fish, the choice of the exploitation model was based on both realism and consistency with the kind of information available to estimate corresponding parameters in documented fisheries (e.g. commercial logbook data, fishers interviews, observer data, etc.). Likewise, the spatial resolution of ISIS-Fish may be adapted to the level of knowledge and data availability to facilitate integration of available information about the fishery.

In addition to these desirable model features, policy-screening tools should display qualities linked to their utilization. They should be able to incorporate improved knowledge about the fishery and changes in some model assumptions, as the amount of uncertainty relative to most fisheries precludes the use of a unique model formulation and parameterization. For instance, the model of Walters and Bonfil (1999) and ISIS-Fish are designed to accommodate improved information on population dynamics as it becomes available. In the same line of thought, facilities for carrying out simulation designs and sensitivity analyses should be integrated into any software, as numerous simulations are required for policy-screening. Simulation designs must indeed involve combinations of policy designs, parameter values, and model assumptions to encompass a plausible range of "states of nature" for the fishery, and thereby warrant that results are not too dependent on certain parameter values and assumptions. Accommodating all these features results in software development that are costly in terms of both effort and time. Therefore, a tool should be applicable to several fisheries. In developing ISIS-Fish, we tried to address each of these issues : i) a database is attached to the model, so that changes in 
Accepted for publication in Fish and Fisheries

fishery description are easy and several fisheries may be entered; ii) several components of the model may be interactively coded and saved using a script language, e.g. growth, reproduction, selectivity and fishers' response; iii) user interfaces for running sensitivity analyses and simulation designs have been developed; and iv) the software was developed under a GNU General Public License ${ }^{4}$ and is freely available ${ }^{5}$. More details about i) and ii) may be found in Mahévas and Pelletier (2004). An application of iii) to a real fishery is presented in Drouineau et al. (unpublished findings ${ }^{6}$ ). Note that ISIS-Fish is deterministic, preventing from running stochastic simulations. Results of simulation designs are integrated in the form of probability distributions and interpreted through statistical analysis.

The results shown in section 4 illustrate the fact that assessing the performance of MPAs aimed at fisheries management might not be as simple as might be deduced from many models developed so far for this purpose. A majority of models are heuristic tools that provide interesting qualitative insight, but should not be used for quantitative predictions. At the other extreme, conventional fisheries models such as those used for stock assessment and simulation models aimed at policy analysis are in general not appropriate for MPA investigations (also pointed out by Holland 2003). Heuristic tools cannot be used to recommend general rules, such as a fraction of the fishery region to be closed in order to ensure sustainability, unless it is clearly specified that the prescription is purely indicative and that further studies are required to obtain a more realistic model and reliable results with respect to the specificities of the fishery at stake. As underlined by Agardy et al. (2003), "the prescription of simplistic solutions to marine conservation problems may ultimately impede the development of MPA for coastal management”.

In the light of the large number of models published in recent years, the use of mathematical models to evaluate the impact of MPA has been challenged by Willis et al. (2003). According to these authors, "the proliferation of models has resulted in model assumptions evolving into accepted paradigms". We believe that models are indispensable to evaluate MPA consequences at the scale of fisheries and ecosystems. They are not just "ideas" (Willis et al. 2003). Rather than disposing of all models, we advocate the development and use of models that i) achieve a trade-off between parsimony and complexity ; ii) are parameterized from and confronted to real data.

\footnotetext{
${ }^{4}$ http://www.gnu.org/copyleft/gpl.html

${ }_{6}^{5} \mathrm{http} / \mathrm{www}$.ifremer.fr/ISIS-Fish ; http://isis-fish.labs.libre-entreprise.org/

${ }^{6}$ paper in revision, available from the corresponding author
} 
Accepted for publication in Fish and Fisheries

In addition, we recommend that policy evaluation (including MPAs) relies on several modelling tools used sequentially or iteratively, because not all consequences may be investigated through a single tool.

\section{Acknowledgements}

The authors warmly thank Ray Hilborn, Ana Parma, Sylvie Guénette and Verena Trenkel for comments and suggestions on an earlier draft of this paper. Two anonymous reviewers are gratefully acknowledged. Thanks to Chuck Hollingworth for additional detailed comments .

The development of ISIS-Fish was made possible through IFREMER contracts 99/210448, 99/210500 01/210676, 02/210898, 03/210136 and 04/210316. Additional support was provided by the Programme National pour l'Environnement Côtier/Action de Recherche Thématique 4. 
Accepted for publication in Fish and Fisheries

\section{References}

Acosta, C. A. (2002) Spatially-explicit dispersal dynamics and equilibrium population sizes in marine harvest refuges. ICES Journal of marine Science, 59, 458-468.

Agardy, M. T. (1994) Advances in marine conservation : the role of marine protected areas. Trends in Ecology and Evolution, 9, 267-270.

Agardy, T., Bridgewater, P., Crosby, M. P., Day, J. W., Dayton, P. K., Kenchington, R., Laffoley, D., McConney, P., Murray, P. A., Parks, J. E. and Peau, L. (2003) Dangerous targets ? Unresolved issues and ideological clashes around marine protected areas. Aquatic Conservation : Marine and Freshwater Ecosystems, 13, 353-367.

Allen, P. M. and McGlade, J. M. (1986) Dynamics of discovery and exploitation : the case of the scotian shelf groundfish fisheries. Canadian Journal of Fisheries and Aquatic Sciences, 43, 1187-1200.

Anderson, L. G. (2002) A bioeconomic analysis of marine reserves. Natural Resource Modeling, 15, 311-334.

Anonymous (1991) Report of the working group on methods of fish stock assessments. ICES CM 1991/A 25, $146 \mathrm{pp}$.

Anonymous (1997) Shelf Edge Fisheries and Oceanography Study (SEFOS). Final Report of the Europan Union AIR Programme. AIR2-CT93-1105, 88 pp.

Anonymous (1999) Report of the workshop on the evaluation of the plaice box. ICES CM 1999/D 6, 28 pp.

Apostolaki, P., Milner-Gulland, E. J., McAllister, M. K. and Kirkwood, G. P. (2002) Modelling the effects of establishing a marine reserve for mobile fish species. Canadian Journal of Fisheries and Aquatic Sciences, 59, 405-415.

Arias-Gonzáles, J. E. (1998) Trophic models of protected and unprotected coral reef ecosystems in the South of the Mexican Carribean. Journal of Fish Biology, 53, 236-255.

Attwood, C. G. and Bennett, B. A. (1995) Modelling the effect of marine reserves on the recreational shorefishery of the south-western Cape, South Africa. South African Journal of marine Science, 16, 227-240.

Beattie, A., Sumaila, U. R., Christensen, V. and Pauly, D. (2002) A model for the bioeconomic evaluation of marine protected area size and placement in the North Sea. Natural Resource Modeling, 15, 413-437. 
Accepted for publication in Fish and Fisheries

Begley, J. and Howell, D. (2004) An overview of Gadget, the globally applicable area-disaggregated general ecosystem toolbox. ICES CM 2004/FF 13, 16 pp.

Beverton, R. J. H. and Holt, S. J. (1957) On the dynamics of exploited fish populations., Chapman \& Hall, London.

Biseau, A. and Gondeaux, E. (1988) Apport des méthodes d'ordination en typologie des flottilles. Journal du Conseil international pour l'Exploration de la Mer, 44, 286-296.

Boncoeur, J., Alban, F., Guyader, O. and Thébaud, O. (2002) Fish, fishers, seals and tourists: economic consequences of creating a marine reserve in a multi-species, multi-activity context. Natural Resource Modeling, 15, 387-411.

Botsford, L. W., Quinn, J. F., Wing, S. R. and Brittnacher, J. G. (1993) Rotating spatial harvest of a benthic invertebrate, the red sea urchin, (Strongylocentrotus franciscanus). In: Management Strategies for Exploited Fish Populations (Proceedings of the International Lowell Wakefield Fisheries Symposium, Anchorage, 21-24 ${ }^{\text {th }}$ oct., 1993). Kruse, G. H., Eggers, D. M., Marasco, R. J., Pautzke, C. and Quinn II, T. J. eds., Alaska Sea Grant AK-SG-93-02, Anchorage, pp. 409-428.

Botsford, L. W., Moloney, C. L., Hastings, A., Largier, J. L., Powell, T. M., Higgins, K. and Quinn, J. F. (1994) The influence of spatially and temporally varying oceanographic conditions on meroplanktonic metapopulations. Deep-Sea Research II, 41, 107-145.

Brown, G. and Roughgarden, J. (1997) A metapopulation model with private property and a common pool. Ecological Economics, 22, 65-71.

Caddy, J. F. (1975) Spatial model for an exploited shellfish population, and its application to the Georges Bank scallop fishery. Journal of Fish Resource Board, Canada, 32, 1305-1328.

Campbell, H. F. and Hand, A. J. (1999) Modeling the spatial dynamics of the U.S. purse-seine fleet operating in the western Pacific tuna fishery. Canadian Journal of Fisheries and Aquatic Sciences, 56, 1266-1277.

Carr, M. H. and Reed, D. C. (1992) Conceptual issues relevant to marine harvest refuges : examples from temperate reef fishes. Canadian Journal of Fisheries and Aquatic Sciences, 50, 2019-2028.

Charnov, E. L. (1976) Optimal foraging, the marginal value theorem. Theoretical Population Biology, 9, 129136. 
Accepted for publication in Fish and Fisheries

Christensen, S. and Lassen, H. (1996) Optimal management of the Iceland-Greenland transboundary cod stock. Journal of Northwest Atlantic Fishery Science, 19, 21-29.

Christensen, V. and Pauly, D. (1992) ECOPATH II : a software for balancing steady-state models and calculating network characteristics. Ecological Modelling, 61, 169-185.

Crowder, L. B., Lyman, S. J., Figueira, W. F. and Priddy, J. (2000) Source-sink population dynamics and the problem of siting marine reserves. Bulletin of Marine Science, 66, 799-820.

Dahlgren, C. P. and Sobel, J. (2000) Designing a Dry Tortugas ecological reserve : How big is big enough ? ... To do what? Bulletin of Marine Science, 66, 707-719.

De Figueiredo, M. and Thomas, H. J. (1967) Nephrops norvegicus (L., 1758) leach - a review. Oceanography and Marine Biology Annual Review, 5, 371-407.

DeMartini, E. E. (1993) Modeling the potential of fishery reserves for managing Pacific coral reef fishes. Fishery Bulletin, 91, 414-427.

Die, D. J. and Watson, R. A. (1992) A per-recruit simulation model for evaluating spatial closures in an Australian penaeid fishery. Aquatic Living Resources, 5, 145-153.

Dorn, M. W. (2001) Fishing behavior of factory trawlers : a hierarchical model of information processing and decision making. ICES Journal of Marine Science 58:238-252.

Doubleday, W. G. (1975) Harvesting in matrix population models. Biometrics, 31, 189-200.

Eales, J. and J. E. Wilen (1986) An examination of fishing location choice in the pink shrimp fishery. Marine Resource Economics 2:331-351.

Fahrig, L. (1993) Effect of fish movement and fleet spatial behavior on management of fish substocks. Natural Resource Modelling, 7, 37-56.

Fretwell, S. D. and Lucas, H. L. (1970) On territorial behavior and other factors influencing habitat distribution in birds. Acta Biotheoretica, 19, 16-36.

Gendron, L., and J. C. Brêthes (2002) Simulations of the impact of different temporal and spatial allocations of fishing effort in fishing mortality in a lobster (Homarus americanus) fishery. Canadian Journal of Fisheries and Aquatic Sciences 59:899-909. 
Accepted for publication in Fish and Fisheries

Gerber, L. R., Botsford, L. W., Hastings, A., Possingham, H. P., Gaines, S. D., Palumbi, S. R. and Andelman, S.

(2003) Population models for marine reserve design : a retrospective and prospective synthesis. Ecological Applications, 13, S47-S64.

Gillis, D. M., R. M. Peterman, and A. V. Tyler (1993) Movement dynamics in a fishery : application of the ideal free distribution to spatial allocation of effort. Can. J. Fish. Aquat. Sci. 50:323-333.

Goh, B. S. (1977) Stability in a stock-recruitment model of an exploited fishery. Mathematical Bioscences., 33, $359-372$.

Gordon, H. S. (1954) The economic theory of a common property resource : the fishery. Journal of Political Economy, 62, 124-142.

Guénette, S. and Pitcher, T. J. (1999) An age-structured model showing the benefits of marine reserves in controlling overexploitation. Fisheries Research, 39, 295-303.

Guénette, S., Lauck, T. and Clarck, C. (1998) Marine reserves: from Beverton and Holt to the present. Reviews in Fish Biology and Fisheries, 8, 251-272.

Guénette, S., Pitcher, T. J. and Walters, C. J. (2000) The potential of marine reserves for the management of Northern cod in Newfoundland. Bulletin of Marine Science, 66, 831-852.

Hall, D. L., Hilborn, R., Stocker, M. and Walters, C. J. (1988) Alternative harvest strategies for Pacific herring. Canadian Journal of Fisheries and Aquatic Sciences, 45, 888-897.

Hannesson, R. (1998) Marine reserves : what would they accomplish ? Marine Resource Economics, 13, 159170.

Hannesson, R. (2002) The economics of marine reserves. Natural Resource Modeling, 15, 273-290.

Hanski, I. A. and Gilpin, M. E. (eds.) (1997) Metapopulation biology, ecology, genetics, and evolution. Academic Press, London, 512 pp.

Hastings, A. and Botsford, L. W. (1999) Equivalence in yield from marine reserves and traditional fisheries management. Science, 284, 1537-1538.

Hastings, A. and Botsford, L. W. (2003) Comparing designs of marine reserves for fisheries and for biodiversity. Ecological Applications, 13, S65-S70. 
Accepted for publication in Fish and Fisheries

Hilborn, R. (1985) Fleet dynamics and individual variation : why some people catch more fish than others.

Canadian Journal of Fisheries and Aquatic Sciences, 42, 2-13.

Hilborn, R. (2004) Ecosystem-based fisheries management : the carrot or the stick? Marine Ecology Progress Series, 274, 275-278.

Hilborn, R. and Ledbetter, M. (1979) Analysis of the british columbia salmon purse-seine fleet : dynamics of movement. Journal of Fish Resource Board, Canada, 36, 384-391.

Hilborn, R. and Ledbetter, M. (1985) Determinants of catching power in the british columbia salmon purse seine fleet. Canadian Journal of Fisheries and Aquatic Sciences, 42, 51-56.

Hilborn, R. and Walters, C. J. (1987) A general model for simulation of stock and fleet dynamics in spatially heterogeneous fisheries. Canadian Journal of Fisheries and Aquatic Sciences, 44, 1366-1369.

Holland, D. and Maguire, J. J. (2003) Optimal effort controls for the multispecies groundfish complex in New England: what might have been. Canadian Journal of Fisheries and Aquatic Sciences, 60, 159-170.

Holland, D. S. (2000) A bioeconomic model of marine sanctuaries on Georges Bank. Canadian Journal of Fisheries and Aquatic Sciences, 57, 1307-1319.

Holland, D. S. (2002) Integrating marine protected areas into models for fishery assessment and management. Natural Resource Modeling, 15, 369-386.

Holland, D. S. (2003) Integrating spatial management measures into traditional fishery management systems : the case of the Georges Bank multispecies groundfish fishery. ICES Journal of marine Science, 60, 915929.

Holland, D. S. and Brazee, R. J. (1996) Marine reserves for fisheries management. Marine Resource Economics, 11, 157-171.

Holland, D. S. and Sutinen, J. G. (1999) An empirical model of fleet dynamics in New England trawl fisheries. Canadian Journal of Fisheries and Aquatic Sciences, 56, 253-264.

Horwood, J. W., Nichols, J. H. and Milligan, S. (1998) Evaluation of closed areas for fish stock conservation. Journal of Applied Ecology, 35, 893-903.

Hutton T., S. Mardle, S. Pascoe, and R. Clark (2004) Modelling fishing location choice within mixed fisheries : English North Sea beam trawlers in 2000 and 2001. ICES Journal of marine Science 61:1443-1452. 
Accepted for publication in Fish and Fisheries

Jones, R. (1961) The assessment of the long term effects of changes in gear selectivity and fishing effort. Marine Research Scotland 2, 19 pp.

Kelleher, G. and Kenchington, R. (1992) Guidelines for establishing marine protected areas. A Marine Conservation and Development Report. IUCN vii+79 pp.

Laloë, F. and Samba, A. (1991) A simulation model of artisanal fisheries in Senegal. ICES marine Science Symposium, 193, 281-286.

Laloë, F., Pech, N., Sabatier, R. and Samba, A. (1998) Model identification for flexible multifleet-multispecies fisheries. A simulation study. Fisheries Research, 37, 193-202.

Lauck, T., Clark, C. W., Mangel, M. and Munro, G. R. (1998) Implementing the precautionary principle in fisheries management through the implementation of marine reserves. Ecological Applications, 8, 572578.

Laurec, A., Biseau, A. and Charuau, A. (1991) Modelling technical interactions. ICES marine Science Symposium, 193, 225-236.

Lebreton, J. D. (1996) Demographic models for subdivided populations : the renewal equation approach. Theoretical Population Biology, 49, 291-313.

Levin, S. A. and Goodyear, C. P. (1980) Analysis of an age-structured fishery model. Journal of Mathematical Biology, 9, 245-274.

Levins, R. (1966) The strategy of model building in population biology. American Scientist, 54, 421-431.

Levins, R. A. (1970) Extinction. Journal of the American Mathematical Society, 2, 77-107.

Lewy, P. and Vinther, M. (1994) Identification of Danish North Sea trawl fisheries. ICES Journal of marine Science, 51, 263-272.

Lundberg, P. L. and Jonzen, N. (1999) Spatial population dynamics and the design of marine reserves. Ecology Letters, 2, 129-134.

Mace, P. M. (1994) Relationships between common biological reference points used as thresholds and targets of fisheries management strategies. Canadian Journal of Fisheries and Aquatic Sciences, 51, 110-122. 
Accepted for publication in Fish and Fisheries

Mahévas, S. and Trenkel, V. (2002) Utilisation de modèles mixtes pour décrire la distribution spatio-temporelle du temps de pêche de la flottille française en mer Celtique. Journal de la Société Française de Statistique, 143, 177-186.

Mahévas, S. and Pelletier, D. (2004) ISIS-Fish, a generic and spatially explicit simulation tool for evaluating the impact of management measures on fisheries dynamics. Ecological Modelling, 171, 65-84.

Man, A., Law, R. and Polunin, N. V. C. (1995) Role of marine reserves in recruitment to reef fisheries: a metapopulation model. Biological Conservation, 71, 197-204.

Mangel, M. (1998) No-take areas for sustainability of harvested species and a conservation invariant for marine reserves. Ecology Letters, 1, 87-90.

Mangel, M. (2000a) Trade-offs between fish habitat and fishing mortality and the role of reserves. Bulletin of Marine Science, 66, 663-674.

Mangel, M. (2000b) On the fraction of habitat allocated to marine reserves. Ecology Letters, 3, 15-22.

Mangel, M. (2000c) Irreducible uncertainties, sustainable fisheries and marine reserves. Evolutionary Ecology Research, 2, 547-557.

Marchal, P. and Horwood, J. (1996) Long-term targets for the Celtic Sea mixed-species multi-métiers fisheries. Aquatic Living Resources, 9, 81-94.

Martell, S. J. D., Walters, C. J. and Wallace, S. S. (2000) The use of marine protected areas for conservation of lingcod (Ophiodon elongatus). Bulletin of Marine Science, 66, 729-743.

Martell, S. J. D., Essington, T., Lessard, B., Kitchell, J. F., Walters, C. J. and Boggs, C. H. (2005) Interactions of productivity, predation risk, and fishing effort in the efficacy of marine protected areas for the Central Pacific. Canadian Journal of Fisheries and Aquatic Sciences 62, 1320-1336.

Maunder, M. (2001) Integrated tagging and catch-at-age analysis (ITCAAN) : model development and simulation testing. In: Spatial Processes and Management of Marine Populations. (Proceedings of the $17^{\text {th }}$ Lowell Wakefield Fisheries Symposium, Anchorage, 27-30 $0^{\text {th }}$ oct., 2001). Kruse, G. H., Bez, N., Booth, T., Dorn, M., Hills, S., Lipcius, R., Pelletier, D., Roy, C., Smith, S. and S., Witherell eds., University of Alaska Sea Grant, AK-SG-00-04, Fairbanks, Anchorage, pp. 123-146. 
Accepted for publication in Fish and Fisheries

Maury, O. and Gascuel, D. (1999) SHADYS ('simulateur halieutique de dynamiques spatiales'), a GIS based numerical model of fisheries. Example application : the study of a marine protected area. Aquatic Living Resources, 12, 77-88.

McClanahan, T. R. (1995) A coral-reef ecosystem-fisheries model : impact of fishing intensity and catch selection on reef structure and process. Ecological Modelling, 80, 1-19.

McClanahan, T. R. and Sala, E. (1997) A Mediterranean rocky-bottom ecosystem fisheries model. Ecological Modelling, 104, 145-164.

Meester, G. A., Ault, J. S., Smith, S. G. and Mehrotra, A. (2001) An integrated simulation modeling and operation research approach to spatial management decision making. Sarsia, 86, 543-558.

Mesnil, B. and Shepherd, J. G. (1990) A hybrid age- and length-structured model for assessing regulatory measures in multiple-species, multiple-fleet fisheries. Journal du Conseil international pour l'Exploration de la Mer, 47, 115-132.

Morgan, L. E. and Botsford, L. W. (2001) Managing with reserves : modeling uncertainty in larval dispersal for a sea urchin fishery. In: Spatial Processes and Management of Marine Populations (Proceedings of the $17^{\text {th }}$ Lowell Wakefield Fisheries Symposium, Anchorage, 27-30 $0^{\text {th }}$ oct., 2001). Kruse, G. H., Bez, N., Booth, T., Dorn, M., Hills, S., Lipcius, R., Pelletier, D., Roy, C., Smith, S. and S., Witherell eds., University of Alaska Sea Grant, AK-SG-00-04, Fairbanks, Anchorage, pp. 667-681.

Murawski, S. A. (1984) Mixed-species yield-per-recruitment analyses accounting for technological interactions. Canadian Journal of Fisheries and Aquatic Sciences, 41, 897-916.

Murawski, S. A. and Finn, J. T. (1986) Optimal effort allocation among competing mixed-species fisheries, subject to fishing mortality constraints. Canadian Journal of Fisheries and Aquatic Sciences, 43, 90-100.

Ogden, J. C. and Quinn, T. P. (1984) Migration in coral reef fishes : ecological significance and orientation mechanisms. In: Mechanisms of migration in fishes. (eds. McCleave, J. D., Arnold, G. P., Dodson, J. J. and Neill, W. H.), Plenum Press, London, pp. 293-308.

Parrish, R. (1999) Marine reserves for fisheries management : why not. California Cooperative Oceanic Fisheries Investigations Reports, 40, 77-86. 
Accepted for publication in Fish and Fisheries

Pastoors, M. A., Rijnsdorp, A. D. and Van Beck, F. A. (2000) Effect of a partially closed area in the North Sea ("plaice box") on stock development of plaice. ICES Journal of marine Science, 57, 1014-1022.

Pelletier, D. and Magal, P. (1996) Dynamics of a migratory population under different fishing effort allocation schemes in time and space. Canadian Journal of Fisheries and Aquatic Sciences, 53, 1186-1199.

Pelletier, D. and Ferraris, J. (2000) A multivariate approach for defining fishing tactics from commercial catch and effort data. Canadian Journal of Fisheries and Aquatic Sciences, 57, 51-65.

Pelletier, D., Mahévas, S., Poussin, B., Bayon, J., André, P. and Royer, J. C. (2001) A conceptual model for evaluating the impact of spatial management measures on the dynamics of a mixed fishery. In: Spatial Processes and Management of Marine Populations. (Proceedings of the $17^{\text {th }}$ Lowell Wakefield Fisheries Symposium, Anchorage, 27-30 $0^{\text {th }}$ oct., 2001). Kruse, G. H., Bez, N., Booth, T., Dorn, M., Hills, S., Lipcius, R., Pelletier, D., Roy, C., Smith, S. and S., Witherell eds., University of Alaska Sea Grant, AKSG-00-04, Fairbanks, Anchorage, pp. 53-66.

Pelletier, D., Garcia-Charton, J. A., Ferraris, J., David, G., Thébaud, O., Letourneur, Y., Claudet, J., Amand, M., Kulbicki, M. and Galzin, R. (2005) Designing indicators for evaluating the impact of Marine Protected Areas on coral reef ecosystems : a multidisciplinary standpoint. Aquatic Living Resources, 18, 15-33.

Pezzey, J. C. V., Roberts, C. M. and Urdal, B. T. (2000) A simple bioeconomic model of a marine reserve. Ecological Economics, 33, 77-91.

Pikitch, E. K. (1987) Use of mixed-species yield-per-recruit model to explore the consequences of various management policies for the Oregon flatfish fishery. Canadian Journal of Fisheries and Aquatic Sciences, 44, 349-359.

Pinnegar J. K., N. V. C. Polunin, P. Francour, F. Badalamenti, R. Chemello, M.-L. Harmelin-Vivien, B. Hereu, M. Milazzo, M. Zabala, G. D'Anna, and C. Pipitone (2000) Trophic cascades in benthic marine ecosystems : lessons for fisheries and protected-area management. Environmental Conservation 27:179200.

Pitcher, T. J., Buchary, E. A. and Hutton, T. (2002) Forecasting the benefits of no-take human-made reefs using spatial ecosystem simulation. ICES Journal of marine Science, 59, S17-S26.

Polacheck, T. (1990) Year around closed areas as a management tool. Natural Resource Modeling, 4, 327-354. 
Accepted for publication in Fish and Fisheries

Polovina, J. J. (1984) Model of a coral reef ecosystem I. The ECOPATH model and its application to French Frigate Shoals. Coral Reefs, 3, 1-11.

Poulard, J. C. and Léauté, J. P. (2002) Interaction between marine populations and fishing activities : temporal patterns of landings of La Rochelle trawlers in the Bay of Biscay. Aquatic Living Resources, 15, 197210.

Punt, A. E., Smith, A. D. M. and Cui, G. (2002) Evaluation of management tools for Australia's South East fishery - 1. Modelling the South East fishery taking account of technical interactions. Marine Freshwater Research, 53, 615-629.

Quinn, J. F., Wing, S. R. and Botsford, L. W. (1993) Harvest refugia in marine invertebrate fisheries : models and applications to the red sea urchin, Strongylocentrotus franciscanus. American Zoology, 33, 537-550.

Rijnsdorp, A. D. and Pastoors, M. A. (1995) Modelling the spatial dynamics of North Sea plaice (Pleuronectes platessa L.) based on tagging data. ICES Journal of marine Science, 52, 963-980.

Rijnsdorp, A. D., G. J. Piet, and J. J. Poos (2001) Effort allocation of the Dutch beam trawl fleet in response to a temporary closed area in the North Sea. ICES CM 2001/N 1, 17 pp.

Rijnsdorp, A. D., P. L. van Mourik Broekman, and E. G. Visser (2000a) Competitive interactions among beam trawlers exploiting local patches of flatfish in the North Sea. ICES Journal of Marine Science 57:894902.

Rijnsdorp, A. D., D. W., M. Hooyer, and M. A. Pastoors (2000b) Effects of fishing power and competitive interactions among vessels on the effort allocation at the trip level of the Dutch beam trawl fleet. ICES Journal of Marine Science 57:927-937.

Rodwell, L. D., Barbier, E. B., Roberts, C. M. and McClanahan, T. R. (2002) A bioeconomic analysis of tropical marine reserves-fishery linkages : Mombasa Marine National Park. Natural Resource Modeling, 15, 183-197.

Rowley, R. J. (1994) Marine reserves in fisheries management. Aquatic Conservation : Marine and Freshwater Ecosystems, 4, 233-254.

Salas, S. and Gaertner, D. (2004) The behavioural dynamics of fishers: management implications. Fish and Fisheries, 5, 153-167. 
Accepted for publication in Fish and Fisheries

Salthaug, A. and Aanes, S. (2003) Catchability and the spatial distribution of fishing vessels. Canadian Journal of Fisheries and Aquatic Sciences, 60, 259-268.

Sanchirico, J. N. and Wilen, J. E. (1999) Bioeconomics of spatial exploitation in a patchy environment. Journal of Environmental Economics and Management, 37, 129-150.

Sanchirico, J. N. and Wilen, J. E. (2001a) The impact of marine reserves on limited-entry fisheries. In: Economics of protected areas. (eds. Sumaila, U. R., Alder, J. and Weingartner, G.), Fisheries Centre, Vancouver, pp. 212-222.

Sanchirico, J. N. and Wilen, J. E. (2001b) A bioeconomic model of marine reserve creation. Journal of Environmental Economics and Management, 42, 257-276.

Seber, G. A. F. (1989) Estimation of Animal Abundance and related Parameters., $2^{\text {nd }}$ ed. Griffin \& Co. Ltd., London.

Seijo, J. C. and Defeo, O. (1994) Dynamics of resource and fishermen behaviour in coastal invertebrate fisheries. In: Proceedings of the $6^{\text {th }}$ Conference of the International Institute of Fisheries Economics and Trade, Paris, 6-9 $9^{\text {th }}$ July 1992 (eds. Antona, E., Catanzano, J. and Sutinen, J. G.), IFREMER, Paris, pp. 209222.

Seijo, J. C., Caddy, J. F. and Euan, J. (1993) SPATIAL : Space-time dynamics in marine fisheries, a software package for sedentary species, FAO, Rome.

Shears, N. T., and R. C. Babcock (2003) Continuing trophic cascade effects after 25 years of no-take marine reserve protection. Marine Ecology Progress Series 246:1-16.

Shin, Y. J. (2001) Simulation of the effects of marine protected areas on yield and diversity using a multispecies, spatially-explicit, individual-based model. In: Spatial Processes and Management of Marine Populations (Proceedings of the $17^{\text {th }}$ Lowell Wakefield Fisheries Symposium, Anchorage, 27-30 ${ }^{\text {th }}$ Oct., 2001). Kruse, G. H., Bez, N., Booth, T., Dorn, M., Hills, S., Lipcius, R., Pelletier, D., Roy, C., Smith, S. and S., Witherell eds., University of Alaska Sea Grant, AK-SG-00-04, Fairbanks, Anchorage, pp. 627-642.

Shin, Y. J. and Cury, P. (2001) Exploring community dynamics through size-dependent trophic interactions using a spatialized individual-based model. Aquatic Living Resources, 14, 65-80. 
Accepted for publication in Fish and Fisheries

Simberloff, D. (1988) The contribution of population and community biology to conservation science. Annual Review of Ecology and Systematics, 19, 473-511.

Sladek Nowlis, J. (2000) Short- and long-term effects of three fishery-management tools on depleted fisheries. Bulletin of Marine Science, 66, 651-662.

Sladek Nowlis, J. and Roberts, C. M. (1999) Fisheries benefits and optimal design of marine reserves. Fishery Bulletin, 97, 604-616.

Sparre, P. J. (2003) An EXCEL-based software toolbox for stochastic fleet-based forecast. ICES CM 2003/V 7 , $48 \mathrm{pp}$.

Sparre, P. J. and Willmann, R. (1993) Software for bio-economic analysis of fisheries, BEAM 4. Analytical bioeconomic simulation of space-structured multispecies and multifleet fisheries. Vol. 1 : Description of the model. Vol. 2: User's manual. FAO Computerized Information Series Fisheries. 186+46 pp.

St Mary, C. M., Osenberg, C. W., Frazer, T. K. and Lindberg, W. J. (2000) Stage structure, density dependence and the efficacy of marine reserves. Bulletin of Marine Science, 66, 675-690.

Stefansson, G. and Taylor, L. (2004) Verifying consistency when fitting complex statistical models to multiple data sets with applications to fish population dynamics and fisheries. ICES CM 2004/FF 26, 14 pp.

Stockhausen, W. T., Lipcius, N. and Hickey, B. M. (2000) Joint effects of larval dispersal, population regulation, marine reserve design, and exploitation on production and recruitment in the Caribbean spiny lobster. Bulletin of Marine Science, 66, 957-990.

Sumaila, U. R. (1998) Protected marine reserves as fisheries management tools: a bioeconomic analysis. Fisheries Research, 37, 287-296.

Sumaila, U. R. (2002) Marine protected areas performance in a model of the fishery. Natural Resource Modeling, 15, 439-451.

Sumaila, U. R. and Charles, A. T. (2002) Economic models of marine protected areas : an introduction. Natural Resource Modeling, 15, 261-272.

Sumaila, U. R., Guénette, S., Alder, J. and Chuenpagdee, R. (2000) Addressing ecosystem effects of fishing using marine protected areas. ICES Journal of marine Science, 57, 752-760. 
Accepted for publication in Fish and Fisheries

Supriatna, A. K. and Possingham, H. P. (1998) Optimal harvesting for a predator-prey metapopulation. Bulletin of Mathematical Biology, 60, 49-65.

Tanaka, E., Tanaka, S. and Hasegawa, A. (1991) Simulation of fishermen's selection of fishing areas for stock management. Nippon Suisan Gakkaishi, 57, 1417-1426.

Tuck, G. N. and Possingham, H. P. (1994) Optimal harvesting strategies for a metapopulation. Bulletin of Mathematical Biology, 56, 107-127.

Tuck, G. N. and Possingham, H. P. (2000) Marine protected areas for spatially-structured exploited stocks. Marine Ecology Progress Series, 192, 89-101.

Ulrich, C., Le Gallic, B. and Dunn, M. R. (1999) Bioeconomic modelling of English Channel fisheries and their technical interactions : presentation of the simulation model BECHAMEL. ICES CM 1999/S 4, 21 pp.

Ulrich, C., Pascoe, S., Sparre, P. J., De Wilde, J. W. and Marchal, P. (2002) Influence of trends in fishing power on bioeconomics in the North Sea flatfish fishery regulated by catches or by effort quotas. Canadian Journal of Fisheries and Aquatic Sciences, 59, 829-843.

Verdoit, M., Pelletier, D. and Bellail, R. (2003) Are commercial logbook and scientific CPUE data useful for characterizing the spatial and seasonal distribution of exploited populations ? The case of the Celtic Sea whiting. Aquatic Living Resources, 16, 467-485.

Verdoit-Jarraya, M. (2003) Caractérisation et modélisation de la dynamique spatiale et saisonnière de populations démersales et benthiques exploitées de la Mer Celtique. PhD Thesis, University of Paris VI, 228 pages.

Vignaux, M. (1996a) Analysis of vessel movements and strategies using commercial catch and effort data from the New Zealand hoki fishery. Canadian Journal of Fisheries and Aquatic Sciences, 53, 2126-2136.

Vignaux, M. (1996b) Analysis of spatial structure in fish distribution using commercial catch and effort data from the New Zealand hoki fishery. Canadian Journal of Fisheries and Aquatic Sciences, 53, 963-973.

Walters, C. (2000) Impacts of dispersal, ecological interactions and fishing effort dynamics on efficacy of marine protected areas : how large should protected areas be ? Bulletin of Marine Science, 66, 745-757.

Walters, C., Christensen, V. and Pauly, D. (1997) Structuring dynamic models of exploited ecosystems from trophic mass-balance assessments. Reviews in Fish Biology and Fisheries, 7, 139-172. 
Accepted for publication in Fish and Fisheries

Walters, C., Pauly, D. and Christensen, V. (1999) Ecospace : prediction of mesoscale spatial patterns in trophic relationships of exploited ecosystems, with emphasis on the impacts of marine protected areas. Ecosystems, 2, 539-554.

Walters, C. J. and Bonfil, R. (1999) Multispecies spatial assessment models for the Bristish Columbia groundfish trawl fishery. Canadian Journal of Fisheries and Aquatic Sciences, 56, 601-628.

Walters, C. W., Hall, N., Brown, R. and Chubb, C. (1993) Spatial model for the population dynamics and exploitation of the western australian rock lobster, Panulirus cygnus. Canadian Journal of Fisheries and Aquatic Sciences, 50, 1650-1662.

Watson, R., Alder, J. and Walters, C. (2000) A dynamic mass-balance model for marine protected areas. Fish and Fisheries, 1, 94-98.

Whitmarsh, D. J. and Young, J. A. (1985) Management of the UK mackerel fisheries. Marine Policy, 9, 220236.

Wilen, J. E., M. D. Smith, D. Lockwood, and L. W. Botsford (2002) Avoiding surprises : incorporating fisherman behavior into management models. Bulletin of Marine Science 70:553-575.

Willis, T. J., Millar, R. B., Babcock, R. C. and Tolimieri, N. (2003) Burdens of evidence and the benefits of marine reserves : putting Descartes before des horse ? Environmental Conservation, 30, 97-103. 


\section{Appendix 1}

\section{Migration, growth and reproduction modelling}

In the case of an age-structured population, animals change ages at the beginning of each year, and the last age group may be a plus group. In the case of length-structured populations, animals may change classes at the beginning of each month, as a function of length class definition and growth. In the case of stage-structured populations, e.g. two-stage models distinguishing mature and immature animals, individuals may change stages at the beginning of each month as a function of growth and maturity ogive. Seasonal variations in growth may be accounted for since the proportion of fish changing classes at a given month depends on population season. For each population season, we defined a block diagonal matrix $\mathbf{C C}_{\text {season }}$ of dimension $n \times$ NbClass :

$$
\mathrm{CC}_{\text {season }}=\left[\begin{array}{ccccc}
C C_{Z 1} & \cdots & 0 & \cdots & 0 \\
\vdots & \ddots & \vdots & \ddots & \vdots \\
0 & \cdots & C C_{Z i} & \cdots & 0 \\
\vdots & \ddots & \vdots & \ddots & \vdots \\
0 & \cdots & 0 & \cdots & C C_{Z n}
\end{array}\right]
$$

where each block $\mathbf{C C}_{\mathbf{Z i}}$ is a square matrix of dimension $N$ bClass and of element $c C_{i j}$ the proportion of class $j$ growing to class $i$ at the beginning of each month of the season in zone $\mathbf{Z i}$. Note that $c C_{i j}$ is zero for $\mathrm{i}<\mathrm{j}, \quad \sum_{j=1}^{\mathrm{NbClass}} c C_{i j}=1$, and $c C_{N b C l a s s, N b C l a s s}=1$ in case of a plus group. Class changes are thus the same for all population zones, but could be easily made zone-dependent given the matrix formulation.

Migration processes include migrations between population zones, emigration outside of the fishery region, and immigration into the region. Migration and emigration are modelled by age-specific migration rates, whereas immigration is described by an abundance vector. At each time step, migration processes determine the spatial distribution of abundance before other processes occur. For each population season, migration and emigration rates are arranged into a matrix $\mathbf{D}_{\text {season }}^{\text {mig }}$, a block diagonal matrix : 
Accepted for publication in Fish and Fisheries

$$
\mathbf{D}_{\text {season }}^{\text {mig }}=\left[\begin{array}{ccccc}
D_{11} & \cdots & D_{i 1} & \cdots & D_{n 1} \\
\vdots & \ddots & \vdots & \ddots & \vdots \\
D_{1 j} & \cdots & D_{i j} & \cdots & D_{n j} \\
\vdots & \ddots & \vdots & \ddots & \vdots \\
D_{1 n} & \cdots & D_{i n} & \cdots & D_{n n}
\end{array}\right],
$$

where $\boldsymbol{D}_{\boldsymbol{i j}}$ is a diagonal matrix of dimension NbClass of $c^{\text {th }}$ diagonal element :

$$
d_{i j}(c)=\left\{\begin{array}{c}
m_{i j}(c) \text { if } i \neq j \\
1-\sum_{i \neq j} m_{i j}(c)-e_{i}(c) \text { if } i=j
\end{array}\right.
$$

where $e_{i}(c)$ is the emigration coefficient from class $c$ outside population zone $i$, and $m_{i j}(c)$ is the migration rate of class $c$ from population zone $j$ to population zone $i$ at the beginning of the season. Note that $d_{i i}(c)$ corresponds to the proportion of fish of class $c$ staying in zone $i$.

Possible immigration is modelled through $\mathbf{N}_{\text {season }}^{\text {immig }}$, a vector structured like $\mathrm{N}(\mathrm{t})$ (equ. (1)), denoting the number of fish per class immigrating into the region at the beginning of the season.

Reproduction and recruitment were considered separately because for many fish populations, they take place in distinct zones and at different times of the year (see e.g. Rowley 1994). The model accommodates several reproduction zones (spawning areas) and several recruitment zones per population. Reproduction (resp. recruitment) occurs independently in each reproduction (resp. recruitment) zone. Correspondence between reproduction and recruitment zones may be specified. If several recruitment zones are associated to a reproduction zone, births are distributed uniformly among recruitment zones. Reproduction occurs at each month of the reproduction season delimited by starting and ending months, $t_{\text {repro }}^{\text {inf }}$ and $t_{\text {repro }}^{\text {sup }}$. Reproduction outcome may depend on the parental stock or it may be constant. The relationship between spawner abundance and reproduction outcome may be chosen among known relationships like Ricker, Beverton-Holt models, or alternatively another relationship may be written. The number of births at time $t$ in reproduction zone $z$ is :

$$
N_{\text {birth }}(t, z)=p_{\text {repro }}(t) f_{s r}\left(N_{s p}(t, z)\right) \text {, }
$$


Accepted for publication in Fish and Fisheries

where $f_{s r}$ represents the relationship between spawner abundance and reproduction outcome, which may depend on additional parameters, and $N_{s p}(t, z)$ is the number of mature animals in $z$ at $t . p_{\text {repro }}(t)$ is the proportion of mature individuals ready for reproduction at time $t$, and accounts for the temporal spread of reproduction over the reproduction season.

After birth, newborns are subject to natural mortality until recruitment. For a monthly cohort of births, recruitment duration is determined by the minimum time $\Delta_{\text {rec }}$ and the maximum time required by a newborn to recruit denoted $\Delta_{\text {rec }}+\tau_{\text {rec }}$. The corresponding time interval may be seen as resulting from individual variation in development. Recruitment season is hence determined by both recruitment duration for a cohort, and by the length of the reproduction season, i.e. it starts at month $t_{\text {repro }}^{\mathrm{inf}}+\Delta_{\text {rec }}$, and finishes at month $t_{\text {repro }}^{\text {sup }}+\Delta_{\text {rec }}+\tau_{\text {rec }}$.

Under these assumptions, the number of fish recruiting in recruitment zone $z_{\text {rec }}$ at a given month of the recruitment season is :

$$
N_{\text {rec }}\left(t, z_{\text {rec }}\right)=\frac{1}{n_{\text {zrec }}} \sum_{i=1}^{\tau_{\text {rec }}} p_{\text {rec }}(i) N_{\text {birth }}\left(t-\Delta-i-t_{\text {repro }}^{\mathrm{inf}}+1, z_{\text {repro }}\right) \exp \left(-M_{\text {birth }}(\Delta+i-1)\right),
$$

where $p_{\text {rec }}(i)$ denotes the proportion of a cohort that recruits at the $i^{\text {th }}$ time (recall that a cohort recruits during $\tau_{\text {rec }}$ months); thereby accounting for the temporal distribution of recruitment over recruitment season. $n_{\text {zrec }}$ is the number of recruitment zones associated to $Z_{\text {repro, }}$, and $M_{\text {birth }}$ is the natural mortality rate of new borns (in months ${ }^{-1}$ ) until they recruit. $N_{\text {rec }}\left(t, z_{\text {rec }}\right)$ is arranged into a recruitment vector $\mathrm{R}(\mathrm{t})$. 


\section{Appendix 2 : Modelling spatial and seasonal variations in catchability}

This appendix describes the way spatial and seasonal variations in catchability were modelled in ISISFish, so that concentration effects are consistent between classes, and between zones and seasons.

Due to concentration effects, a population class present in several zones at month $t$ has a higher catchability in the smallest of these zones. Assuming that catchability is uniform across cells within a zone, we get:

$$
q_{p o p}\left(c, z_{i}, t\right)=q_{p o p}\left(c, z_{j}, t\right) \frac{\operatorname{NbCells}\left(z_{j}\right)}{\operatorname{NbCells}\left(z_{i}\right)}
$$

where $z_{i}$ and $z_{j}$ are two populations zones of class $c$ at $t$, and NbCells $(z)$ is the number of cells in zone $z$.

This concentration effect may be understood by considering fishing effort in terms of area fished by the gear, e.g. swept area in the case of a trawl. This area is assumed to be constant per unit effort. If we denote $\operatorname{Pr}(c$ in Area $\mid c$ in $z)$ the probability that a fish present in zone $z$ is in this area, the catchability of population class $c$ at $t$ in zone $z$ may be written in probabilistic terms :

$$
q_{\text {pop }}(c, z, t)=\operatorname{Pr}(\text { c catchable at } t \mid c \text { in } z)=\operatorname{Pr}(\text { c catchable at } t \mid c \text { in Area }) \operatorname{Pr}(c \text { in Area } \mid c \text { in } z)
$$

$\operatorname{Pr}(\mathrm{c}$ in Area $\mid c$ in $z)$ may be written as a function of the relative surfaces of Area and $z$ :

$$
\operatorname{Pr}(c \text { in Area } \mid c \text { in } z)=\frac{\operatorname{Surface}(\text { Area })}{N b \operatorname{Cells}(\mathrm{z})},
$$

Surface(Area) being expressed in number of cells. Note that $\operatorname{Pr}(c$ in Area $\mid c$ in $z)$ is independent of populations and seasons. It is not the probability that the fish be caught by the gear, since selectivity is not taken into account at this stage. Surface(Area) is a scale parameter that is confounded with the gear standardization factor.

Equ. (A2.2) amounts to separate spatial and seasonal effects of catchability, namely :

$$
q_{\text {pop }}(c, z, t)=\underbrace{\bar{q}_{\text {pop }}(c, t)}_{\text {seasonal }} \underbrace{\operatorname{Pr}(c \text { in Area } \mid c \text { in } z)}_{\text {spatial }},
$$


Accepted for publication in Fish and Fisheries

where the average catchability $\bar{q}_{p o p}(c, t)$ accounts for possible behavioural effects, and the second term accounts for concentration effects.

Under the previous condition, two classes from the same population or from distinct populations present in $z$ at $t$ have same catchability, independently of class-specific behavioural effects, and catchability of a given class in a given zone only varies through seasonal effects. 


\section{Tables}

Table 1. Model assumptions for non spatial and metapopulation models. References in italics are bioeconomic models quoted in subsection 2.2. Movement assumptions were considered as implicit when models were not spatially-explicit. When an assumption was specific to a reference, the latter was reported between parentheses.

\begin{tabular}{|c|c|c|c|}
\hline References & $\begin{array}{l}\text { Spatially- } \\
\text { explicit } \\
(\mathrm{Y} / \mathrm{N})\end{array}$ & Movement assumptions (implicit or explicit) & Model type / Main assumptions \\
\hline $\begin{array}{l}\text { Lauck et al. 1998; Parrish 1999; Hastings } \\
\text { and Botsford 1999; Dahlgren and Sobel } \\
\text { 2000; Mangel 1998, 2000a a }, 2000 c ; \\
\text { Pezzey et al. 2000; Acosta } 2002\end{array}$ & $\mathrm{~N}$ & $\begin{array}{l}\text { Instantaneous dispersion of fish over the whole area, (uniform } \\
\text { distribution) }\end{array}$ & $\begin{array}{l}\text { Logistic growth or Ricker stock-recruitment } \\
\text { Stochastic exploitation rate (Lauck et al . } 1998 \text {; } \\
\text { Mangel 2000a) }\end{array}$ \\
\hline Horwood et al. 1998 & $\mathrm{~N}$ & Idem & $\begin{array}{l}\text { Age-structured yield per recruit (Beverton and } \\
\text { Holt 1957) }\end{array}$ \\
\hline Botsford et al. 1993 & $\mathrm{~N}$ & Sedentary species & Length-structured yield per recruit \\
\hline Man et al. 1995 & $\mathrm{Y}$ & Random dispersion of fish between patches & Patch occupancy model (Levins 1970) \\
\hline $\begin{array}{l}\text { Crowder et al. } 2000 \text {; Sanchirico and Wilen } \\
\text { 2001a and b; Anderson } 2002 \text {; Hannesson } \\
\text { 1998, } 2002 \text {; Rodwell et al. } 2002\end{array}$ & $\mathrm{Y}$ & $\begin{array}{l}\text { Dispersion between source and sink patches (Crowder et al. 2000) } \\
\text { Several dispersal schemes : closed subpopulations, a two-patch } \\
\text { source-sink system, and density-dependent dispersal between } \\
\text { patches (Sanchirico and Wilen 2001b) }\end{array}$ & $\begin{array}{l}\text { Source-sink model } \\
\text { Logistic growth }\end{array}$ \\
\hline
\end{tabular}


Accepted for publication in Fish and Fisheries

\begin{tabular}{|c|c|c|c|}
\hline $\begin{array}{l}\text { Tuck and Possingham 1994, } 2000 \\
\text { Supriatna and Possingham } 1998\end{array}$ & $\mathrm{Y}$ & Larval pool & $\begin{array}{l}\text { Metapopulation model } \\
\text { Logistic growth } \\
\text { Predator-prey relationships (Supriatna and } \\
\text { Possingham 1998) }\end{array}$ \\
\hline Brown and Roughgarden 1997 & $\mathrm{Y}$ & $\begin{array}{l}\text { Larval pool } \\
\text { Sedentary adults distributed in many patches and competing for } \\
\text { space }\end{array}$ & Metapopulation model \\
\hline $\begin{array}{l}\text { Quinn et al. } 1993 \text {; Hastings and Botsford } \\
2003\end{array}$ & $\mathrm{Y}$ & $\begin{array}{l}\text { One-dimensional model } \\
\text { Larval pool } \\
\text { Four stages (Quinn et al. 1993) }\end{array}$ & $\begin{array}{l}\text { Reproduction only in reserves } \\
\text { Local survival rate } \\
\text { Allee effect (Quinn et al. 1993) }\end{array}$ \\
\hline
\end{tabular}

\footnotetext{
${ }^{\mathrm{a}}$ This paper also considers additional mortality due to habitat destruction
} 
Accepted for publication in Fish and Fisheries

Table 2. Management scenarios considered in non spatial and metapopulation models. No-take zone corresponds to permanent total prohibition of fishing in a zone. F and MSY

respectively stand for fishing mortality and Maximum Sustainable Yield.

\begin{tabular}{|c|c|c|c|c|}
\hline References & $\begin{array}{l}\text { MPA-related } \\
\text { scenario }\end{array}$ & $\begin{array}{l}\text { MPA-related } \\
\text { parameter }\end{array}$ & $\begin{array}{l}\text { Other policy } \\
\text { options }\end{array}$ & Main results for MPA design and for comparison of policies \\
\hline $\begin{array}{l}\text { Lauck et al. } 1998 \\
\text { Dahlgren and Sobel } \\
2000\end{array}$ & $\begin{array}{l}\text { no-take zone } \\
\text { size }\end{array}$ & $\begin{array}{l}\text { \% of biomass } \\
\text { available to fishing }\end{array}$ & $\begin{array}{ll}\text { no } \\
\end{array}$ & $\begin{array}{l}\text { Risk of population collapse increases a lot when reserve size decreases (Lauck et al. 1998) } \\
30-40 \% \text { reserve size required (Dahlgren and Sobel 2000) }\end{array}$ \\
\hline $\begin{array}{l}\text { Parrish } 1999 \\
\text { Pezzey et al. } 2000\end{array}$ & $\begin{array}{l}\text { no-take zone } \\
\text { size }\end{array}$ & $\begin{array}{l}\% \text { of fishing grounds } \\
\text { closed to fishing }\end{array}$ & $\begin{array}{l}\text { overall } \\
\text { exploitation } \\
\text { rate (Parrish } \\
\text { 1999) }\end{array}$ & $\begin{array}{l}\text { Large reserves may have detrimental effects due to effort increase in open areas (Parrish 1999) } \\
20-40 \% \text { reserve size required to maximize catch (Pezzey et al. 2000) }\end{array}$ \\
\hline $\begin{array}{l}\text { Mangel 1998,2000a, } \\
\text { 2000c } \\
\text { Hastings and Botsford } \\
1999\end{array}$ & $\begin{array}{l}\text { no-take zone } \\
\text { size }\end{array}$ & $\begin{array}{l}\% \text { of fishing grounds } \\
\text { closed to fishing }\end{array}$ & $\begin{array}{l}\text { overall } \\
\text { exploitation } \\
\text { rate }\end{array}$ & $\begin{array}{l}20 \text { to } 30 \% \text { reserve size required to warrant population persistence (Mangel 2000a) } \\
\text { Catch larger than without reserve (Mangel 2000a) } \\
\text { MSY reached for an infinity of combinations of exploitation rates and reserve size (Mangel 1998) } \\
\text { Equivalence in yield between reserve and harvest rate regulation (Hastings and Botsford 1999) }\end{array}$ \\
\hline Acosta 2002 & $\begin{array}{l}\text { no-take zone } \\
\text { size and shape }\end{array}$ & $\%$ of region closed & no & $\begin{array}{l}\text { A more compact reserve would not change much from the actual design } \\
\text { A } 50 \% \text { increase in reserve size would substantially increase population size }\end{array}$ \\
\hline Quinn et al. 1993 & $\begin{array}{l}\text { no-take zone } \\
\text { spacing }\end{array}$ & $\begin{array}{l}\text { zero F in closed } \\
\text { patches }\end{array}$ & $\begin{array}{l}\text { overall } \\
\text { exploitation } \\
\text { rate }\end{array}$ & $\begin{array}{l}\text { Population crashes if no refugia } \\
\text { Every other patch or every third patch closed required for population persistence under reasonable } \\
\text { fishing intensity }\end{array}$ \\
\hline
\end{tabular}


Accepted for publication in Fish and Fisheries

\begin{tabular}{|c|c|c|c|c|}
\hline $\begin{array}{l}\text { Hastings and Botsford } \\
2003\end{array}$ & $\begin{array}{l}\text { no-take zone } \\
\text { size and number }\end{array}$ & $\begin{array}{l}\% \text { of area closed } \\
\text { no-take zone width }\end{array}$ & no & Conservation and maximum fisheries yield attained for distinct reserve designs. \\
\hline Horwood et al. 1998 & $\begin{array}{l}\text { seasonal closure of } \\
\text { spawning ground to } \\
\text { trawling }\end{array}$ & $\begin{array}{l}\% \text { of fishing } \\
\text { mortality }\end{array}$ & & Closure has no positive effect if effort reallocated outside closed area \\
\hline Botsford et al. 1993 & rotating closures & $\begin{array}{l}\% \text { of protected } \\
\text { biomass }\end{array}$ & $\begin{array}{l}\text { overall } \\
\text { exploitation } \\
\text { rate }\end{array}$ & Not detailed \\
\hline $\begin{array}{l}\text { Crowder et al. } 2000 \\
\text { Sanchirico and Wilen } \\
2001 b \\
\text { Tuck and Possingham } \\
1994,2000 \\
\text { Supriatna and } \\
\text { Possingham } 1998\end{array}$ & $\begin{array}{l}\text { no-take zone } \\
\text { location and three } \\
\text { sizes }(5 \%, \quad 10 \% \text {, } \\
20 \%)(\text { Crowder et } \\
\text { al. 2000) }\end{array}$ & $\begin{array}{l}\text { zero F in closed } \\
\text { patches }\end{array}$ & $\begin{array}{l}\text { exploitation } \\
\text { rate in open } \\
\text { patches }\end{array}$ & $\begin{array}{l}20 \% \text { reserve size required if fishing is high. Reserve must be established in source patch } \\
\text { Negative effects if established in sink patch and high exploitation rate } \\
\text { If oriented density-dependent dispersal, reserve in sink will increase total biomass and decrease } \\
\text { total catch } \\
\text { If oriented dispersal, reserve in source will increase total biomass. Total catch will increase only } \\
\text { under certain biological (high intrinsic growth rates and intermediate dispersal rates) and } \\
\text { economic conditions (see Table 6) }\end{array}$ \\
\hline $\begin{array}{l}\text { Brown and } \\
\text { Roughgarden } 1997\end{array}$ & $\begin{array}{l}\text { no-take zone } \\
\text { reserve location }\end{array}$ & $\begin{array}{l}\text { zero } F \text { in closed } \\
\text { patch }\end{array}$ & & $\begin{array}{l}\text { Maximum economic rent when only one subpopulation is exploited and the others are kept as } \\
\text { spawning stock. }\end{array}$ \\
\hline $\begin{array}{l}\text { Hastings and Botsford } \\
2003\end{array}$ & $\begin{array}{l}\text { no-take zone } \\
\text { number overall size }\end{array}$ & & & $\begin{array}{l}\text { Conservation of resource and maximization of fisheries yields are attained for different designs in } \\
\text { terms of overall size of reserve network and reserve number }\end{array}$ \\
\hline
\end{tabular}




\section{Accepted for publication in Fish and Fisheries}

Table 3. Model assumptions for spatially-explicit demographic models. References in italics are bioeconomic models mostly quoted in subsection 2.2. yr, mo, wk and d respectively stand for year, month, week and day.

\begin{tabular}{|c|c|c|c|}
\hline References & Spatial assumptions & Model type / Main assumptions & $\begin{array}{l}\text { Time } \\
\text { step }\end{array}$ \\
\hline Gendron and Brêthes 2002 & $\begin{array}{l}\text { Population distributed in two patches linked by non-oriented } \\
\text { exchanges of recruited groups. }\end{array}$ & $\begin{array}{l}\text { Equilibrium yield per recruit model (constant exploitation rate, } \\
\text { constant recruitment) } \\
\text { Intrannual dynamics of a cohort }\end{array}$ & $\mathrm{d}$ \\
\hline $\begin{array}{l}\text { Beverton and Holt 1957; } \\
\text { Polacheck 1990; DeMartini } \\
\text { 1993; Sumaila 1998, } 2002\end{array}$ & $\begin{array}{l}\text { Population distributed in two patches linked by non-oriented } \\
\text { exchanges of recruited groups. }\end{array}$ & Equilibrium age-structured yield per recruit & $\mathrm{yr}$ \\
\hline $\begin{array}{l}\text { Die and Watson } 1992 \\
\text { Christensen and Lassen } 1996\end{array}$ & One-way oriented migrations & Equilibrium age-structured yield per recruit & $\mathrm{yr}$ \\
\hline Maury and Gascuel 1999 & $\begin{array}{l}\text { Advection-diffusion } \\
\text { Environmental heterogeneity }\end{array}$ & Equilibrium age-structured yield per recruit & $5 d$ \\
\hline Attwood and Bennett 1995 & $\begin{array}{l}\text { One-dimensional model (linear coastline) } \\
\text { Non-oriented dispersal of larvae and juveniles } \\
\text { Three species with distinct dispersal schemes }\end{array}$ & $\begin{array}{l}\text { Age-structured } \\
\text { Beverton-Holt stock-recruitment }\end{array}$ & $\mathrm{yr}$ \\
\hline Holland and Brazee 1996 & Larval pool & Age-structured & $\mathrm{yr}$ \\
\hline
\end{tabular}


Accepted for publication in Fish and Fisheries

\begin{tabular}{|c|c|c|c|}
\hline & Density-dependent migration between patches & Ricker stock-recruitment & \\
\hline Lundberg and Jonzen 1999 & $\begin{array}{l}\text { Ideal Free Distribution (IFD)(Fretwell and Lucas 1970) } \\
\text { Habitat heterogeneity }\end{array}$ & $\begin{array}{l}\text { Two-stage structured } \\
\text { Ricker and Beverton-Holt stock-recruitment }\end{array}$ & $\mathrm{yr}$ \\
\hline $\begin{array}{l}\text { Sladek Nowlis and Roberts } \\
\text { 1999; Sladek Nowlis } 2000\end{array}$ & $\begin{array}{l}\text { Larval pool } \\
\text { Sedentary adults }\end{array}$ & $\begin{array}{l}\text { Length-structured } \\
\text { Constant length-dependent fecundity rates } \\
\text { Density-dependent survival of juveniles }\end{array}$ & $\mathrm{yr}$ \\
\hline St Mary et al. 2000 & Juveniles and adults are sedentary and spatially segregated & $\begin{array}{l}\text { Two-stage structured } \\
\text { Beverton-Holt stock-recruitment } \\
\text { Density-dependent maturation rates }\end{array}$ & $\mathrm{yr}$ \\
\hline Morgan and Botsford 2001 & $\begin{array}{l}\text { One-dimensional (linear coastline) } \\
\text { Four dispersal schemes for larvae : single source, limited } \\
\text { distance, larval pool, headlands } \\
\text { Sedentary adults }\end{array}$ & $\begin{array}{l}\text { Length-structured based on Von Bertalanffy growth } \\
\text { Beverton-Holt dependence between larvae and settlement }\end{array}$ & $\mathrm{yr}$ \\
\hline
\end{tabular}


Accepted for publication in Fish and Fisheries

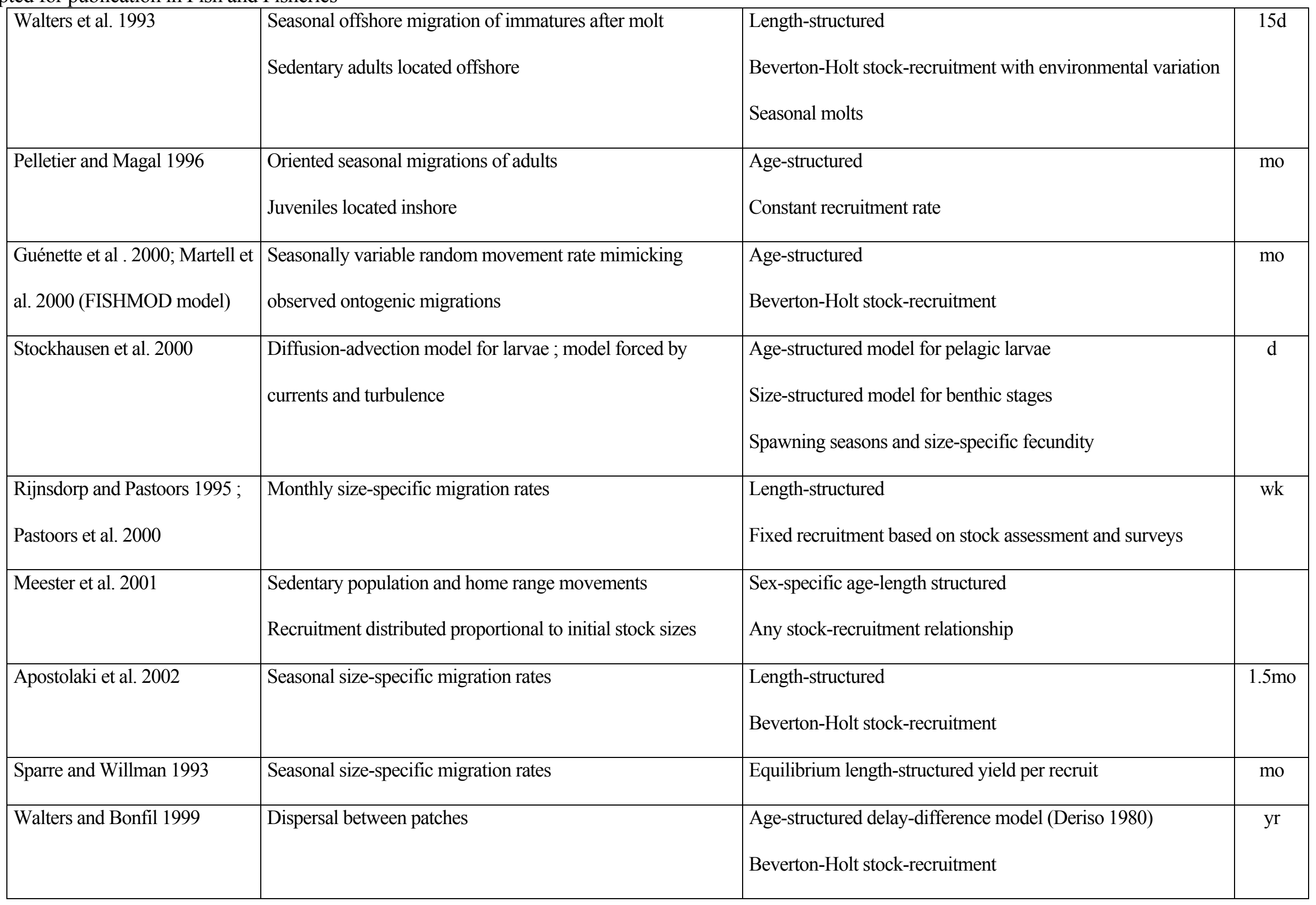


Accepted for publication in Fish and Fisheries

\begin{tabular}{|l|l|l|}
\hline Holland 2000 & $\begin{array}{l}\text { Seasonal oriented migrations and permanent dispersion } \\
\text { Recruitment distribution uniform over the region }\end{array}$ & Age-structured \\
\hline Holland 2002 & $\begin{array}{l}\text { One-dimensional model } \\
\text { Advection-diffusion movement } \\
\text { Recruiment distribution Gaussian from grid center }\end{array}$ & $\begin{array}{l}\text { Age-structured } \\
\text { Beverton-Holt stock-recruitment }\end{array}$ \\
\end{tabular}


Accepted for publication in Fish and Fisheries

Table 4. Management scenarios considered in spatially-explicit demographic models. No-take zone corresponds to permanent total prohibition of fishing in a zone. SSB stands for

Spawning Stock Biomass.

\begin{tabular}{|c|c|c|c|c|}
\hline References & MPA-related scenario & $\begin{array}{l}\text { MPA-related } \\
\text { parameter }\end{array}$ & Other policy options & Main results for MPA design and for comparison of policies \\
\hline $\begin{array}{l}\text { Gendron and } \\
\text { Brêthes } 2002\end{array}$ & $\begin{array}{l}\text { opening and closure } \\
\text { of the fishery }\end{array}$ & $\begin{array}{l}\text { timing of opening } \\
\text { and closure of } \\
\text { fishery }\end{array}$ & overall fishing effort & $\begin{array}{l}\text { Spatial closure more efficient than temporal closure for decreasing exploitation rate } \\
\text { Delayed opening of the fishing season is more efficient than earlier closure of fishing season } \\
\text { Reduction of } 20 \% \text { in overall effort is equivalent to a delayed opening of one week in terms of } \\
\text { exploitation rate }\end{array}$ \\
\hline $\begin{array}{l}\text { Beverton and } \\
\text { Holt } 1957 ; \\
\text { Polacheck } 1990 \\
\text { DeMartini } 1993 ; \\
\text { Die and Watson } \\
1992 ; \\
\text { Christensen and } \\
\text { Lassen } 1996\end{array}$ & no-take zone & $\begin{array}{l}\% \text { of cohort } \\
\text { initially in no-take } \\
\text { zone }\end{array}$ & $\begin{array}{l}\text { overall exploitation } \\
\text { rate }\end{array}$ & $\begin{array}{l}\text { Reserve leads to increased yield per recruit and additional spawning biomasses only when fishing } \\
\text { mortality is high (Polacheck } 1990 \text {; DeMartini 1993) } \\
\text { Moderate gain in yield, because fishing effort reallocated to the open patch } \\
\text { Substantial increase in spawning biomass, even for small reserve sizes (Polacheck 1990 ; DeMartini } \\
\text { 1993). } \\
\text { Reserve may lead to decreased yield per recruit (Die and Watson 1992) } \\
\text { Gain in yield increases with reserve size, but decreases with population mobility (Beverton and Holt } \\
\text { 1957; Polacheck 1990) }\end{array}$ \\
\hline $\begin{array}{l}\text { Maury and } \\
\text { Gascuel } 1999\end{array}$ & no-take zone size & $\%$ of region closed & no & $\begin{array}{l}\text { Yield maximized through no-take zone, except for resident species } \\
\text { Optimum reserve size ranges from } 20 \% \text { (weakly diffusive species) to } 80 \% \text { (highly diffusive } \\
\text { species) }\end{array}$ \\
\hline
\end{tabular}


Accepted for publication in Fish and Fisheries

\begin{tabular}{|c|c|c|c|c|}
\hline $\begin{array}{l}\text { Walters et al. } \\
1993\end{array}$ & $\begin{array}{l}\text { Spatial and seasonal } \\
\text { closures } \\
\text { Effort limit per area }\end{array}$ & patches closed & $\begin{array}{l}\text { Minimal size limit, } \\
\text { licenses, } \\
\text { gear number, effort } \\
\text { per } 15 \text { days }\end{array}$ & $\begin{array}{l}\text { Whatever the policy, it is difficult to reduce immature exploitation without catch loss } \\
\text { Size limit controls, late opening and seasonal closure increase spawning stock by } 25-30 \% \text {, but decrease } \\
\text { catch by } 15 \%\end{array}$ \\
\hline $\begin{array}{l}\text { Attwood and } \\
\text { Bennett } 1995\end{array}$ & $\begin{array}{l}\text { no-take zone } \\
\text { size and spacing }\end{array}$ & $\begin{array}{l}\% \text { of region closed } \\
\text { Distance between } \\
\text { no-take zone }\end{array}$ & & $\begin{array}{l}\text { When recruitment is constant, yield cannot be increased through a reserve } \\
\text { In the case of stock-recruitment dependence, yield may increase from more than } 50 \% \\
\text { For mobile species, only total reserve size matters, and yield increases through reserve } \\
\text { For sedentary populations with larval dispersal, several regularly spaced small reserves are more } \\
\text { desirable to facilitate larval transport }\end{array}$ \\
\hline $\begin{array}{l}\text { Holland and } \\
\text { Brazee } 1996\end{array}$ & $\begin{array}{l}\text { no-take zone } \\
\text { size }\end{array}$ & $\%$ of region closed & overall fishing effort & $\begin{array}{l}\text { When fishing effort high, present value of harvest maximized with reserve size of } 15-19 \% \\
\text { If effort is low or can be reduced, reserves provide little or negative benefits }\end{array}$ \\
\hline $\begin{array}{l}\text { Guénette and } \\
\text { Pitcher } 1999\end{array}$ & no-take zone size & $\%$ of region closed & $\begin{array}{l}\text { overall exploitation } \\
\text { rate }\end{array}$ & $\begin{array}{l}\text { No-take zone sizes }>30 \% \text { increase spawner and recruitment levels, even at high exploitation rates } \\
\text { Exploitation rate must be reduced to increase yield } \\
\text { High transfer rates decrease the benefit of no-take zones }\end{array}$ \\
\hline $\begin{array}{l}\text { Pelletier and } \\
\text { Magal } 1996\end{array}$ & $\begin{array}{l}\text { spatial and seasonal } \\
\text { allocation of fishing } \\
\text { effort }\end{array}$ & $\begin{array}{l}\% \text { inshore fleet's } \\
\text { effort, \% industrial } \\
\text { fleet's effort }\end{array}$ & overall fishing effort & $\begin{array}{l}\text { Catch and biomass maximized by closing spawning grounds during reproduction } \\
\text { No short-term loss of catch incurred under corresponding effort allocation } \\
\text { Optimal closure for stock is equivalent to a } 95 \% \text { reduction in overall fishing effort } \\
72 \% \text { reduction in overall effort needed to cease overexploitation }\end{array}$ \\
\hline Lundberg and & no-take zone size & $\%$ of region closed & harvest rate outside & Catch outside reserve are greatly enhanced by habitat quality in the reserve \\
\hline
\end{tabular}


Accepted for publication in Fish and Fisheries

\begin{tabular}{|c|c|c|c|c|}
\hline Jonzen 1999 & & & reserve & With density-dependent habitat selection, reserve must be larger to be efficient \\
\hline $\begin{array}{l}\text { Sladek Nowlis } \\
\text { and Roberts } 1999\end{array}$ & no-take zone size & $\%$ of region closed & $\begin{array}{l}\text { overall fishing } \\
\text { mortality }\end{array}$ & $\begin{array}{l}40 \% \text { reserve size required to sustain fishery by larval dispersal } \\
75-80 \% \text { reserve size require to maximize long-term yield for two species } \\
\text { Catch variability decreases with reserve size }\end{array}$ \\
\hline $\begin{array}{l}\text { Sladek Nowlis } \\
2000\end{array}$ & $\begin{array}{l}\text { no-take zone } \\
\text { temporary closure of } \\
\text { the fishery }\end{array}$ & $\%$ of region closed & minimum size limit & $\begin{array}{l}\text { 10-40\% no-take zone performs like } 10-40 \% \text { size limit (i.e. } 10-40 \% \text { of the smallest catch escapement) } \\
\text { For all policies, initial drop in catch and subsequent increase above status quo levels } \\
\text { Moderate gain in yield for reserve sizes beyond } 20 \%\end{array}$ \\
\hline $\begin{array}{l}\text { St Mary et al. } \\
2000\end{array}$ & $\begin{array}{l}\text { no-take zone size and } \\
\text { number }\end{array}$ & $\begin{array}{l}\% \text { of habitat } \\
\text { closed } \\
\text { spacing }\end{array}$ & no & $\begin{array}{l}\text { Optimal reserve design depends on management objective (conservation or yield maximisation): } \\
\text { increasing the fishable stock decreases total adult stock. } \\
\text { Closing juvenile habitat is the best option to maximize fishable stock }\end{array}$ \\
\hline Mangel 2000b & no-take zone size & $\%$ habitat closed & $\begin{array}{l}\text { overall exploitation } \\
\text { rate }\end{array}$ & $\begin{array}{l}\text { Smaller reserves lead to larger but more variable catch } \\
40 \% \text { reserve size optimal for catch discounted by variance }\end{array}$ \\
\hline Martell et al. 2000 & $\begin{array}{l}\text { seasonal and spatial } \\
\text { closures }\end{array}$ & $\begin{array}{l}\text { zero effort in } \\
\text { closed area/season }\end{array}$ & minimum size limit & $\begin{array}{l}\text { Yield maximum when effort is cut by half through a 2-months opening } \\
\text { Effort best reduced through a } 10 \% \text { no-take zone } \\
\text { Larger MPA, longer openings and size limits lead to lower yields and higher exploitation rates }\end{array}$ \\
\hline $\begin{array}{l}\text { Guénette et al. } \\
2000\end{array}$ & $\begin{array}{l}\text { no-take zone size and } \\
\text { location, seasonal } \\
\text { closures per fleet }\end{array}$ & $\begin{array}{l}\text { zero effort in } \\
\text { closed area/season }\end{array}$ & & $\begin{array}{l}\text { No-take zones below } 40 \% \text { did not prevent collapse, } 80 \% \text { no-take zone allows rebuilding } \\
\text { Seasonal closures do not stop stock decline } \\
20 \% \text { no-take zone }+ \text { seasonal closure allow rebuilding but catch remain low }\end{array}$ \\
\hline Stockhausen et al. & no-take zone & $\%$ of coastline & no & Reserve location matters as much as reserve size \\
\hline
\end{tabular}


Accepted for publication in Fish and Fisheries

\begin{tabular}{|c|c|c|c|c|}
\hline 2000 & size and location & & & $\begin{array}{l}\text { Reserve performance strongly depends on hydrodynamic scenario, but largest increases in catch } \\
\text { obtained for reserve sizes between } 5 \text { and } 25 \%\end{array}$ \\
\hline $\begin{array}{l}\text { Morgan and } \\
\text { Botsford } 2001\end{array}$ & $\begin{array}{l}\text { no-take zone size and } \\
\text { location }\end{array}$ & $\begin{array}{l}\text { fraction of area } \\
\text { protected }\end{array}$ & $\begin{array}{l}\text { overall exploitation } \\
\text { rate }\end{array}$ & $\begin{array}{l}\text { Reserve efficiency strongly depends on dispersal scheme } \\
\text { A } 4 \% \text { reserve size led to substantial catch increase and a reduction in catch variability if initial } \\
\text { recruitment overfishing }\end{array}$ \\
\hline $\begin{array}{l}\text { Pastoors et al. } \\
2000\end{array}$ & $\begin{array}{l}\text { seasonal closure per } \\
\text { fleet, timing of } \\
\text { closure }\end{array}$ & $\begin{array}{l}\text { zero fishing effort } \\
\text { in closed area }\end{array}$ & no & $\begin{array}{l}\text { All considered closures reduce discards and enhance landings and SSB } \\
\text { Longer closures and closure for all fleets are beneficial to the stock } \\
\text { A permanent no-take zone yields the highest landings per recruit and SSB }\end{array}$ \\
\hline $\begin{array}{l}\text { Meester et al. } \\
2001\end{array}$ & $\begin{array}{l}\text { no-take zone size and } \\
\text { number, partial } \\
\text { protection }\end{array}$ & $\%$ stock protected & $\begin{array}{l}\text { overall reduction of } \\
\text { recreational fishing }\end{array}$ & $\begin{array}{l}\text { A zoning plan with } 5 \text { reserves requires less total area to protect the same number of fish } \\
\text { Best protection of fish stocks achieved by closing the whole park to fishing } \\
\text { Partial closures of the park are beneficial to different species groups depending on location }\end{array}$ \\
\hline $\begin{array}{l}\text { Apostolaki et al. } \\
2002\end{array}$ & no-take zone location & $\begin{array}{l}\text { zero fishing effort } \\
\text { in closed area }\end{array}$ & $\begin{array}{l}\text { effort constant in } \\
\text { open area } \\
\text { gear selectivity }\end{array}$ & $\begin{array}{l}\text { Closing nursery is always beneficial to the fishery } \\
\text { Closing spawning area is beneficial if fishing mortality is high } \\
\text { Greatest benefits when targetted size classes are protected } \\
\text { Effort reduction provides less benefits than no-take zone }\end{array}$ \\
\hline $\begin{array}{l}\text { Sparre and } \\
\text { Willman } 1993\end{array}$ & $\begin{array}{l}\text { spatial / seasonal } \\
\text { allocation of effort per } \\
\text { fleet }\end{array}$ & $\begin{array}{l}\text { fishing effort per } \\
\text { area }\end{array}$ & $\begin{array}{l}\text { licenses } \\
\text { taxes } \\
\text { fleet selectivity }\end{array}$ & $\begin{array}{l}\text { Calculates equilibrium projection from initial allocation of fishing effort } \\
\text { Generic model } \\
\text { No results presented }\end{array}$ \\
\hline Walters and & no-take zone & & overall fishing effort & Spatial reallocation of fishing effort drastically changes consequences of policies \\
\hline
\end{tabular}


Accepted for publication in Fish and Fisheries

\begin{tabular}{|c|c|c|c|c|}
\hline Bonfil 1999 & $\begin{array}{l}\text { temporary closure } \\
\text { TAC per area }\end{array}$ & & & $\begin{array}{l}\text { TAC per species and fishing grounds appropriate to sustain the resources provided accurate annual stock } \\
\text { assessments } \\
\text { Desirable policy includes limiting overall effort, few no-take zones protecting key areas for biodiversity } \\
\text { or to reduce discards, and temporary closures in case of local depletions of fish aggregations }\end{array}$ \\
\hline Holland 2000 & $\begin{array}{l}\text { no-take zone size and } \\
\text { location }\end{array}$ & $\begin{array}{l}\text { zero effort in } \\
\text { closed area }\end{array}$ & overall fishing effort & $\begin{array}{l}\text { Closures in areas where fish aggregate seasonally result in sharp reductions in fishing mortality even if } \\
\text { total effort remains constant } \\
\text { Reserves useful to increase equilibrium harvest and SSB for overexploited stocks, but not to increase the } \\
\text { value of the fishery }\end{array}$ \\
\hline Holland 2002 & $\begin{array}{l}\text { no-take zone size and } \\
\text { location }\end{array}$ & & $\begin{array}{l}\text { tax on revenue } \\
\text { mesh size }\end{array}$ & $\begin{array}{l}\text { In single species context, highest net revenue with a large mesh size and a 10\% closure on nursery } \\
\text { grounds, and closures directed at older ages are not desirable } \\
\text { In a multispecies context, highest revenues correspond to low effort and slight increase in mesh size. Use } \\
\text { of closures or taxes provides little gain }\end{array}$ \\
\hline
\end{tabular}


Accepted for publication in Fish and Fisheries

Table 5. Model features, management scenarios considered and main results for ecosystem models. AR and EEZ respectively stand for Artificial Reef and Exclusive Economic Zone.

\begin{tabular}{|c|c|c|c|}
\hline References & MPA-related scenario & $\begin{array}{l}\text { Other policies } \\
\text { considered }\end{array}$ & Main results for MPA design and for comparison of policies \\
\hline $\begin{array}{l}\text { McClanahan } \\
1995\end{array}$ & $\begin{array}{l}\text { consider protected and } \\
\text { unprotected areas in } \\
\text { examples }\end{array}$ & $\begin{array}{l}\text { fishing } \\
\text { intensity } \\
\text { catch selection }\end{array}$ & $\begin{array}{l}\text { Fishing all groups results in reef dominance by sea urchins } \\
\text { Maximum and most stable yield when fishing only piscivores and herbivores, but results in increased algae and } \\
\text { calcium carbonate deposition, and in decreased coral. }\end{array}$ \\
\hline $\begin{array}{l}\text { McClanahan } \\
\text { and Sala } \\
1997\end{array}$ & none & same as above & $\begin{array}{l}\text { Fishing all groups results in reef dominance by sea urchins } \\
\text { Fishing sea urchin results in fish yield decreasing by } 70 \% \\
\text { Fishing only piscivores results in more evenly structured ecosystem }\end{array}$ \\
\hline $\begin{array}{l}\text { Arias- } \\
\text { Gonzáles } \\
1998\end{array}$ & $\begin{array}{l}\text { comparison of an } \\
\text { unprotected site with two } \\
\text { partially protected areas }\end{array}$ & & $\begin{array}{l}\text { Trophic structure and biomass flows differ between protected and unprotected areas, and between habitats } \\
\text { In the unprotected area, biomass and biological production lower for piscivores and carnivores, and is larger for } \\
\text { herbivores, ectoparasites and zooplankton }\end{array}$ \\
\hline $\begin{array}{l}\text { Watson et al. } \\
2000\end{array}$ & No-take zone size & & $\begin{array}{l}\text { For all groups, marked increase in biomass after } 10 \text { years and maximum catch for } 10-15 \% \text { MPA } \\
\text { No further increase in biomass beyond } 15 \% \text { MPA } \\
\text { Optimal MPA size for both catch and biomass increases with mobility, until a maximum of } 20 \%\end{array}$ \\
\hline $\begin{array}{l}\text { Walters et al. } \\
1999\end{array}$ & $\begin{array}{l}\text { Example of an existing } \\
\text { partially protected area }\end{array}$ & & $\begin{array}{l}\text { For sessile species, pure trophic cascade within MPA } \\
\text { Fish movement and concentration of fishing effort at MPA boundary induces spillover of predators outside MPA } \\
\text { and prey accumulation at MPA boundary } \\
\text { MPA should be quite large to avoid boundary and behavioural effects : fewer large MPA better than many small }\end{array}$ \\
\hline
\end{tabular}


Accepted for publication in Fish and Fisheries

\begin{tabular}{|c|c|c|c|}
\hline & & & ones (except for sessile species) \\
\hline Walters 2000 & Same as above & & same as above plus locate MPA in places where dispersal and edge effects are limited \\
\hline $\begin{array}{l}\text { Pitcher et al. } \\
2002\end{array}$ & $\begin{array}{l}\text { AR within MPA system } \\
\text { MPA size from } 3 \text { to } 62 \% \\
\text { Number and size of AR } \\
\text { Fishing one AR out of } 3\end{array}$ & & $\begin{array}{l}\text { Biomass per size group increases with size of MPA/AR, particularly beyond } 30 \% \\
\text { Catch increases also for small and medium fish, but remains constant for large fish } \\
\text { Better recovery with MPA/AR system than with unprotected AR } \\
\text { Largest gain to fishery when AR and non-AR portions of MPA separated by non-protected area, because trophic } \\
\text { cascade reduced to fishery benefit } \\
\text { Small MPA cannot help avoid fishery collapse while large MPA are helpful to restore reef fisheries } \\
\text { (see economic consequences in Table 6) }\end{array}$ \\
\hline $\begin{array}{l}\text { Martell et al. } \\
(2005)\end{array}$ & $\begin{array}{l}\text { Closed areas per fleet: } \\
\text { EEZ closure, larger closure } \\
\text { to protect turtles }\end{array}$ & $\begin{array}{l}\text { Overall effort } \\
\text { doubles over } \\
50 \text { years }\end{array}$ & $\begin{array}{l}\text { Physical transport and behavioural response of fish to changes in community structure lead to different predictions } \\
\text { of MPA efficacy } \\
\text { MPA aimed at turtle protection does not allow population rebuilding }\end{array}$ \\
\hline $\begin{array}{l}\text { Beattie et al. } \\
2002\end{array}$ & $\begin{array}{l}\text { No-take zone size and } \\
\text { location under different } \\
\text { management objectives } \\
\text { Trawl exclusion }\end{array}$ & & $\begin{array}{l}\text { Optimal MPA size is } 2 \% \text { for maximum rent objective, } 37 \% \text { for conservation objective, and } 23 \% \text { for combined } \\
\text { objectives ( } 37 \% \text { when trawl excluded). } \\
\text { Protection of juveniles of main target species through proper location substantially increases biomass and yield. } \\
\text { When objectives include conservation, MPA larger than } 40 \% \text { lead to negative impact on target species due to } \\
\text { increased cannibalism } \\
\text { (see economic consequences in Table } 6 \text { ) }\end{array}$ \\
\hline Shin 2001 & No-take zone size & & MPA may be more efficient at maintaining catch and biodiversity \\
\hline
\end{tabular}


Accepted for publication in Fish and Fisheries

Table 6. Bioeconomic models investigating MPA impact : management scenarios investigated and main results.

\begin{tabular}{|c|c|c|}
\hline Reference & Management scenarios investigated & Main results for MPA management \\
\hline $\begin{array}{l}\text { Holland and } \\
\text { Brazee } 1996\end{array}$ & open access outside no-take zone & $\begin{array}{l}\text { Optimal reserve size greatly varies with overall effort level : at high levels, } 15-19 \% \\
\text { In heavily fished fisheries, catch increases under reserve. } \\
\text { Reserves provide benefits if catch or effort cannot be controlled }\end{array}$ \\
\hline Hannesson 1998 & open access outside no-take zone & $\begin{array}{l}\text { Little gain expected from MPA if fishing capacity and effort are not controlled } \\
\text { Conservation and optimal yield require large reserves (70-80\%) } \\
\text { Gain in catch would be compensated by increased fishing costs } \\
\text { Fishing season would be shorter in seasonal fisheries }\end{array}$ \\
\hline Sumaila 1998 & no-take zone & $\begin{array}{l}\text { Economic rent maximised for high transfer rates and large MPA (40-70\%) } \\
\text { Biological benefit of reserve in the case of recruitment failure }\end{array}$ \\
\hline Pitcher et al. 2002 & MPA and articificial reef system & $\begin{array}{l}\text { (see Table } 5 \text { for biological consequences) } \\
\text { Small MPA cannot prevent fishery collapse and decrease in economical rent } \\
\text { Large MPA restore valuable fisheries based on reef fish }\end{array}$ \\
\hline $\begin{array}{l}\text { Sanchirico and } \\
\text { Wilen } 2001 b\end{array}$ & Open access outside no-take zone & $\begin{array}{l}\text { Total catch will increase only under certain economic and biological (see Table 2) conditions : costs are low relative to prices } \\
\text { in the area to be closed, so that it is overexploited at equilibrium }\end{array}$ \\
\hline $\begin{array}{l}\text { Sanchirico and } \\
\text { Wilen 2001a }\end{array}$ & $\begin{array}{l}\text { Licence system outside no-take } \\
\text { zone }\end{array}$ & $\begin{array}{l}\text { License price rises until equal to expected production rent. It is an indicator of the economic benefit of MPA to the fishery } \\
\text { (opportunity cost) } \\
\text { Double payoff situations are more likely to occur in the case of initial overexploitation and moderate dispersal. Benefit }\end{array}$ \\
\hline
\end{tabular}




\begin{tabular}{|c|c|c|}
\hline & & resulting from no-take zone depends on siting \\
\hline Anderson 2002 & Open access outside no-take zone & $\begin{array}{l}\text { For any initial stock size and number of vessels, harvest increases with reserve size because fishable area smaller and } \\
\text { spillover due to density-dependent migration } \\
\text { Economic equilibrium per vessel when no reserve and stock equals carrying capacity, or under certains conditions with a } \\
\text { reserve }\end{array}$ \\
\hline Beattie et al. 2002 & $\begin{array}{l}\text { No-take zone } \\
\text { trawl exclusion }\end{array}$ & $\begin{array}{l}\text { (see Table } 5 \text { for biological consequences) } \\
\text { Any MPA solely based on conservation objectives has negative impact on all fleets } \\
\text { Policy options that consider economic objectives alone or combined with conservation objectives induce rent increases for } \\
\text { some fleets under any MPA design. The optimal MPA would correspond to a size of } 25-40 \% \text { of the North Sea area and } \\
\text { would be located in the South and East. } \\
\text { Trawl exclusion results in small to large benefits for all other fleets and for conservation }\end{array}$ \\
\hline $\begin{array}{l}\text { Boncoeur et al. } \\
2002\end{array}$ & $\begin{array}{l}\text { Open access outside no-take zone } \\
\text { Ecotourism }\end{array}$ & $\begin{array}{l}\text { Immediate trade-off between safe stock level and economic benefit } \\
\text { Interactions between stocks reduce fishery benefits but offer opportunity for ecotourism } \\
\text { Larger size needed to favour ecotourism }\end{array}$ \\
\hline Hannesson 2002 & open access outside no-take zone & $\begin{array}{l}\text { Under MPA, biomass increases and catch decreases. In a stochastic model, MPA reduces catch variance. Biomass increases } \\
\text { are mitigated by large migration rates }\end{array}$ \\
\hline Sumaila 2002 & open access outside no-take zone & $\begin{array}{l}\text { Optimal size in all cases is } 60-70 \% \\
\text { Facing recruitment failure, joint management induces better resource rebuilding and higher discounted profits with MPA }\end{array}$ \\
\hline
\end{tabular}




\section{Accepted for publication in Fish and Fisheries}

Table 7. Ecological and fisheries-related effects expected from the establishment of an MPA, and estimated ability of each model type to address each effect (N : not appropriate, $*$ : low, ${ }^{* *}$ : medium, $* * *$ : good). Habitat-related effects were not considered because no models account for habitat. Multiple species models are those including several populations with no interspecific relationships, like those used for mixed fisheries. SSB stands for Spawning Stock Biomass.

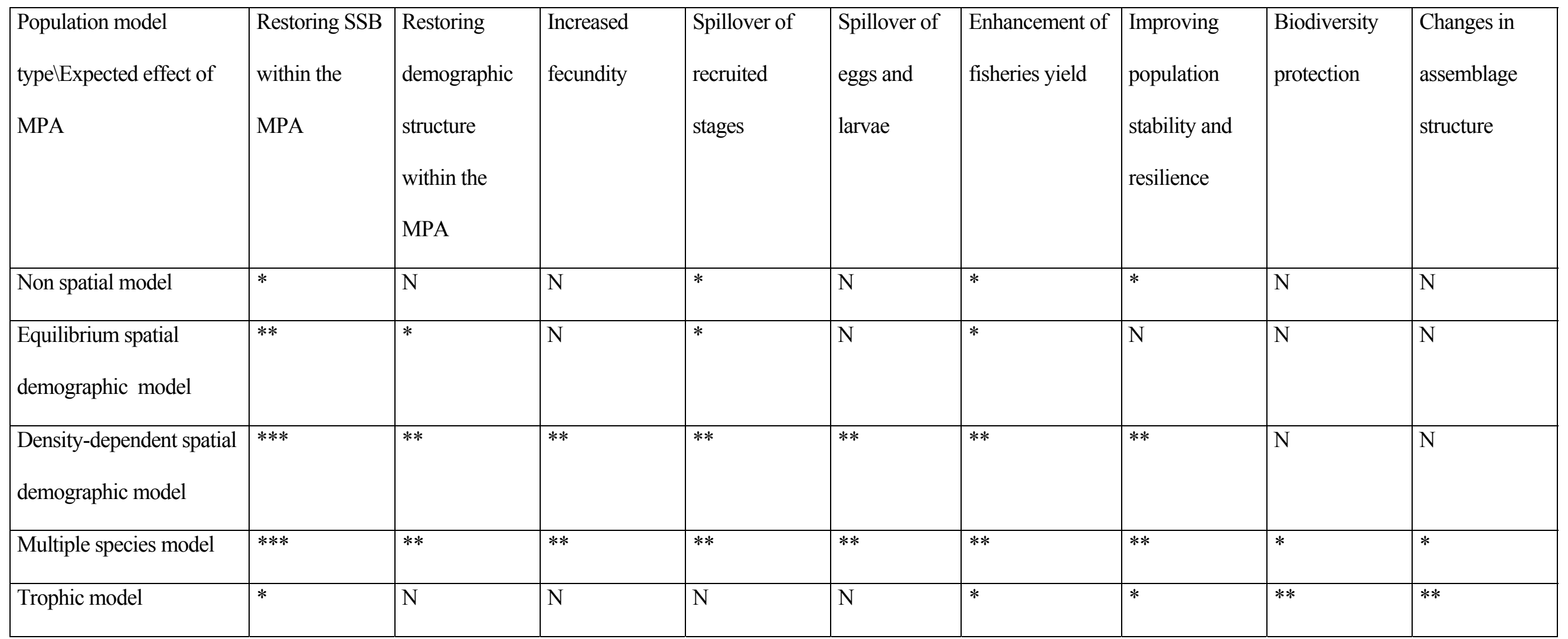


Accepted for publication in Fish and Fisheries

Table 8. Parameterization of fishing effort. Gear parameter may be quantitative (e.g. mesh size), or categorical (e.g. hook type).

\begin{tabular}{|c|c|c|}
\hline $\begin{array}{l}\text { Effort-related model } \\
\text { entity (notation) }\end{array}$ & Parameter definition & $\begin{array}{l}\text { Parameter notation and dimension } \\
\text { (when needed for equations) }\end{array}$ \\
\hline Fleet $(f)$ & $\begin{array}{l}\text { Number of trips each month } \\
\text { Maximum time spent at sea each month }\end{array}$ & $\begin{array}{l}\operatorname{NbTrips}_{\text {month }}(f) \\
\operatorname{MaxTime}_{\text {month }}^{\text {sea }}(f)\end{array}$ \\
\hline Strategy (str) & $\begin{array}{l}\text { Number of fishing units per fleet } \\
\text { Proportion of fishing units practising a given } \\
\text { métier each month }\end{array}$ & $\begin{array}{l}\operatorname{NbFU}(\text { str }, f) \\
\operatorname{PropStr}(s t r, m, t)\end{array}$ \\
\hline Métier $(m)$ & $\begin{array}{l}\text { Gear used (one) } \\
\text { Gear parameter value } \\
\text { Seasons and zones } \\
\text { Travel time per trip at season } \\
\text { List of target species } \\
\text { Target factor per species at season } \\
\text { Number of fishing operations per day }\end{array}$ & $\begin{array}{l}\bar{T}_{\text {travel }}(m, t) \\
\sigma_{p o p}(m, t) \\
N b O p_{d a y}(m)\end{array}$ \\
\hline Gear $(g)$ & $\begin{array}{l}\text { List of catchable species } \\
\text { Effort unit } \\
\text { Standardization factor } \\
\text { Technical parameter } \\
\text { Range of values for parameter } \\
\text { Selectivity function per catchable species }\end{array}$ & $\begin{array}{l}\rho_{\text {std }}(g) \\
\operatorname{Sel}_{p o p}(\bar{I}(c), g)\end{array}$ \\
\hline
\end{tabular}


Accepted for publication in Fish and Fisheries

Table 9. Biological parameters of populations considered in the example. The last class of each population is a plus-group. Natural mortality coefficients were then transformed to monthly values to be used in equations 2 and 11. Catchabilities correspond to $\bar{q}_{p o p}(c, t)$ in equation (A.2.4) of Appendix 2.

\begin{tabular}{|l|l|l|}
\hline \multicolumn{1}{|c|}{ Parameter } & \multicolumn{1}{|c|}{ Population 1 } & \multicolumn{1}{|c|}{ Population 2 } \\
\hline Number of age classes & 3 & 4 \\
\hline Mean length $(\mathrm{cm})$ & $(5,20,30)$ & $(10,30,50,90)$ \\
\hline Mean weight $(\mathrm{kg})$ & $(0.1,0.5,0.8)$ & $(0.3,1.2,1.9,2.5)$ \\
\hline Natural mortality $\left(\mathrm{yr}^{-1}\right)$ & $(0.8,0.2,0.2)$ & $(0.8,0.2,0.2,0.2)$ \\
\hline Age at maturity & 1 & 2 \\
\hline Fecundity rate (ind $\left.{ }^{-1}\right)$ & $(0,0.5,2)$ & $(0,0,2,3)$ \\
\hline Temporal distribution of reproduction $\left(p_{\text {repro }}\right)$ & $(0.25,0.5,0.25)$ & $(0.25,0.5,0.25)$ \\
\hline Temporal distribution of recruitment $\left(p_{\text {rec }}\right)$ & $(0.25,0.5,0.25)$ & $(0.5,0.5)$ \\
\hline Catchability $(* 10 \mathrm{e} 6)$ from January to April & $(0,1.25,2.5)$ & $(0,1.25,2.0,2.5)$ \\
\hline Catchability $(* 10 \mathrm{e} 6)$ from May to December & $(0,1.25,2.5)$ & $(0.5,1.25,2.0,2.5)$ \\
\hline Initial population sizes & $(0,10 \mathrm{e} 8,10 \mathrm{e} 6)$ & $(0,10 \mathrm{e} 8,10 \mathrm{e} 6,10 \mathrm{e} 4)$ \\
\hline
\end{tabular}


Table 10. Management scenarios considered in the example and consequences on fishing effort allocation. F, pop1 and pop2 respectively stand for fishing mortality, population 1 and population 2. Zones are displayed in Fig. 3.

\begin{tabular}{|c|c|c|c|}
\hline Management scenario & Objective & Consequences on effort & $\begin{array}{c}\text { Expected consequences on } \\
\text { populations }\end{array}$ \\
\hline $\begin{array}{l}\text { closure of zg3 between January } \\
\text { and April (denoted MPA=ZG3 } \\
\text { on Figs 6-7) }\end{array}$ & $\begin{array}{l}\text { protect reproduction } \\
\text { of pop } 1\end{array}$ & $\begin{array}{r}\text {-métier } 1 \text { reallocates effort to the rest of zm1 } \\
\text {-métier } 2 \text { not affected }\end{array}$ & $\begin{array}{l}\text {-decreased } \mathrm{F} \text { for pop } 1 \\
\text {-increased } \mathrm{F} \text { for pop2 (particularly } \\
\text { for immatures) }\end{array}$ \\
\hline $\begin{array}{l}\text { permanent closure of zg3 (see } \\
\text { results on Fig. 5) }\end{array}$ & $\begin{array}{l}\text { protect all stages of } \\
\text { pop1 }\end{array}$ & $\begin{array}{l}\text {-métier } 1 \text { reallocates effort to the rest of zm1 } \\
\text {-métier } 2 \text { not affected }\end{array}$ & $\begin{array}{l}\text {-decreased } F \text { for pop } 1 \\
\text {-increased } F \text { for pop2 }\end{array}$ \\
\hline $\begin{array}{l}\text { closure of zg2 between February } \\
\text { and April (denoted MPA=ZG2 } \\
\text { on Figs 6-7) }\end{array}$ & $\begin{array}{l}\text { protect reproduction } \\
\text { of pop } 2\end{array}$ & $\begin{array}{l}\text {-métier } 1 \text { not affected } \\
\text {-métier } 2 \text { reallocates effort to the rest of zm3 }\end{array}$ & $\begin{array}{l}\text {-no consequence for pop1 } \\
\text {-decreased } \mathrm{F} \text { for pop2 }\end{array}$ \\
\hline $\begin{array}{l}\text { closure of } \mathrm{zg} 1 \text { from May to } \\
\text { December (denoted MPA=ZG1 } \\
\text { on Figs 6-7) }\end{array}$ & $\begin{array}{l}\text { avoid incidental } \\
\text { catch of juveniles of } \\
\text { pop } 2\end{array}$ & $\begin{array}{l}\text {-métier } 1 \text { reallocates effort to the rest of zm1 } \\
\text {-métier } 2 \text { reallocates effort to the rest of zm3 }\end{array}$ & $\begin{array}{l}\text {-decreased } \mathrm{F} \text { for pop1 } \\
\text {-cancel catch of pop } 2 \text { by métier } 1\end{array}$ \\
\hline TAC on pop2 & fishing & -when TAC reached, métier 2 reallocates effort to métier 1 , & -increased F for pop1 \\
\hline
\end{tabular}




\begin{tabular}{|c|c|c|c|}
\hline (denoted TACpop2 on Figs 6-7) & pressure on pop2 & and métier 1 discards pop 2 catch & -decreased $\mathrm{F}$ for pop2 \\
\hline $\begin{array}{l}\text { TAC on pop2 and closure of } \\
\text { zg3from January to April } \\
\text { (denoted TACpop2+MPA=ZG3 } \\
\text { on Figs 6-7) }\end{array}$ & $\begin{array}{l}\text { reduce fishing } \\
\text { pressure on pop2 and } \\
\text { protect reproduction } \\
\text { of pop1 }\end{array}$ & $\begin{array}{l}\text {-From January to April, métier } 1 \text { reallocates effort to the rest } \\
\text { of zm1. From May to December, métier } 1 \text { reallocates effort to } \\
\mathrm{zm} 1 \\
\text {-when TAC reached, métier } 2 \text { reallocates effort to métier } 1 \text {, } \\
\text { and métier } 1 \text { discards pop2 }\end{array}$ & $\begin{array}{l}\text {-decreased F for pop1 } \\
\text {-decreased F for pop2 }\end{array}$ \\
\hline
\end{tabular}




\section{FIGURE CAPTIONS}

Figure 1. Example of zones considered in the model : a population zone (grey), a metier zone (vertical lines) and a management zone (horizontal lines). A métier is a fishing activity (see subsection 3.3). At any time step, fisheries dynamics depends on the spatial overlaps between zones.

Figure 2. Chronology of demographic processes during a given month. $\varepsilon$ denotes an arbitrarily small time interval to indicate that change of class, migrations, reproduction and recruitment are assumed to take place instantaneously at the beginning of the time step. Change of class occurs through aging in the case of agestructured dynamics, and through individual growth in the case of stage-structured dynamics.

Figure 3. Description of spatial processes of population, exploitation and management model: migration, reproduction and recruitment of the modelled populations (top), métier zones (medium) and management zones (bottom) considered.

Figure 4. Biomass and catch trajectories obtained in the absence of policy (filled line), and under the seasonal closure of zg3 (4cells) (dotted line, Table 10 and Fig. 3).

Figure 5. Impact of MPA size for the closure of zg3 (Fig. 3, bottom) from May to December. Sizes investigated ranged from 2 to 5 cells (Fig. 3, bottom). F/I biomass ratio corresponds to December biomass in year 10 divided by December biomass in the second year of the simulation. F/I catch ratio corresponds to cumulated catch in the last year of the simulation divided by cumulated catch in the second year of the simulation. w/wo biomass ratio is equal to December biomass in year 10 under a given policy divided by December biomass in year 10 in the absence of policy. w/wo catch ratio is total catch in year 10 under a given policy divided by the total catch in the absence of policy. The diamon-shaped point corresponds to a permanent closure of zg3 (3 cells). 
Figure 6. Biomass and catch ratios obtained for the management scenarios of Table 10. Biomass and catch ratio are the same as in Fig. 5. B1, C1, B2 and C2 respectively denote the biomass and catch ratios for populations 1 and 2.

Figure 7. Biomass and catch ratios of population 2 obtained for several values of TAC. Biomass and catch ratio are the same as in Fig. 5.

Figure 8. Landings and discards resulting from a policy with a TAC of $210 \mathrm{kt}$. Landings are displayed using a full line, and discards with a dotted line. 
Figure 1

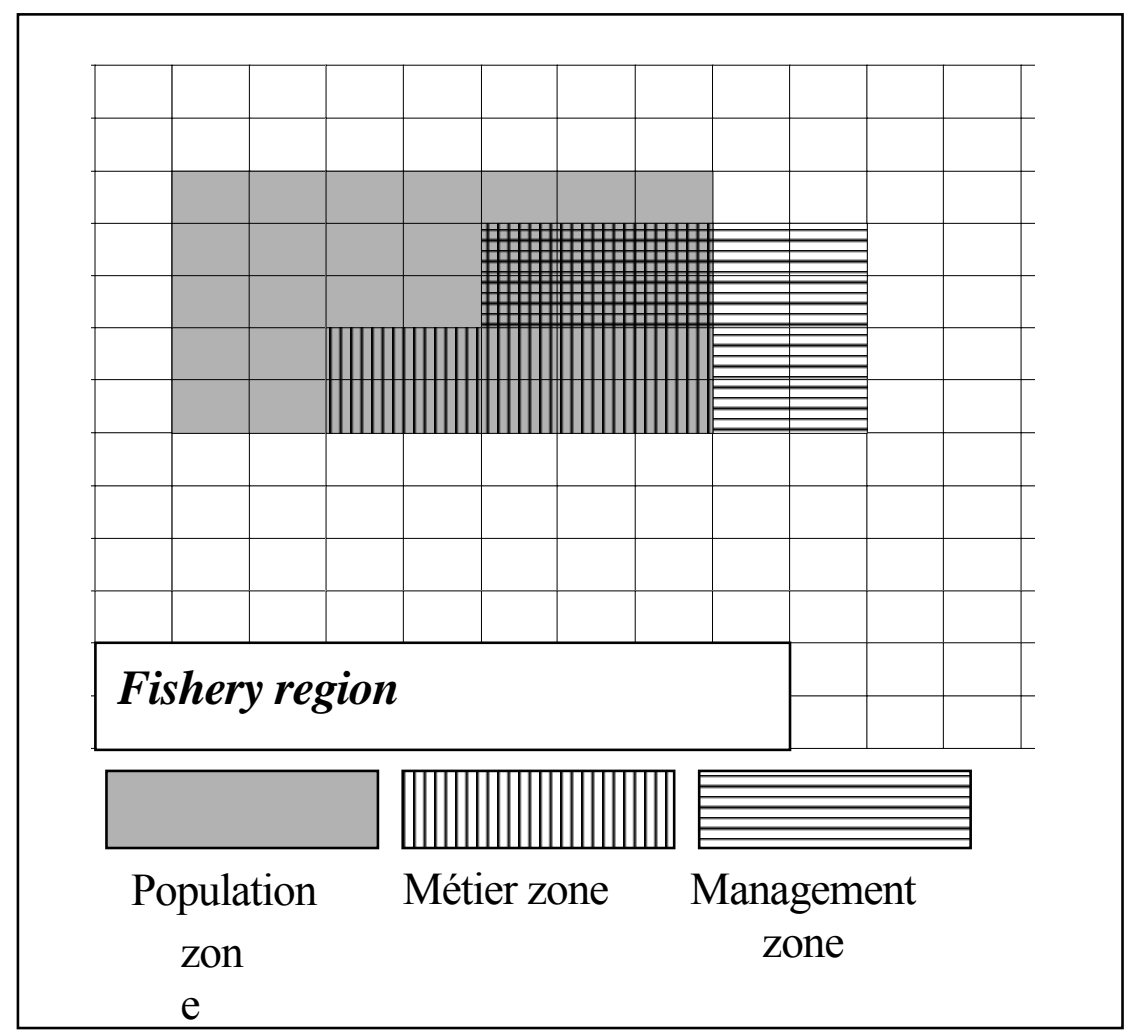


Figure 2

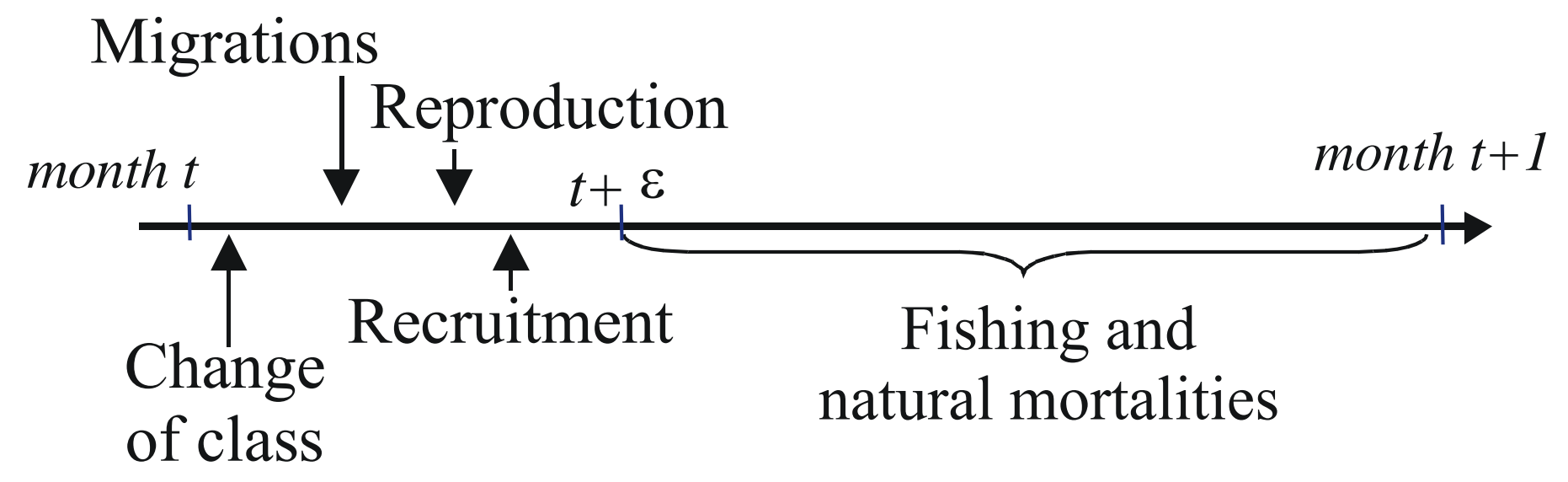



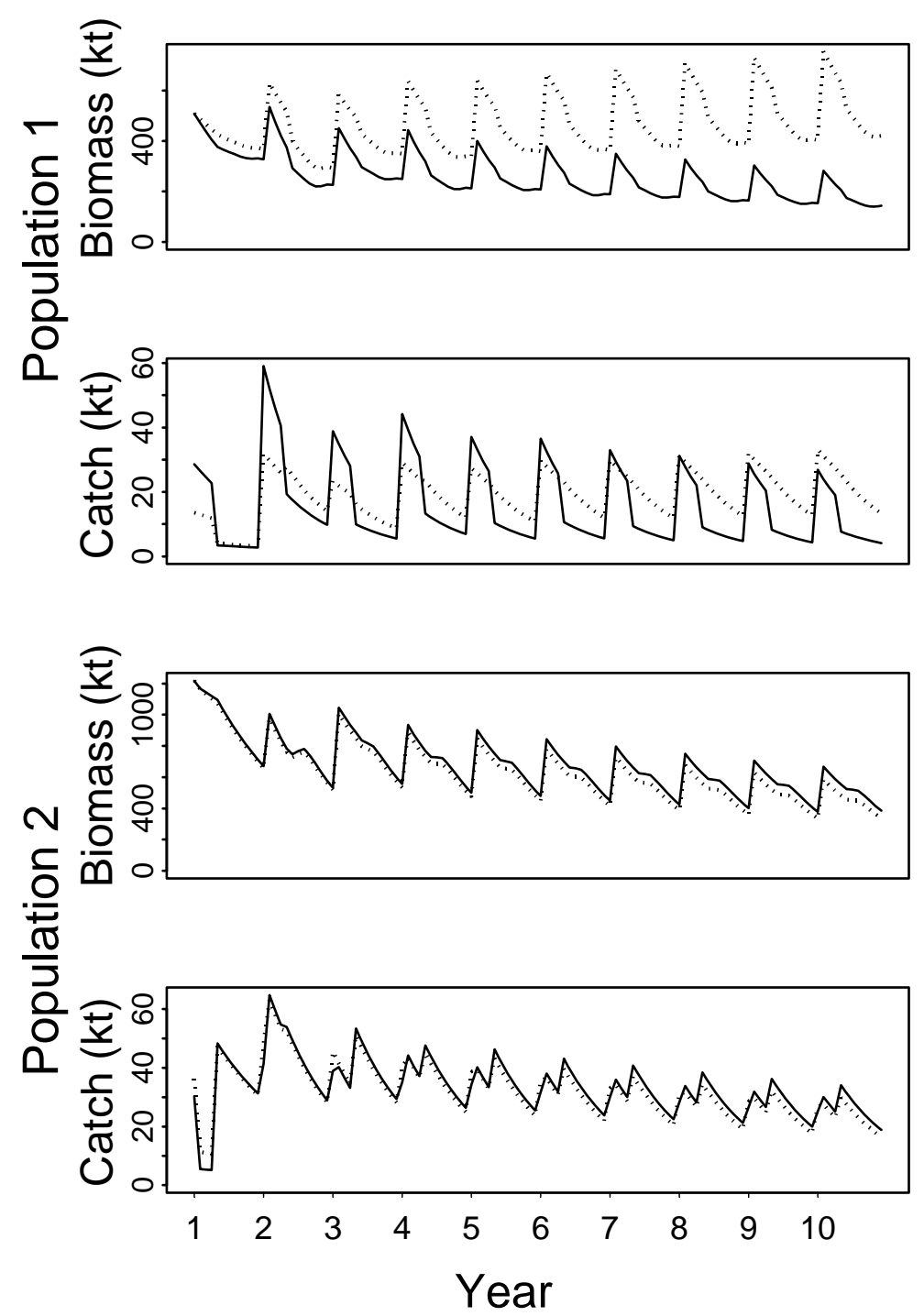

Figure 4 

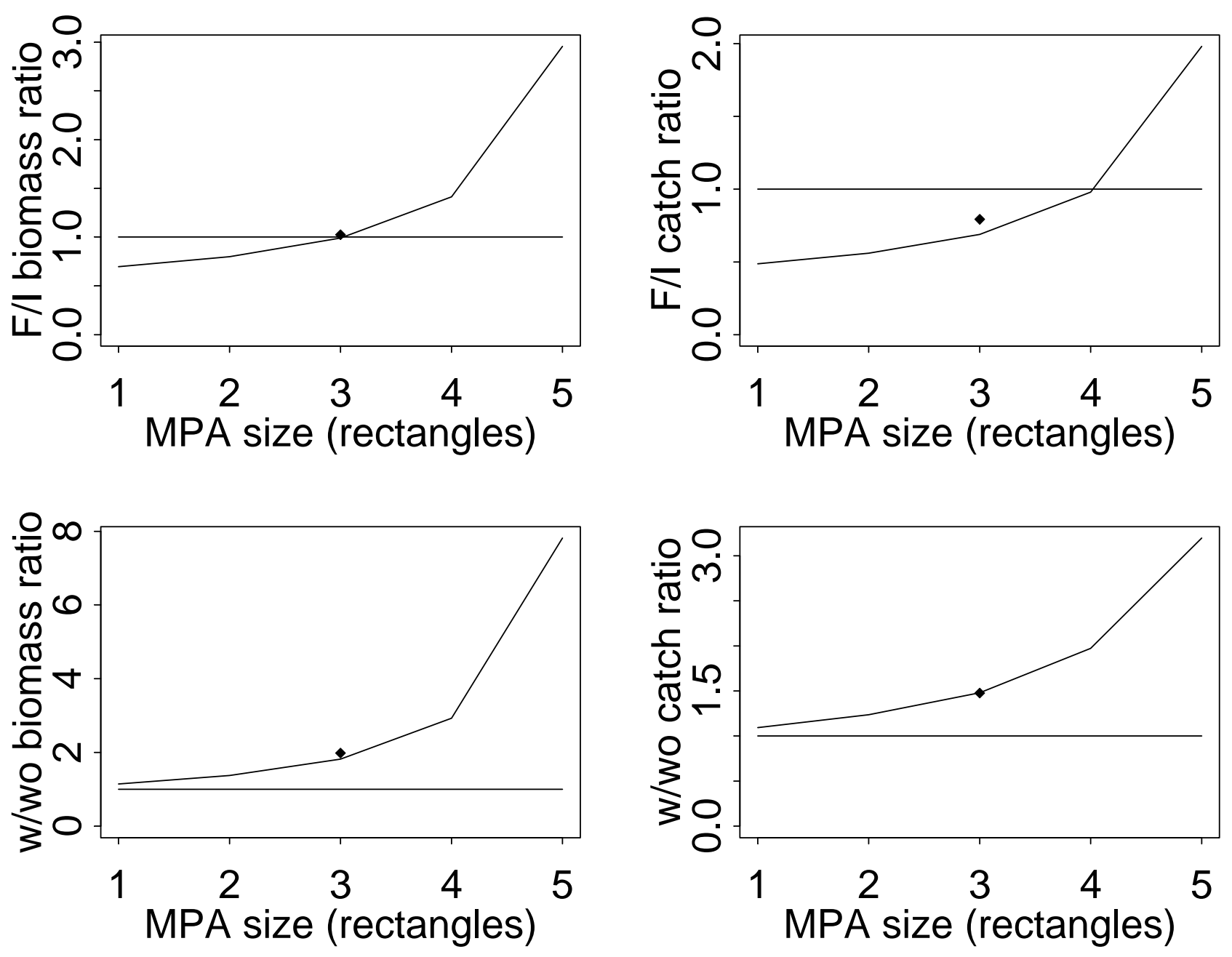

Figure 5 

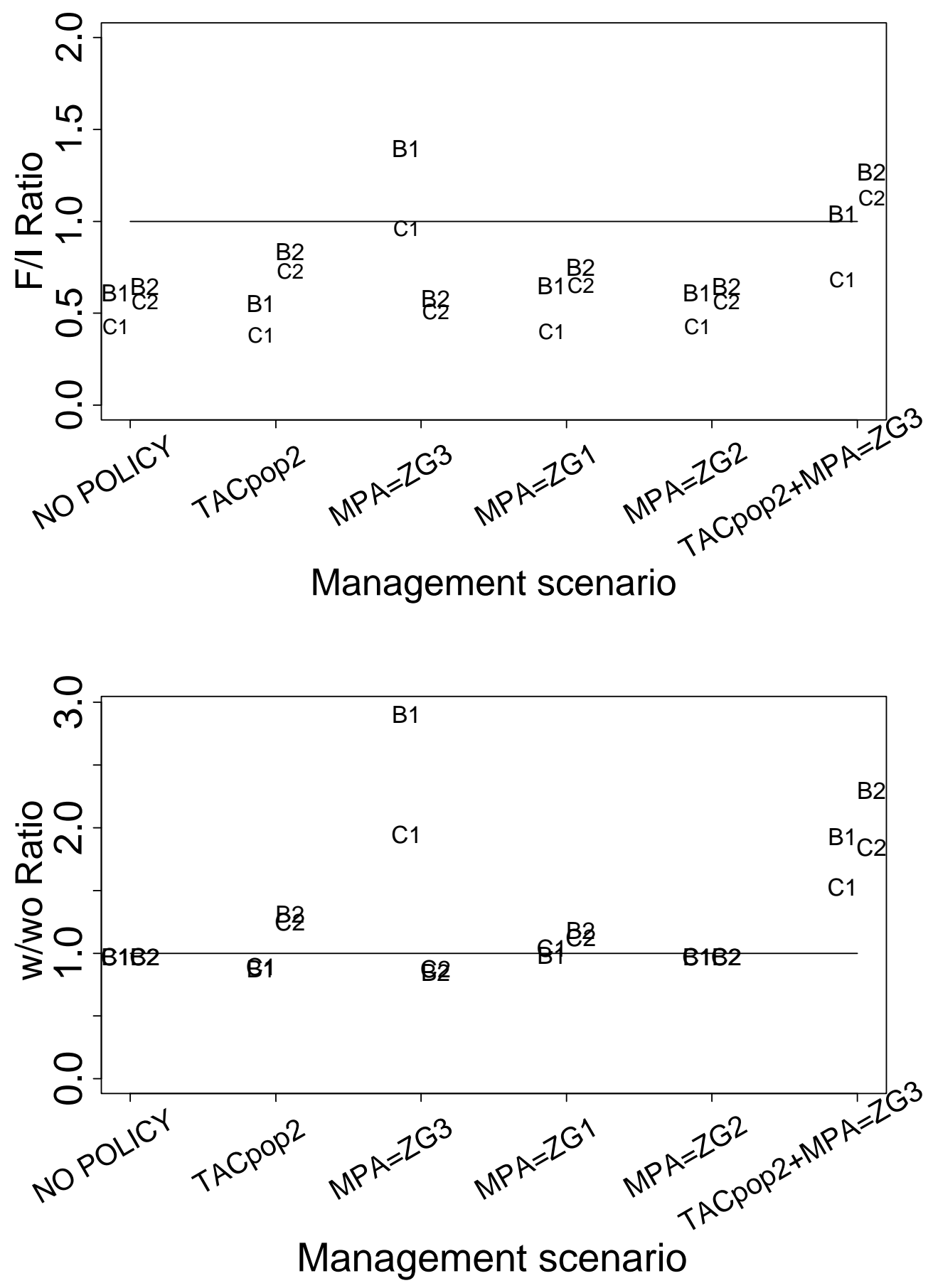

Figure 6 
Figure 7
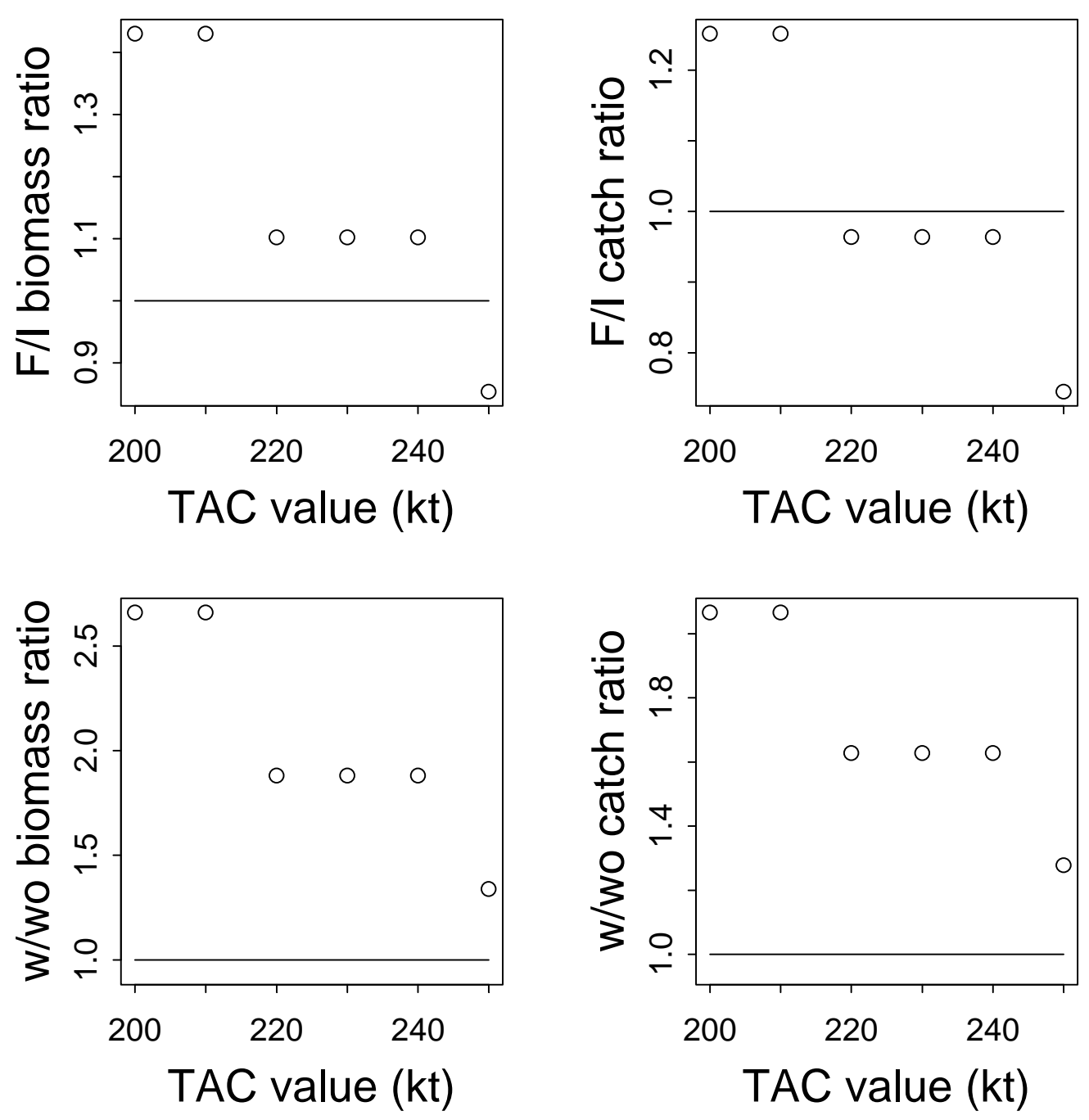
Figure 8

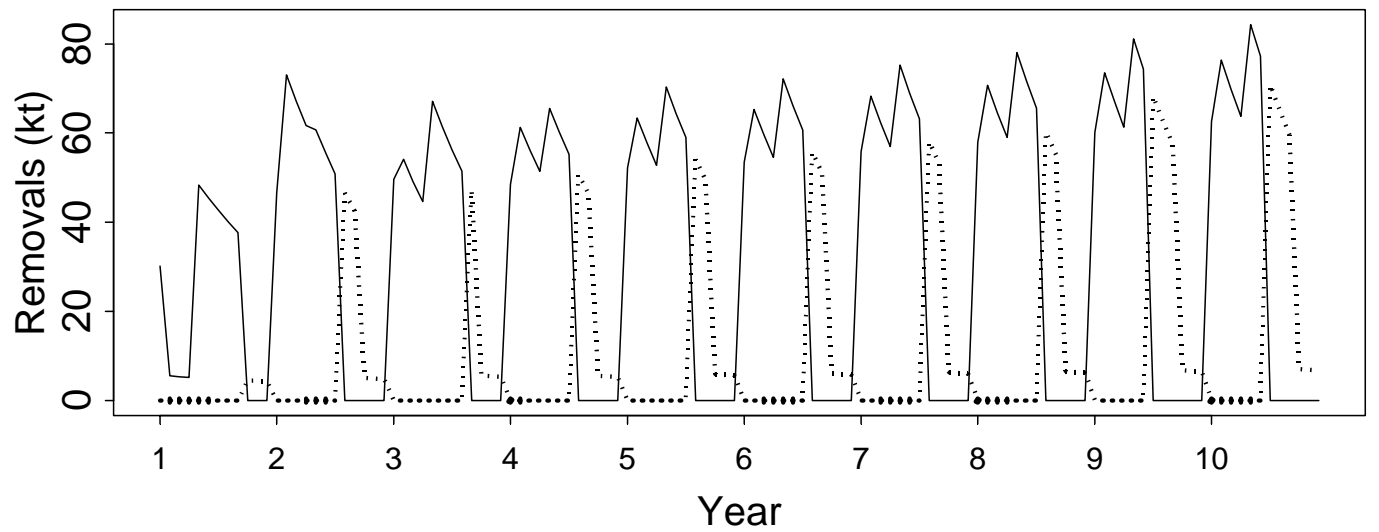

